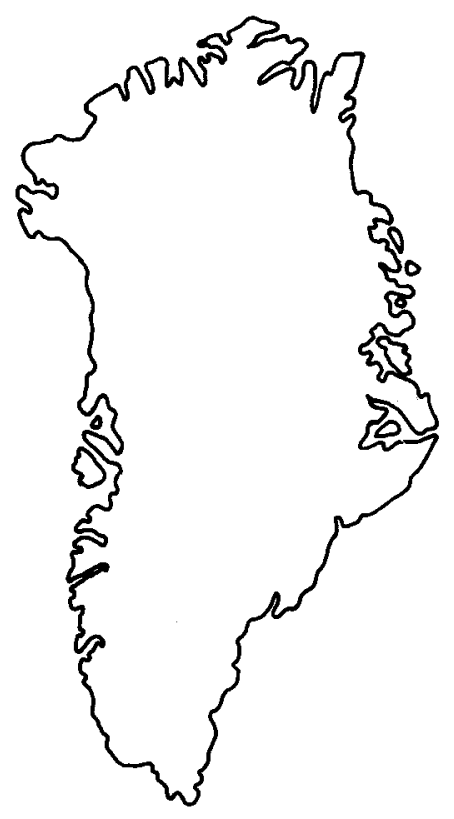

\title{
Systematics and phylogenetics of polymeroid trilobites from the Henson Gletscher and Kap Stanton formations (Middle Cambrian), North Greenland
}

\author{
Loren E. Babcock
}

\begin{abstract}
Middle Cambrian strata of northernmost North Greenland contain polymeroid trilobites of Laurentian and Baltic aspect. Trilobites of Laurentian aspect were found primarily in lime mudstone and wackestone representing shelf lithofacies, whereas trilobites of Baltic aspect were found primarily in lime mudstone representing outer shelf lithofacies. Rare packstone beds in the deeper water lithofacies contain assemblages of mixed aspect.

Thirty-three polymeroid species, some in open nomenclature, are described from the Henson Gletscher and Kap Stanton formations of Nyeboe Land and Peary Land. Of the 21 genera identified, one eodiscid, Costadiscus, is new. Six species, Bathyuriscus concavus, Costadiscus minutus, Dasometopus groenlandicus, Elyx trapezoidalis, Kootenia nodosa, and Opsidiscus longispinus, are new.

Cladistic analysis indicates that eodiscid trilobites are a paraphyletic and possibly polyphyletic group that probably arose from polymeroid ancestors through mosaic heterochrony. The Polymerida, as previously applied, is also interpreted to be a paraphyletic group. Small size in eodiscids was achieved independently from that in agnostoids and condylopygids, probably through progenesis. Loss of eyes in some eodiscids evidently occurred in more than one evolutionary lineage. Available evidence suggests that agnostoids and eodiscids did not share a close common ancestor.

Cladistic analysis of Xystridura, Galahetes, Lermontovia, Bergeroniellus, Paradoxides, Anopolenus, Clarella, and Centropleura indicates that these trilobites are part of one monophyletic group, the family Paradoxididae. Two smaller clades within the Paradoxididae are recognised; these are the subfamilies Xystridurinae, with Xystridura and Galahetes, and Paradoxidinae with all the other paradoxidid genera. Both paedomorphic and peramorphic processes are inferred to have been important in the evolution of the paradoxidid trilobites.
\end{abstract}

L. E. B., Department of Geological Sciences and Byrd Polar Research Center, The Ohio State University, Columbus, Ohio 43210, U.S.A.

New occurrences of Middle Cambrian polymeroid trilobites from the Henson Gletscher and Kap Stanton formations of Nyeboe Land, and the Kap Stanton Formation of Peary Land, North Greenland (Fig. 1), are documented here. Trilobites from these areas were collected by staff of the Geological Survey of Greenland (GGU) and are relatively abundant and diverse (Table 1). The biofacies and biogeographic significance of these trilobites, and their implications for palaeo-oceanographic and platetectonic reconstructions are addressed in an accompanying paper (Babcock, 1994). Some of the fossils described here were the basis for preliminary studies by Fletcher $e t$ al. (1988), Babcock \& Robison (1989), and Robison \& Babcock (1990). Collections range in age from the Glossopleura Biochron to the Lejopyge laevigata Biochron.
Trilobites from the Glossopleura Assemblage-zone are entirely polymeroids, whereas those from the Ptychagnostus gibbus, $P$. atavus, and Lejopyge laevigata intervalzones are mixed polymeroids and agnostoids. The agnostoid trilobites are described in an accompanying paper (Robison, 1994).

Middle Cambrian strata of North Greenland contain polymeroid trilobites of both Laurentian and Baltic aspect. Most previously described polymeroids are of Laurentian aspect (Poulsen, 1927; Poulsen, 1964; Palmer \& Peel, 1981; Robison, 1988), which accords with the interpretation (Scotese et al., 1979; Scotese \& McKerrow, 1990) that Greenland and North America were united in a single Cambrian continent, Laurentia (see also Peel \& Christie, 1982; Higgins et al., 1991). Taxa of Baltic 

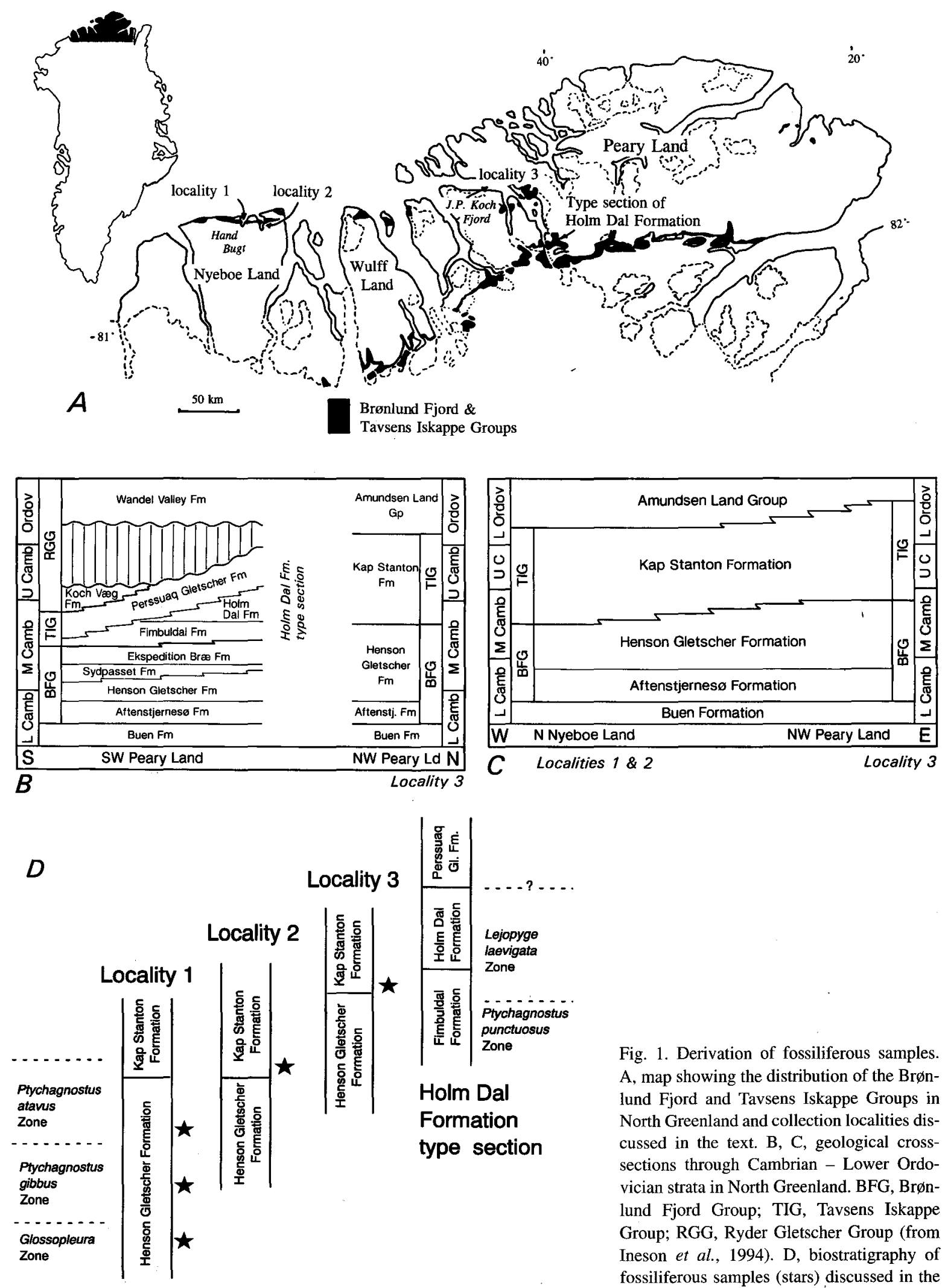

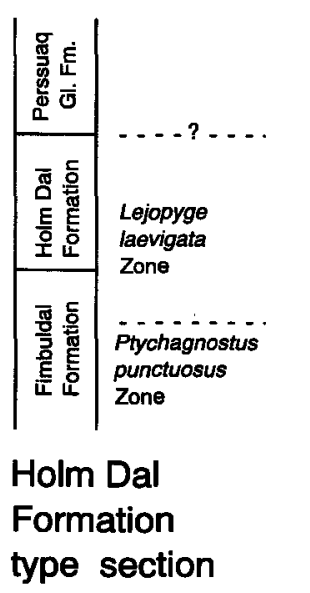

Fig. 1. Derivation of fossiliferous samples. A, map showing the distribution of the Brønlund Fjord and Tavsens Iskappe Groups in North Greenland and collection localities discussed in the text. B, C, geological crosssections through Cambrian - Lower Ordovician strata in North Greenland. BFG, Brønlund Fjord Group; TIG, Tavsens Iskappe Group; RGG, Ryder Gletscher Group (from Ineson et al., 1994). D, biostratigraphy of fossiliferous samples (stars) discussed in the text. 
aspect are present along the northern coast of Greenland in Nyeboe Land and Peary Land (Poulsen, 1969; Fletcher et al., 1988; Babcock \& Robison, 1989; Babcock, 1990a; Robison \& Babcock, 1990). Although polymeroids of Baltic aspect have been previously described from autochthonous or parautochthonous rocks of Laurentia (Howell, 1937; Hutchinson, 1952; Shaw, 1966; Rasetti, 1967; Palmer \& Stewart, 1968; Babcock, 1990a), new specimens from North Greenland are the first from relatively undisturbed stratigraphic sequences. Polymeroids described here (Table 1) and associated agnostoids described by Robison (1994) are preserved in shelf lithofacies that represent native terranes (as defined by Keppie, 1989) of the Laurentian palaeocontinent. This new material significantly increases the record of Cambrian trilobites from the Innuitian margin of Laurentia.

Together with taxa described recently from the upper Middle Cambrian Holm Dal Formation (Robison, 1988), the new material provides important new data on the biogeography of Middle Cambrian trilobites. Differences between Middle Cambrian polymeroid assemblages of Laurentian and Baltic aspect are inferred to have been controlled by, or covaried with, water temperature and are not necessarily due to endemism developed around distantly separated cratons (Babcock, 1994).

\section{Geologic setting and stratigraphy}

Lower Palaeozoic rocks crop out along the coast of North Greenland in a band up to $250 \mathrm{~km}$ wide, forming the continuation of the Franklinian Basin of the Canadian Arctic Islands (Higgins et al., 1991; Surlyk, 1991). The northernmost part of this outcrop belt lies within the east-west trending North Greenland fold belt, which consists of Upper Proterozoic? to Silurian sedimentary rocks that were deformed and metamorphosed primarily during the Ellesmerian orogeny of Devonian age (Dawes, 1971, 1976; Dawes \& Soper, 1973; Higgins et al., 1981, 1991; Surlyk, 1991). Localised structural overprinting occurred during the Eurekan orogeny of Cretaceous to Tertiary age (Dawes, 1971, 1976; Higgins et al., 1981; Surlyk, 1991). The North Greenland fold belt is a continuation of the Innuitian orogenic system of arctic Canada (Dawes, 1976; Higgins et al., 1991).

The stratigraphy and evolution of the Cambrian shelf, slope, and basin in North Greenland have been discussed by Ineson $(1980,1985,1988)$, Ineson \& Peel (1987, unpublished), Peel (1982), Peel \& Christie (1982), Surlyk \& Ineson (1987), Higgins et al. (1991), Surlyk (1991), and a summary by Ineson et al. (1994) is published together with this paper.

Two major depositional environments are represented
Table 1. Classification of polymeroid trilobites identified from the Henson Gletscher and Kap Stanton formations

\author{
'Polymerida' \\ Family Anomocaridae \\ Anomocarina excavata (Angelin) \\ Family Conocoryphidae \\ Dasometopus groenlandicus n. sp. \\ Elyx trapezoidalis $\mathrm{n}$. $\mathrm{sp}$. \\ Hartshillia inflata (Hicks)
}

Family Corynexochidae Corynexochus? sp.

Family Dolichometopidae Bathyuriscus concavus n. sp. Bathyuriscus sp. Glossopleura walcotti Poulsen

Family Dorypygidae Kootenia nodosa $\mathrm{n}$. sp. Olenoides sp. Olenoides cf. $O$. convexus Rasetti

Family Menomoniidae Bolaspidella sp.

Family Ogygopsidae Ogygopsis klotzi (Rominger)

Family Paradoxididae Centropleura loveni (Angelin) Centropleura angelini? Westergård

Family Solenopleuridae Parasolenopleura aculeata (Angelin) Solenopleura bucculenta Grönwall Solenopleurella transversa? Rasetti

Family Zacanthoididae Zacanthoides $\mathrm{sp}$.

Family unassigned Elrathia sp. Syspacephalus sp. 1 Syspacephalus sp. 2 Syspacephalus sp. 3 Eodiscus scanicus (Linnarsson) Costadiscus minutus n. gen., n. sp. Opsidiscus longispinus $\mathrm{n}$. $\mathrm{sp}$. Undetermined corynexochoid Undetermined ptychoparioid 1 Undetermined ptychoparioid 2 Undetermined ptychoparioid 3 Undetermined ptychoparioid 4 Undetermined ptychoparioid 5 Undetermined ptychoparioid 6

by Cambrian rocks of North Greenland (Higgins et al., 1991; Ineson et al., 1994). An extensive carbonate shelf lay to the south in the area near the margin of the presentday Inland Ice, and a deeper water trough was in an area 


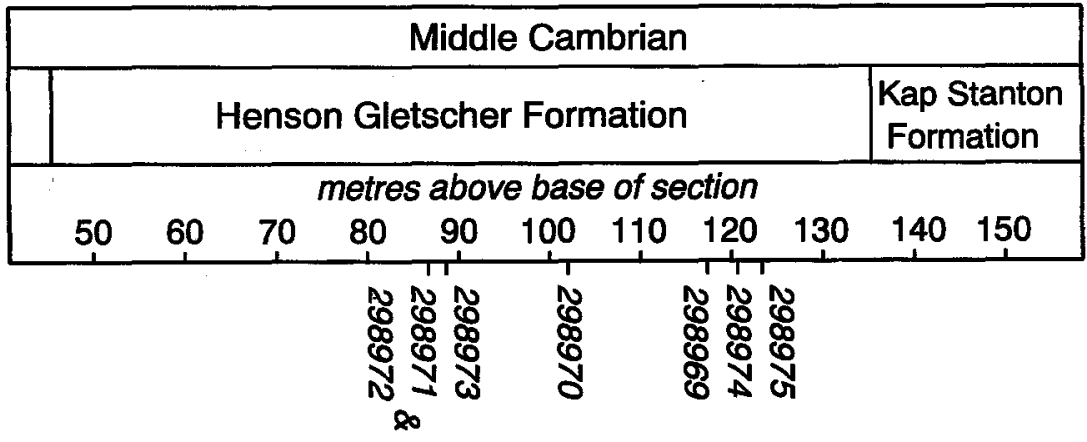

Glossopleura walcotti Undet. ptychoparioid 1 Undet. ptychoparioid 5 Kootenia nodosa Ogygopsis klotzi

Bathyuriscus sp. Bolaspidella sp.

Elrathia sp. Olenoides sp. Syspacephalus sp. 2 Zacanthoides sp. Undet. corynexochoid Undet. ptychoparioid 2 Undet. ptychoparioid 3 Undet. ptychoparioid 4 Costadiscus minutus Eodiscus scanicus Hartshillia inflata Parasolenopleura aculeata Syspacephalus sp. 1 Undet. ptychoparioid 6
Fig. 2. Stratigraphic distribution of polymeroid trilobites in GGU collections from the Henson Gletscher Formation in Hand Bugt, Nyeboe Land (locality 1, Fig. 1). The base of the Henson Gletscher Formation is $46 \mathrm{~m}$ above the base of the measured section. GGU collections 298971 to 298973 are from the Glossopleura Assemblage-zone; GGU collection 298970 is from the Ptychagnostus gibbus Interval-zone; and GGU collections 298969,298974 , and 298975 are from the Ptychagnostus atavus Interval-zone. to the present-day north. The relationship between the shelf and trough was complex, with the margin being largely fault controlled. Cambrian shelf deposits reach a maximum thickness of about $1.5 \mathrm{~km}$ and the basinal deposits are 2 to $3 \mathrm{~km}$ thick.

Rocks containing trilobites reported here have been only moderately disrupted structurally (Fletcher $e t$ al., 1988; also see Soper \& Higgins, 1985; Higgins et al., 1991). Stratigraphic relationships show that they were deposited mainly in outer shelf environments. Correlation of strata containing the fossils described herein along well-exposed fjord walls to undeformed sequences in the south, deposited higher on the shelf, indicates that these outer shelf rocks are autochthonous, not allochthonous (Higgins et al., 1991; Ineson et al., 1994). Palaeontologic evidence, in the form of mixed assemblages of trilobites from warm-water and cool-water biofacies near the shelf margin (Babcock, 1991, 1994), supports that interpretation.

\section{Lithostratigraphy and fossil localities}

New polymeroid trilobites have been collected from two localities in Nyeboe Land and one in Peary Land, North Greenland (Fig. 1). Collections were obtained from the middle and upper parts of the Henson Gletscher Formation of the Bronlund Fjord Group and the basal beds of the Kap Stanton Formation of the Tavsens Iskappe Group, which locally overlies the Henson Gletscher Formation (Fig. 1).

The Kap Stanton Formation is formally defined in an 


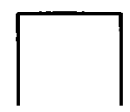

怘

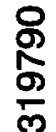

Bathyuriscus concavus

Corynexochus? sp.

Costadiscus minutus

Dasometopus groenlandicus

Eodiscus scanicus

Olenoides cf. convexus

Opsidiscus longispinus

\section{Solenopleurella transversa?}

Fig. 3. Polymeroid trilobites in GGU collections from basal beds of the Kap Stanton Formation on the east side of Frankfield Bugt, Nyeboe Land (locality 2, Fig. 1). Collections are from the lower part of the Ptychagnostus atavus Interval-zone.

accompanying paper by Ineson et al. (1994), who also present a general description of the geologic environment. The Henson Gletscher Formation in southern Freuchen Land contains trilobites of Early to Middle Cambrian age (Blaker, 1986, 1991; see also Higgins et al., 1991), but all the collections described here are of Middle Cambrian age. Trilobites of only Middle Cambrian age have been previously reported from the Kap Stanton Formation (Fletcher et al., 1988; Babcock \& Robison, 1989; Robison \& Babcock, 1990).

Locality 1 (Figs 1, 2), at Hand Bugt, Nyeboe Land, includes a $90 \mathrm{~m}$ thick succession of the upper Henson Gletscher Formation and lower Kap Stanton Formation. Seven collections were obtained by J. S. Peel and M. R. Blaker in 1985 (Fig. 2).

Locality 2 (Figs 1,3) includes basal beds of the Kap Stanton Formation on the east side of Frankfield Bugt, Nyeboe Land. Two collections containing trilobites were made by A. K. Higgins in 1985 (Fig. 3). GGU 319789 was collected from talus, but GGU 319790 was collected in place. GGU 319789 is interpreted to be of local origin because separate slabs in the two collections contain parts and counterparts of the same trilobites (e.g., Olenoides $\mathrm{cf}$. convexus, Fig. 14.2).

Locality 3 (Figs 1,4) includes basal beds of the Kap Stanton Formation on a cape on the east side of J. P. Koch Fjord, north of the island of Primus, western Peary Land. Four collections were made at the locality, one by A. K. Higgins in 1984, and the others by J. S. Peel and M. R.
Blaker in 1985 (Fig. 4). The locality is approximately 40 $\mathrm{km}$ north of the type locality of the Holm Dal Formation (Fig. 1; see Peel, 1988).

\section{Depositional environments}

Similarities in major lithofacies and biofacies patterns indicate that Greenland and much of North America were united in a single continent, Laurentia, during Cambrian time (e.g., Palmer, 1974). Thick and widespread carbonate deposits support palaeomagnetic evidence that the continent was located in tropical latitudes (e.g., Scotese $e t$ al., 1979; Scotese, 1987; Scotese \& McKerrow, 1990; see Babcock, 1994, fig. 2).

The depositional settings of the Henson Gletscher Formation in Nyeboe Land and the Kap Stanton Formation in Nyeboe Land and Peary Land are described more fully and interpreted in an accompanying paper (Ineson et al., 1994). Both formations represent deposition in an openmarine, mainly low-energy environment below normal wave base. Sedimentation occurred seaward of an extensive carbonate platform that bordered the craton. In the northern outcrop belt, a carbonate-starved, outermost shelf-slope environment is inferred for most of the Henson Gletscher Formation, and a carbonate slope apron to carbonate-starved outermost shelf setting is inferred for the Kap Stanton Formation. Poor circulation may have resulted in oxygen-deficient bottom waters that inhibited sediment bioturbators. Thinly laminated carbonate and siliciclastic muds and silts accumulated mainly from suspension; thin beds of coarser sediment probably represent

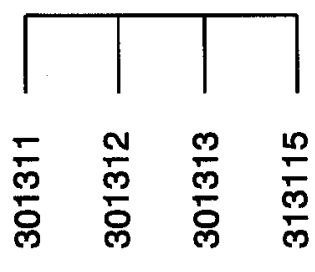

Anomocarina excavata

Centropleura angelini?

Centropleura loveni

Elyx trapezoidalis

\section{Solenopleura bucculenta}

Fig. 4. Polymeroid trilobites in GGU collections from basal beds of the Kap Stanton Formation on a cape on the east side of J. P. Koch Fjord, north of the island of Primus, Peary Land (locality 3, Fig. 1). Collections are all from the lower part of the Lejopyge laevigata Interval-zone. GGU 301312, 301313, and 313115 are from the same stratigraphic level, and GGU 301311 is from approximately three metres lower in the section. 


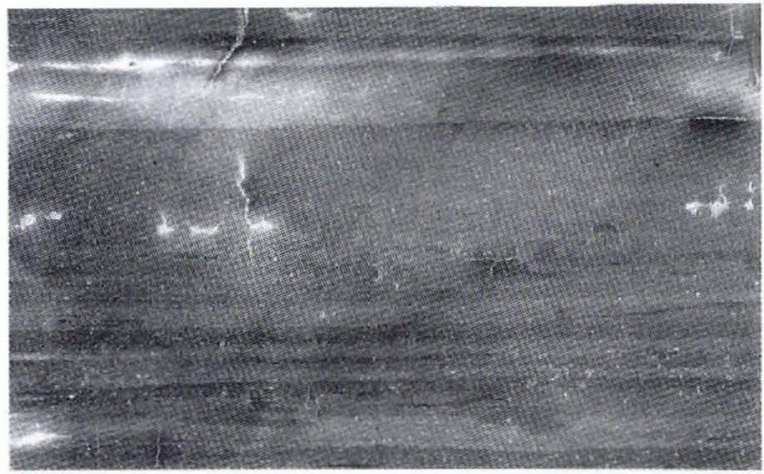

1

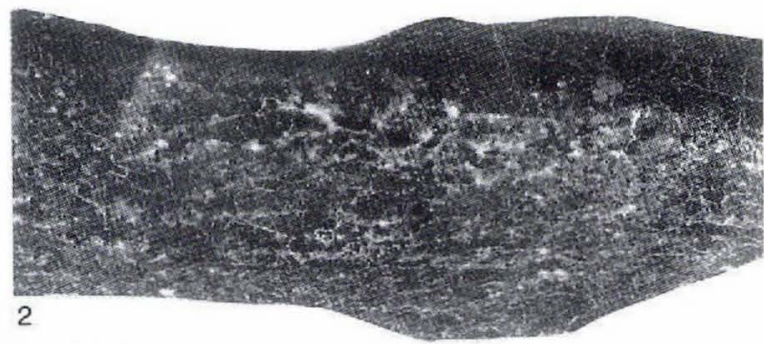

Fig. 5. Examples of major carbonate lithofacies from inferred deep-water environments, both $\times 1$; polished slabs are cut perpendicular to bedding; 1, mudstone (MGUH 21.229) from GGU 313115 , Lejopyge laevigata Zone; 2, packstone (MGUH 21.230) from GGU 319789, Ptychagnostus atavus Zone.

deposition from dilute turbidity currents or possibly storm-generated currents. Some intercalated grainstone or packstone beds represent episodic deposits resulting from tractional bottom currents.

Most trilobites in collections from the Ptychagnostus gibbus to Lejopyge laevigata zones are preserved in one of two carbonate lithofacies: packstone or mudstone (Fig. 5). Those from the Glossopleura zone, however, are in wackestone. More than 50 percent of the Henson Gletscher and Kap Stanton formations at locality 1 is dark grey to black limestone or dolostone. Most of the rock is lime mudstone with lesser amounts of argillaceous lime mudstone. Locally the mudstone grades to wackestone.

The mudstone facies (Fig. 5.1) is characterised by dark grey or black colour, thin bedding to millimetre-thick laminae, and lack of burrowing. Most bedding surfaces are planar and nearly parallel to slightly undulatory and discontinuous. The major constituent of the rock is finegrained carbonate. Minor constituents are spar, clay- and silt-sized siliciclastics, and pyrite. Most of the fauna consists of agnostoid trilobites, polymeroid trilobites of Baltic aspect, and sponge spicules. Inarticulate brachiopods are rare. In mudstone, the presence of some articulated exoskeletons or molt assemblages and lack of obvious size sorting or fragmentation of disarticulated sclerites suggests that most of the trilobites lived at or near where their remains were deposited.

Packstone beds (Fig. 5.2) are of centimetre-scale thickness and are intercalated with mudstone. Locally they grade to grainstone or wackestone. Their bases truncate the mudstone laminae over which they were deposited. Where evident, grading is crude and fines upward. The tops of beds form sharp contacts with overlying millimetre-thick laminae of mudstone. In packstone, nearly all trilobites are disarticulated and the sclerites are commonly fragmented, crudely size sorted, and mixed with shells of hyoliths, hyolithellids, helcionelloids, inarticulate brachiopods, and ostracodes. Remains of trilobites of both Laurentian and Baltic aspect are present, although those of Laurentian aspect are much more common. Together, the evidence suggests that fossils in packstone beds were transported downslope as bioclastic debris by gravity flow. The total species diversity in packstone was probably increased by redeposition of bioclasts. Also, trilobites of slightly different ages may have been mixed, although evidence of such mixing was not detected. Foreign sediment was not found adhering to specimens, nor were clasts discovered in the packstones. Judging from the biostratigraphic ranges of taxa in the packstones, there is no association of polymeroids that cannot be attributed to ecological differences between biofacies.

\section{Biostratigraphy}

Both polymeroid and agnostoid trilobites are present in Middle Cambrian rocks of North Greenland although they do not always co-occur. They have very different stratigraphic and geographic distributions, which accords with inferred basic differences in their modes of life (e.g., Robison, 1976). Agnostoids, most of which were probably pelagic (Robison, 1972; Öpik, 1979), are found mainly in lithofacies representing open-shelf and slope environments. Polymeroids, most of which were benthic, are most abundant in open-shelf or restricted-shelf lithofacies. Separate biozones based on agnostoids and polymeroids have been proposed for some major Middle Cambrian biofacies (Robison, 1976). Zonation of polymeroids is described below, and the more refined zonation of agnostoids is discussed in an accompanying paper (Robison, 1994). In the systematic descriptions of taxa in this paper, reference is made to one or both sets of zonation, as appropriate.

The age of GGU collections 298971-298973 from near the middle of the Henson Gletscher Formation of locality 1 (Fig. 2) is based on only polymeroid trilobites because agnostoids are not present. All identified genera are relatively eurytopic and long-ranging and are wide- 
spread primarily in open-shelf lithofacies of Laurentia. The presence of Glossopleura walcotti in all three collections indicates that they belong to the Glossopleura Assemblage-zone of Robison (1976).

Trilobites representative of three of the four agnostoid interval-zones defined by Robison (1984) were found at locality 1 . In ascending order these are the Ptychagnostus gibbus, Ptychagnostus atavus, and Lejopyge laevigata interval-zones. In North Greenland, taxa representing the Ptychagnostus punctuosus Zone were reported by Poulsen (1969; see also Robison, 1984, p. 35) from northern Nyeboe Land.

The Ptychagnostus gibbus Zone is represented by one collection, GGU 298970, from the Henson Gletscher Formation of locality 1 (Fig. 2). Although most polymeroids in the collection are long-ranging, the faunal association is consistent with a position close to the boundary between the Oryctocephalus and Bolaspidella assemblagezones of Robison (1976).

The Ptychagnostus atavus Zone is represented by five collections. Three of them, GGU 298969, 298974, and 298975, are from the upper Henson Gletscher Formation of locality 1 (Fig. 2). GGU 298969 contains a species of Syspacephalus that may represent an upward extension in the observed range of this genus. Two other collections,
GGU 319789 and 319790, are from basal beds of the Kap Stanton Formation of locality 2 (Fig. 3).

The Lejopyge laevigata Zone is represented by four collections, 301311 to 301313 and 313115 , from the basal beds of the Kap Stanton Formation of locality 3 (Fig. 4). Of the identified polymeroids from North Greenland, all four genera and four of five species are also present in the informal lower L. laevigata Interval-zone of Robison (1984; equivalent to the zone of Solenopleura brachymetopa of Westergård, 1953), indicating a close correspondence in age with the Andrarum Limestone of Sweden (see Berg-Madsen, 1985).

\section{Biogeography}

As elaborated more fully in an accompanying paper (Babcock, 1994), Middle Cambrian rocks of the Henson Gletscher and Kap Stanton formations in Nyeboe Land and Peary Land contain polymeroid trilobites (which are described in this paper) of Laurentian and Baltic aspect. Polymeroids from the Glossopleura and Ptychagnostus gibbus zones are mostly of Laurentian aspect. Those in the Ptychagnostus atavus Zone are of mixed Laurentian and Baltic aspect, and those in the Lejopyge laevigata Zone are entirely of Baltic aspect.

\section{Systematic descriptions}

\section{Terminology}

Most morphological terms used here are defined in the Treatise on Invertebrate Paleontology (Harrington et al., 1959a). Terms for lateral glabellar furrows and facial sutures are from Henningsmoen (1957, pp. 12-14). The term genal bar, applied to the family Paradoxididae, was defined by Öpik (1961). Morphological terms for genal caeca follow Jell (1978, pp. 251-253). The term eye ridge is used in a morphological sense even if part of the structure appears to belong to the caecal network. Terms for heterochronic processes follow McNamara (1986a, 1986b).

\section{Repositories}

All material referred to in this paper is identified by collection or museum numbers if known. Institutions and their acronyms are: Geological Survey of Greenland (Grønlands Geologiske Undersøgelse), Copenhagen (GGU); Geological Survey of Sweden, Uppsala (SGU);
Geologisk Museum, Copenhagen (MGUH); Swedish Museum of Natural History (Naturhistoriska Riksmuseet), Stockholm (RM); Sedgwick Museum, Cambridge (SM); and U.S. National Museum of Natural History (Smithsonian Institution), Washington, D.C. (USNM).

\section{Phylum Arthropoda \\ Class Trilobita \\ 'Polymerida'}

Remarks. The Polymerida has been treated by some authors as an order within the Trilobita. Based on phylogenetic analyses discussed under the 'Eodiscidae', the polymeroids are here interpreted to be a paraphyletic group defined as all trilobites exclusive of the highly derived Agnostida and the Nektaspida (see Fig. 27). The recent trilobite classification of Fortey (1990) cannot be applied at this time because of insufficient knowledge about ventral cephalic characters for many of the taxa discussed in 


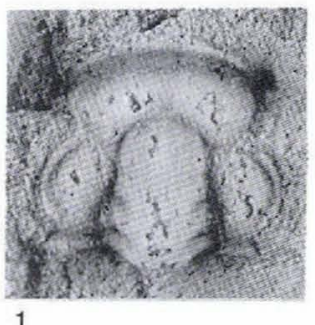

1

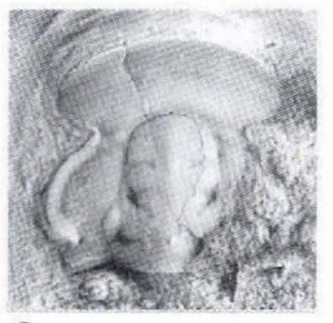

2

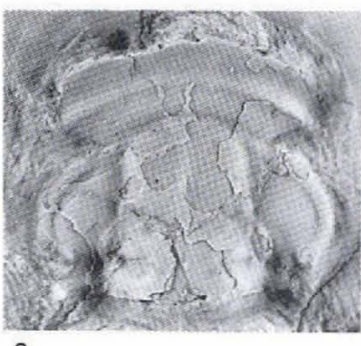

3

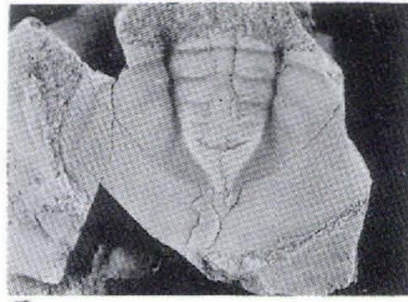

$\overrightarrow{4}$

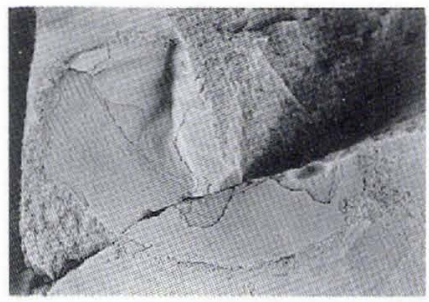

5

Fig. 6. Anomocarina excavata (Angelin). All specimens from GGU 301313.

1, small exfoliated cranidium, MGUH $21.231, \times 8.2$, incomplete testaceous cranidium, MGUH 21.232, $\times 4$. 3, incomplete, partly exfoliated cranidium, MGUH 21.233, × 2.5. 4, incomplete, partly exfoliated pygidium, MGUH $21.234, \times 2.5$, incomplete, partly exfoliated pygidium, MGUH 21.235, × 2 .

this paper. For convenience, therefore, the term polymeroid is used here, but only in an informal sense.

\section{Family Anomocaridae Poulsen Genus Anomocarina Lermontova, 1940}

Anomocarina Lermontova, 1940, p. 156; Westergård, 1950, pp. 14, 17; Howell in Harrington et al., 1959b, p. O287; Balashova et al. in Chernysheva, 1960, p. 92

Type species. Proetus? excavatus Angelin, 1851, p. 22.

Remarks. The generic concept of Westergård (1950, p. 14) is followed here.

\section{Anomocarina excavata (Angelin, 1851)}

Fig. 6

Proetus? excavatus Angelin, 1851, p. 22, pl. 18, fig. 3; Angelin, 1878 , p. 22 , pl. 18 , fig. 3

Anomocare excavatum (Angelin). Angelin, 1854, p. 25; Angelin, 1878 , p. 25, pl. 18, fig. 3; Brøgger (in part), 1878, pp. 39, 40, pl. 3, fig. 14a (not 14); Grönwall (in part), 1902, p. 140 (not pl. 4, fig. 6); Holm \& Westergård, 1930, pp. 16, 17, pl. 2, figs $1-14$, pl. 4, figs 19-21

Anomocarina excavatum (Angelin). Lermontova, 1940, p. 156, pl. 48 , figs 3 , 3a-m

Anomocarina excavata (Angelin). Westergård, 1950, pp. 17-19, pl. 3, figs 12-19; Kobayashi, 1962, pp. 107, 110, fig. 12b; Rosova, 1964, pp. 31, 32, pl. 1, figs 7-15, pl. 3, figs 21-23; Howell in Harrington et al., 1959b, p. O287, fig. 212,4; Reyment, 1980, p. 8, figs 17a, 17b (copy of Angelin, 1878, pl. 18, fig. 3)

Anomocarina cf. excavata (Angelin). Westergård, 1950, p. 19. pl. 3 , fig. 20
Lectotype. Pygidium, RM Ar. 1433.

New material. Two small- to medium-sized holaspid cranidia, two possible meraspid cranidia, and three holaspid pygidia; all in GGU 301313.

Remarks. The holaspides of A. excavata agree in all characters with specimens of similar size previously described or figured from Scandinavia (Westergård, 1950), Siberia (Lermontova, 1940), and Bennett Island (Holm \& Westergård, 1930). Possible meraspid cranidia differ from larger specimens primarily in having somewhat narrower anterior areas of the fixigenae, a slightly longer preglabellar field, and slightly longer palpebral lobes.

Occurrence. Sclerites of A. excavata are present in dark mudstone of the basal beds of the Kap Stanton Formation at locality 3, Peary Land. Elsewhere, this species has been reported from Sweden, Norway, Denmark, Siberia, and Bennett Island. It has been reported from only the Lejopyge laevigata Interval-zone.

\section{Family Conocoryphidae Angelin Genus Dasometopus Resser, 1936}

Dasometopus Resser, 1936, p. 22; Westergård, 1950, pp. 34, 35; Chernysheva, 1953, p. 16; Poulsen in Harrington et al., 1959b, pp. O242, O243; Suvorova in Chernysheva, 1960, p. 117

Type species. Harpides breviceps Angelin, 1854, p. 87, by original designation (Resser, 1936, p. 22). 
Emended diagnosis. Cephalon semicircular, much wider than long; anterior margin broadly rounded, rarely straight medially; border narrow, may be thickened. Glabella subconical, approximately half cranidial length. widest at base, tapering forward; with three distinct pairs of lateral furrows. Preglabellar field having longitudinal depression. Gena moderately convex, covered with inosculating type 4 caeca. Facial suture absent. Caecal ridge of type 3, distinct. Eyes absent. Thorax with about 24 segments; axis narrow; pleura more than twice as wide as axis, flattened, with distinct interpleural furrow, terminating in long, narrow, backwardly directed spine, marginal spine on twelfth segment greatly elongated, width of pleural lobe decreasing backward from twelfth segment. Pygidium micropygous, subtriangular, having short, narrow marginal spines.

Remarks. Representatives of Dasometopus are presently known from Sweden, Denmark, Siberia, and North Greenland. Described species include D. breviceps (Angelin, 1854), D. latus Korobov, 1973, D. granulatus Korobov, 1973, D. maensis Korobov, 1973, D. munacaensis Korobov, 1973, D. rectus Korobov, 1973, and D. groenlandicus $\mathrm{n}$. sp. Another species, D.? incerius Westergård, 1950 , from Sweden, may represent an undescribed genus. It is discussed further in remarks on Elyx.

Specimens of Dasometopus from Sweden are in the Ptychagnostus punctuosus and Lejopyge laevigata interval-zones. Those from Siberia range from the Paradoxides hicksii - Tomagnostus fissus Zone through the Anomocarioides limbataeformis Zone of Korobov (1973), which probably corresponds to a range from the Ptychagnostus atavus through Lejopyge laevigata zones of Robison (1984). New specimens from North Greenland are in the $P$. atavus Zone.

Dasometopus groenlandicus n. sp. Fig. 7

Etymology. From Grønland (Greenland).

Holotype. Cephalon, MGUH 21.236.

Material. One small complete cephalon and numerous fragments of larger cephala in GGU 319789 and 319790.

Diagnosis. Dasometopus having posterior cephalic margin slightly bowed forward over most of its length; border thickened anteriorly and laterally; border furrow moderately wide medially, narrowing slightly at sides; glabella tapering very slightly toward anterior, bluntly rounded anteriorly; large baccula present in axial furrow; eye ridge strong, arcuate, extending nearly to border; surface covered with widely spaced granules except on axis and border.

Description. Cephalon nearly twice as wide as long, evenly rounded through anterior and lateral margin, posterior margin slightly bowed forward over most of length; border narrow, thickened anteriorly and laterally, upturned posteriorly; border furrow shallow, moderately wide medially, narrowing slightly laterally; posterior border furrow deep, moderately wide. Glabella convex, raised above gena; slightly less than one-half cranidial length; widest at L1, slightly tapering forward; bluntly rounded anteriorly; lateral furrows distinct, deep at back,
Fig. 7. Dasometopus groenlandicus n. $\mathrm{sp}$. All specimens from GGU 319790.

1, holotype cephalon (a) and latex cast of counterpart (b), MGUH 21.236, × 10. 2, incomplete cephalon, MGUH 21.237, x 2.5. 3, incomplete cephalon, MGUH 21.238, $\times 2.5$. 4. incomplete cephalon, MGUH $21.239, \times 2.5$.

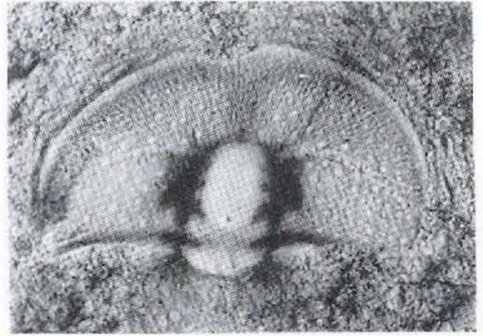

$1 \mathrm{a}$

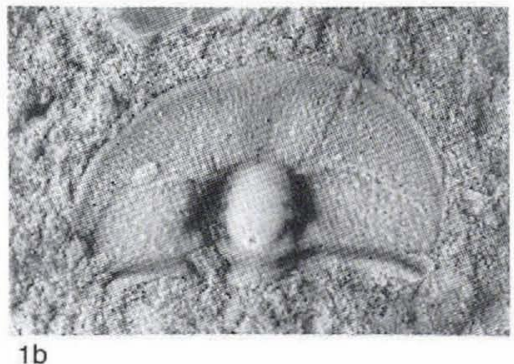

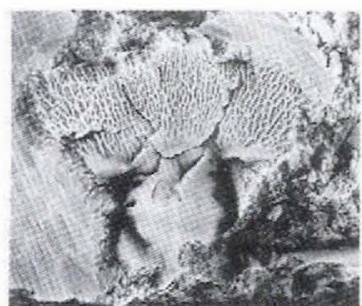

2

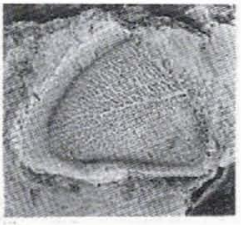

3

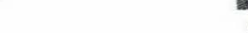

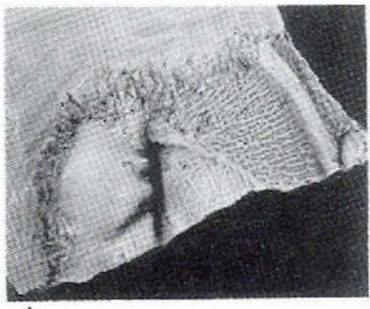

4 
slightly shallowing forward; S1 bifurcate, oblique backwards; S2 and S3 transverse. Occipital ring convex, without node or spine; occipital furrow moderately wide and shallow medially, deep and narrow at side. Gena moderately convex, comprising large raised area behind caecal ridge and smaller raised area in front of caecal ridge, separated by wide, shallow depression; covered with inosculating caeca, some connecting with caecal ridge; raised lines stronger in front of caecal ridge. Preglabellar field wide, subequal in length with glabella; preglabellar depression wide, shallow. Axial furrow distinct, wide posteriorly, narrowing anteriorly; baccula present in posterior one-quarter. Caecal ridge strong, arcuate; beginning in axial furrow at middle of L4, extending nearly to border. Facial suture and eye absent. Surface of genae covered with strong, widely spaced granules.

Thorax and pygidium unknown.

Remarks. Cephala of D. groenlandicus n. sp. differ from those of all other species in the genus by the combination of a posterior border that is slightly bowed anteriorly over most of its length, a glabella that slightly tapers forward and is bluntly rounded anteriorly, the presence of bacculae in the axial furrows, and the presence of widely spaced granules on the genae.

The holotype cephalon of $D$. groenlandicus is small for the species and is probably a young holaspid. Although it is only one-sixth the maximum observed cranidial length, it does not seem to differ significantly in proportion or surface markings from larger specimens.

Occurrence. Broken cephala are relatively common in dark mudstone beds of the basal Kap Stanton Formation at locality 2, Nyeboe Land. They are associated with trilobites indicative of the Ptychagnostus atavus Intervalzone.

\section{Genus Elyx Angelin, 1851}

Eryx Angelin, 1851, p. 4 [corrected to Elyx, 1854, p. X]; Lindström, 1901, p. 10

Elyx Angelin, 1854, p. X; Angelin, 1878, p. 4 [incorrectly cited as Eryx; corrected p. X]; Howell, 1937, p. 1169; Westergård, 1950, p. 32; Poulsen in Harrington et al., 1959b, pp. O243, O244; Lermontova in Chernysheva, 1960, p. 118; Hutchinson, 1962 , p. 98

Type species. Eryx laticeps Angelin, 1851, p. 4, by monotypy.

Emended diagnosis. Cephalon truncated anteriorly, much wider than long; anterior margin very slightly rounded, straight, or concave medially; anterolateral margin angu- lar to very narrowly rounded; posterolateral margin rounded; border narrow, convex, upturned anteriorly; border furrow deep; preglabellar boss joins anterior border. Glabella subconical, convex, widest at base, moderately tapering forward, truncated anteriorly, with 3 pairs of lateral furrows. Gena convex. Facial suture and eyes absent.

Thorax with 11 to 13 segments. Axis narrow, convex. Pleurae wide, flattened, tips falcate; pleural furrows shallow, wide.

Pygidium small.

Remarks. Eryx was erected by Angelin $(1851$, p. 4) but, in a corrigendum published in the second fasciculus of the same work (1854, p. X), the name was emended to Elyx. The change in spelling is demonstrably intentional (see International Code of Zoological Nomenclature, Art. 33 (b) (i); International Commission on Zoological Nomenclature, 1985), and the spelling Elyx has been subsequently adopted by all authors except Lindström (1901). Westergård $(1950$, p. 32) stated that the name of this trilobite was emended because Eryx was preoccupied, but Angelin did not state a reason for the emendation. The date of publication of Elyx is 1851, the year in which the misspelled name was first used.

Nine described species, all of middle to late Middle Cambrian age, are here included in Elyx: E. laticeps (Angelin, 1851) from Sweden, Denmark, Norway, and Siberia; E. matthewi Hutchinson, 1962, from south-eastern Newfoundland; E. trapezoidalis n. sp. from North Greenland; and E. alatus Korobov, 1973, E. arcus Korobov, 1973, E. graevis Korobov, 1973, E. nelegerensis Korobov, 1973, E. olenekensis Korobov, 1973, and E. palmeri Korobov, 1973, all from Siberia. Another species, E. americanus Howell, 1932, from St. Albans, Vermont, was transferred to Ctenocephalus (Resser, 1936, p. 20). E. latilimbatus Brøgger, 1878 , is known from a single cephalon that was only illustrated by a drawing (Brøgger, 1878, pl. 3, fig. 10). The specimen is probably an external mould of a conocoryphid trilobite but not Elyx. Although the anterior margin is concave medially, the figure shows no evidence of angular or narrowly rounded anterolateral corners or a preglabellar boss. The slightly tapering glabellar sides, wide anterior border, and wide lateral border are also different from those of Elyx.

Two conocoryphid species assigned by Korobov (1973) to Elyx, E. shatskii Korobov, 1973, and Dasometopus? incertus Westergård, 1950, are of questionable affinity and possibly represent an undescribed genus. $D$. ? incertus was based on a single fragmentary cephalon from the Andrarum Limestone of Scania, Sweden. $E$. shatskii was illustrated by two cephala from the Anomocarioides limbataeformis Zone of Siberia (Korobov, 
1973). Some important cephalic characters that distinguish these two species from Elyx are a semicircular outline without angular or narrowly rounded anterolateral corners, a glabella that is approximately half the length of the cranidium, and the presence of a narrow medial ridge in the preglabellar field rather than a subcircular boss. They differ from Dasometopus primarily in having a medial preglabellar ridge rather than a furrow, and a distinct border furrow.

Some authors (Grönwall, 1902; Strand, 1929; Resser. 1936, 1937a) have regarded Elyx to be a junior synonym of Ctenocephalus Corda, 1847, but I agree with Howell (1937), Westergård (1950), Poulsen in Harrington et al. (1959b), and Hutchinson (1962) in recognising that characters of the cephalon are sufficient to distinguish the two genera. In addition to differential characters listed by Westergård (1950, p. 32), Elyx differs from Ctenocephalus in the apparent lack of facial sutures. Westergård (1950, p. 32) stated that facial sutures, if developed, are marginal, but a specimen of Elyx showing sutures has not been reported. Specimens of E. trapezoidalis n. sp. from North Greenland, which are preserved in relief, show that facial sutures are not present dorsally, marginally, or ventrally.

One species, E. matthewi, was described (Hutchinson, 1962 , p. 99) as having well-rounded anterolateral corners, not angular, as are usual for the genus. Of the four specimens identified by Hutchinson (1962, pl. 13, figs 3-6) as E. matthewi, however, none shows an intact anterolateral margin. A small cephalon of a conocoryphid trilobite that was figured by Hutchinson (1962, pl. 12, fig. 16) as Ctenocephalus (Hartella) terranovicus Resser, 1925, agrees in all characters with Elyx and differs from Ctenocephalus. That specimen, which probably belongs to E. matthewi, has a nearly complete, and evidently angular, anterolateral corner.

Specimens of Elyx from Sweden and Norway are in the Lejopyge laevigata Interval-zone. Those from Siberia range from the Corynexochus perforatus - Anopolenus henrici Zone through the Anomocarioides limbataeformis Zone of Korobov (1973), which probably corresponds to a range from the Ptychagnostus atavus through Lejopyge laevigata zones of Robison (1984). New specimens from North Greenland are in rocks of the L. laevigata Zone.

\section{Elyx trapezoidalis n. $\mathrm{sp}$. \\ Fig. 8}

Etymology. From Latin, trapezoides, referring to the trapezoidal outline of the cephalon.

Holotype. Cephalon, MGUH 21.240.
Material. Eight cephala or fragmentary cephala in GGU 301313.

Diagnosis. Elyx having comparatively short cephalon with subtly angular anterolateral corner, lateral border almost straight, genal angle broadly rounded, gena most convex on line with preglabellar furrow.

Description. Cephalon trapezoidal, short (sag.) for genus, anterior border slightly concave medially, anterolateral corners subtly angular, lateral border nearly straight and slightly converging forward, posterolateral corners broadly rounded. Axial furrows deep. Glabella elevated well above gena; S1 and S2 short, deep at side, oblique backward; S3 reduced to shallow pit. Occipital furrow deep at side, shallow medially. Occipital ring broken on all specimens, may have node or spine. Preglabellar field consisting of strong, well-defined boss. Gena convex, highest on line with preglabellar furrow, steeply sloping at margin to anterior and lateral section of border furrow and slightly sloping backward to posterior section of border furrow. Caecal ridge of type 3, weak, short, beginning forward of S1 and directed obliquely backward then laterally. Facial suture lacking. Surface of test covered with fine, closely spaced granules and larger, irregularly spaced granules, except in furrows; larger granules also present on internal mould.
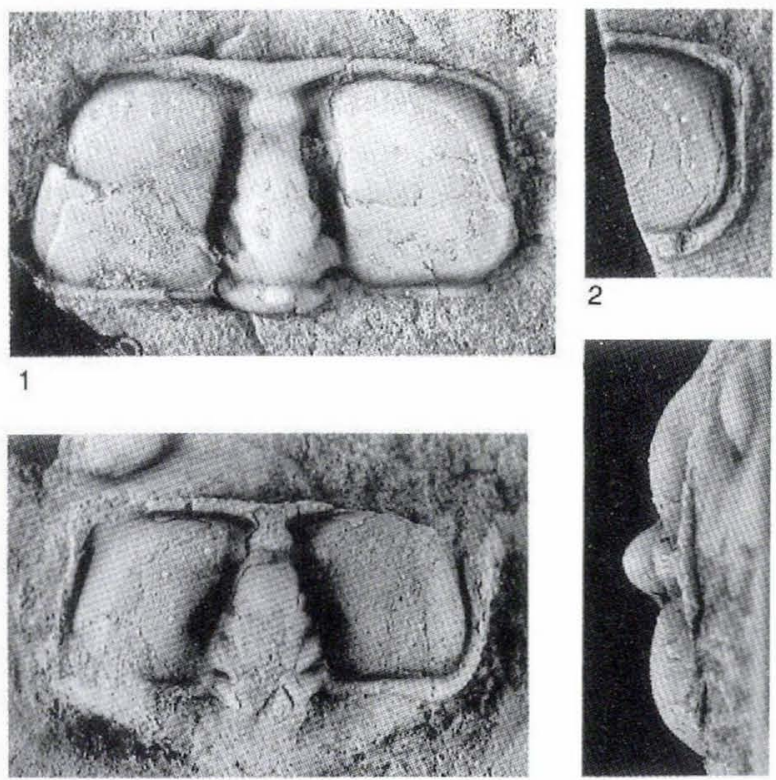

$3 a$

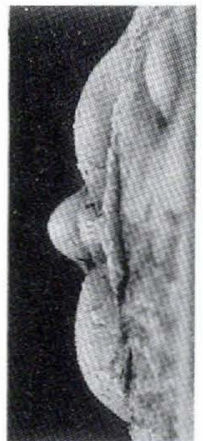

$3 b$

Fig. 8. Elyx trapezoidalis n. sp. All specimens from GGU 301313.

1, latex cast of holotype cephalon, MGUH 21.240, × 2. 2, right side of small cephalon MGUH 21.241, × 6. 3, mostly exfoliated cephalon in dorsal (a) and frontal (b) views, MGUH 21.242, ×4. 
Thorax and pygidium unknown.

Remarks. The cephalon of Elyx trapezoidalis n. sp. differs in outline and minor surface characters from that of other species of the genus. In having a comparatively short cephalon, which is concave along its anteromedial margin, E. trapezoidalis most closely resembles $E$. laticeps (Angelin, 1851) and E. matthewi Hutchinson, 1962. The anterolateral corners of E. trapezoidalis, however, are less angular than those of $E$. laticeps. At the anterolateral corner, the anterior border is lower than the lateral border of E. matthewi but not of E. laticeps. E. trapezoidalis has less well defined caecal ridges and S3 furrows than either $E$. laticeps or $E$. matthewi. Finally, the lateral margins of $E$. trapezoidalis are straighter than those of either $E$. laticeps or E. matthewi.

Occurrence. E. trapezoidalis is present in dark lime mudstone beds of the basal Kap Stanton Formation at locality 3, Peary Land.

\section{Genus Hartshillia Illing, 1916}

Hartshillia Illing, 1916, p. 424; Lake, 1938, pp. 262, 263, 268; Vodges, 1925, p. 101; Poulsen in Harrington et al., 1959b, p. O244; Hutchinson, 1962, p. 109

Type species. Holocephalina inflata Hicks, 1872, p. 178, by subsequent designation (Vogdes, 1925, p. 101).

Emended diagnosis. Cephalon semicircular, strongly convex, lacking border; external furrows mostly to completely effaced, but axial and S1 furrows well-defined on internal surface, other lateral glabellar furrows rarely expressed on internal surface. Glabella long, narrowest posteriorly, expanding forward; maximum width 0.3 to 0.5 times maximum cephalic width. Occipital ring with strong medial spine. Frontal area short. Fixigena strongly convex. Genal angle rounded, angular, or with genal spine. Facial suture probably absent. Eyes absent. Posterior border furrow weak, margin concave.

Labrum ovoid, central body convex, anterior wings large, border moderately wide.

Thorax with at least 8 segments. Axis slightly narrower than pleural lobe, convex. Pleural lobe nearly flat. Pleural groove straight for most of length, turned backward near pleural tips. Pleural tips short, falcate.

Pygidium small. Axis about as wide as pleural lobe, with 2 to 5 rings. Border wide, downwardly sloping.

Remarks. Hartshillia presently includes five species: $H$. inflata (Hicks, 1872), H. terranovica Hutchinson, 1962, H. clivosa Lazarenko, 1965, H. pusilla Lazarenko, 1965 , and H. taimyrica Lazarenko, 1965. Two species originally assigned to Hartshillia have been transferred to other genera. $H$. spinata Illing, 1916, was reassigned as the type species of the conocoryphid Hartshillina Lake (1940, p. 300), and H. marocana Gigout, 1951, was reassigned as the type species of the ellipsocephalid $\mathrm{Me}$ setaia Hupé (1953, p. 158). Illustrated specimens from Morocco (Termier \& Termier, 1950, pl. 191, figs 22-27) were misidentified as Hartschillia [sic] sp. Although the line drawings are poor, they are adequate to show that the specimens are not effaced, and have facial sutures and eyes. Although identification of the Moroccan specimens is uncertain, they resemble a generalised ptychopariid.

Marginal facial sutures have been reported in only $H$. inflata, the type species, but their presence is questionable. Illing (1916, p. 424) stated that "most of the specimens have no free cheeks, but some forms show a narrow border broken away from the head which appears to correspond to the free cheek, and it would appear probable that the facial suture was almost marginal and continuous in front." Later, Lake (1938, p. 268) reported that no facial sutures are shown on the upper surface, and Poulsen (in Harrington et al., 1959b, p. O244) reported that facial sutures were "apparently marginal." Facial sutures, if present in this species, are not convincingly illustrated in any of Illing's figures, nor are they present in any of the well-preserved specimens of $H$. inflata from North Greenland. Illing's figured specimens are preserved in shale and are crushed. They are predominantly internal moulds, but the margins of the now-missing test are defined by external moulds. Illing may have been misled by some artifact of preservation, and his material should be re-examined for the presence of facial sutures.

Where present in well-dated rocks, Hartshillia appears to be restricted to the middle and upper Middle Cambrian. Hartshillia inflata has been identified from St. Davids, Wales, and near Nuneaton, England, where it occurs with trilobites indicative of the Ptychagnostus atavus and $P$. punctuosus interval-zones. Specimens apparently belonging to $H$. inflata are associated with fossils of the $P$. atavus Zone in North Greenland. In southeastern Newfoundland, $H$. terranovicus is associated with trilobites indicative of the $P$. atavus Zone. Specimens described from Siberia (Lazarenko, 1965) are from the Paradoxides hicksii - Tomagnostus fissus and Corynexochus perforatus - Anopolenus henrici zones of Korobov (1973), and probably correspond in age to the Ptychagnostus gibbus through $P$. atavus zones of Robison (1984). 
Fig. 9. Hartshillia inflata (Hicks). All specimens from GGU 298969. 1 , cephalon in dorsal (a), frontal (b), and left-lateral (c) views, MGUH 21.243, × 5.2, incomplete cranidium in dorsal (a) and rightlateral (b) views, MGUH 21.244, $\times 5$. The right genal spine was broken and healed during life. Cephalon of Eodiscus scanicus (Linnarsson) to lower right of photograph (MGUH 21.245). 3, partly exfoliated cephalon, MGUH $21.246, \times 6$.
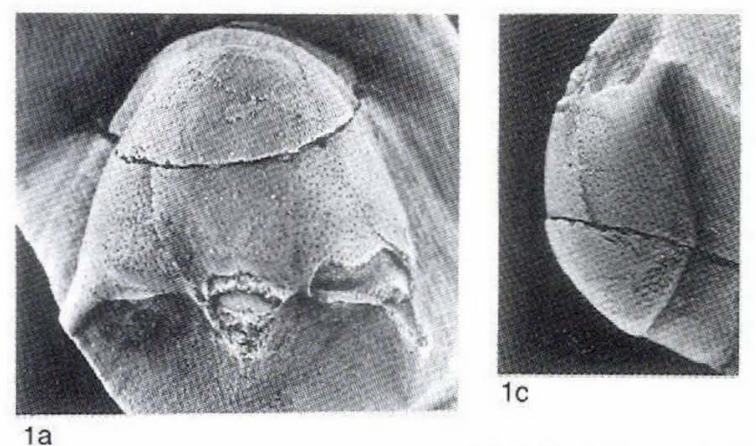

1c

$1 a$

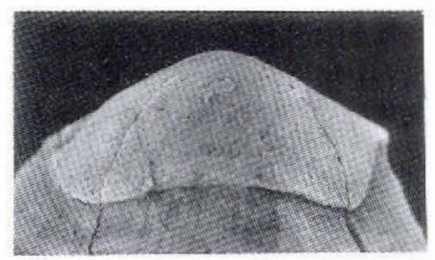

$1 \mathrm{~b}$

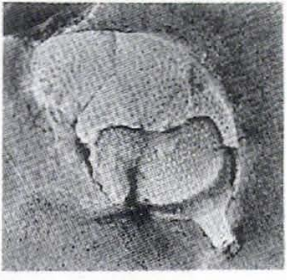

3

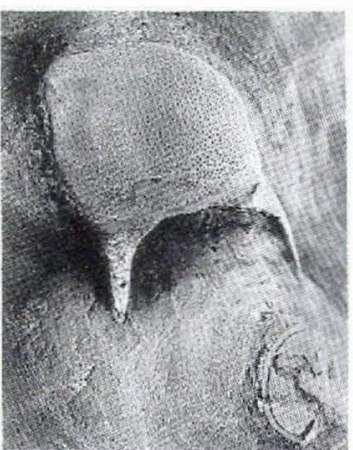

$2 a$

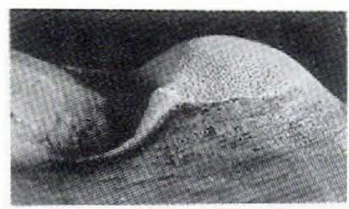

$2 b$
Hartshillia inflata (Hicks, 1872)

Fig. 9

Holocephalina inflata Hicks, 1872, p. 178, pl. 6, figs 8-10: Reed, 1898 , p. 497; Grönwall, 1902, p. 87

Hartshillia inflata (Hicks). Illing, 1916, pp. 424, 425, pl. 34, figs 1-5; Vogdes, 1925, p. 101; Lake, 1938, p. 268, pl. 38, figs 6-15; Lake, 1940, p. 300; Poulsen in Harrington et al., 1959b, p. O244, fig. 181,9; Morris, 1988, p. 106

Lectotype. Incomplete thorax and attached pygidium, SM A469, selected by Morris (1988, p. 106).

New material. Four cephala in GGU 298969.

Remarks. Hartshillia is represented by four cephala that seem to fall within the range of variation of specimens of $H$. inflata illustrated by Hicks (1872), Illing (1916), and Lake (1938) from England.

The new cephala range from semicircular to anteriorly elongate in outline, and have a width approximately 1.5 times the length. The single uncrushed specimen (Fig. 9.1 ) is very convex and has a strongly arched anterior border. Some of the variation in outline and convexity among specimens in the sample is evidently due to crushing. In the most extreme example (Fig. 9.3), evidence of the anterior arch is absent. All specimens are completely effaced, and covered with fine, densely spaced puncta. Furrows are not expressed on the outer surface but their positions are indicated by narrow linear bands lacking puncta. The position of the axial furrow is only indicated posteriorly. The genal spines are moderately long, narrow, straight, and impunctate. They extend backward from the posterior margin and, in profile view, are approximately three-fifths of the way up from the ventral edge of the cephalon. The occipital spine is short and strong. Facial sutures are absent.

Two partially exfoliated specimens reveal furrows and fine, closely spaced granules on the internal mould. The axial furrow is well defined posteriorly, and diverging and shallowing anteriorly. Both the occipital furrow and the posterior border furrow are well defined. The exoskeleton is thick over the effaced furrows and moderately thick elsewhere.

One specimen (Fig. 9.2) has a broken and healed right genal spine. The means by which breakage occurred is considered to be uncertain (see Babcock, 1993). The spine was broken near its base as indicated by an irregularly swollen knob. Where regrown, the spine is not straight as is usual, but is strongly curved downward and backward. In life, it evidently projected below the lower edge of the cranidium, suggesting that this species was pelagic, rather than benthic.

Previously, the cranidium of $H$. inflata has been described as having a punctate (Hicks, 1872, p. 178) or finely granulate (Illing, 1916, p. 424; Lake, 1938, p. 269) surface. The new material indicates that the external surface of the test is punctate and the internal mould is granulate.

Termier \& Termier (1950, p. 29, pl. 185, fig. 25) reported $H$. inflata from Morocco, but the cranidium upon which their determination was made was misidentified. The specimen, illustrated by only a line drawing, is twice as wide as long exclusive of the occipital spine, has facial sutures, and appears to be completely effaced ex- 


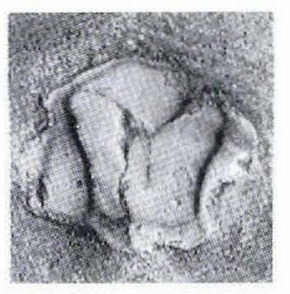

Fig. 10. Corynexochus? sp.; broken and crushed cranidium, MGUH 21.247 from GGU 319790, × 10 .

cept for the anterior and posterior border furrows. The specimen cannot be identified to genus from the original illustration, but the great relative width, the presence of facial sutures, and the presence of an anterior border furrow demonstrate that it is not Hartshillia.

Occurrence. H. inflata is present in wackestone $71 \mathrm{~m}$ above the base of the Henson Gletscher Formation at locality 1, Nyeboe Land. It is associated with trilobites of the Ptychagnostus atavus Zone. The species has been previously reported from various localities in the English Midlands (Hicks, 1872; Illing, 1916; Lake, 1938), where it occurs with trilobites indicative of the Ptychagnostus atavus and $P$. punctuosus interval-zones.

\section{Family Corynexochidae Angelin Genus Corynexochus}

\section{Corynexochus? sp.}

Fig. 10

Remarks. A species of corynexochid, probably Corynexochus, is represented by a single, small, fragmentary, crushed cranidium in GGU 319790. The cranidium is characterised by a glabella that reaches to the anterior border and that is strongly expanded anteriorly. Three weak lateral glabellar furrows are present; $\mathrm{S} 1$ is directed obliquely backward; S2 and S3 seem to be shallow depressions at the axial furrow. The anterior area of the fixigena is narrow, and approximately one-third as wide as the posterior area. The palpebral lobes are moderately long.

Occurrence. Present in the basal beds of the Kap Stanton Formation at locality 2, Nyeboe Land. It occurs with trilobites indicative of the Ptychagnostus atavus Intervalzone.

\section{Family Dolichometopidae Walcott Genus Bathyuriscus Meek, 1873}

Bathyuriscus Meek, 1873, p. 484; Walcott, 1886, p. 215; Walcott, 1916, pp. 330-334; Resser, 1935, p. 13; Kobayashi, 1942a, p. 155; Kobayashi, 1942b, p. 471; Lake, 1934, p. 186;

Shimer \& Shrock, 1944, p. 607; Poulsen in Harrington et al., 1959b, p. O224; Robison, 1964, p. 534; Palmer, 1968, p. B44; Robison, 1976, p. 102; Young \& Ludvigsen, 1989, pp. 14, 15 Orria Walcott, 1916, p. 379; Kobayashi, 1942a, p. 172; Kobayashi, 1942b, p. 473; Shimer \& Shrock, 1944, p. 613; Poulsen in Harrington et al., 1959b, p. O224

Oriella Rasetti, 1948b, p. 329; Poulsen in Harrington et al., 1959b, p. O225

Wenkchemnia Rasetti, 1951, pp. 183, 184; Poulsen in Harrington et al., 1959b, p. O226; Suvorova \& Chernysheva in Chernysheva, 1960 , p. 76

Type species, Bathyurus(?) haydeni Meek, 1873, p. 484, by original designation (Meek, 1873, p. 484).

Remarks. The generic diagnosis of Robison (1964, pp. 534,535 ) is followed here. It is modified, however, to cite only one pair of fossulae, rather than two pairs, in the axial furrow. Based on examination of a large number of specimens in the U.S. National Museum and at the University of Kansas, I agree with the conclusion that Wenkchemnia is a junior synonym of Bathyuriscus (Robison, 1976, p. 102), although detailed evidence supporting that conclusion has yet to be published.

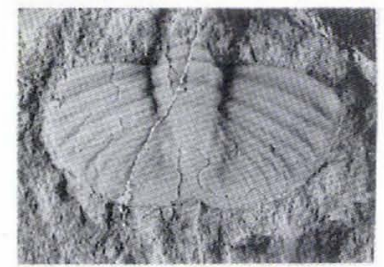

$1 \mathrm{a}$

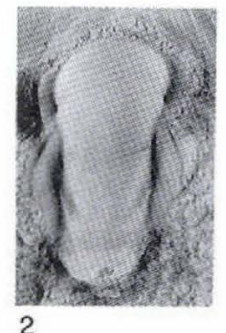

2

Fig. 11. Specimens of Bathyuriscus.

1-2, Bathyuriscus concavus n. sp., both from GGU 319790. 1, holotype pygidium (a) and latex cast of counterpart (b), MGUH 21.248, × 3. 2, incomplete cranidium, MGUH 21.249, $\times 2$.

3-4, Bathyuriscus sp., both from GGU 298970. 3, incomplete pygidium, MGUH 21.250, × 5. 4, incomplete cranidium, MGUH 21.251, × 2 . 
Bathyuriscus concavus n. sp.

Fig. 11.1, 2

Etymology. From Latin, concavus, hollowed or arched inward, referring to the posteromedial notch in the pygidium.

Holotype. Pygidium, MGUH 21.248.

Material. One cranidium and two pygidia in GGU 319790.

Diagnosis. Cranidium having fixigena with narrow anterior area. Lateral glabellar furrows weak; axial furrow moderately shallow; fossula moderately deep. Pygidium with distinct posteromedial notch; axis with four rings and long terminal piece; pleural lobe with six pleural furrows and five interpleural furrows.

Description. Cranidium known from only one broken specimen. Glabella moderately convex, long, slender posteriorly, expanding evenly forward, extending nearly to anterior margin; lateral furrows weak. Axial furrow moderately shallow, fossula moderately deep. Occipital ring broken medially, but evidently with node or spine. Fixigena wide anteriorly, relatively narrow just behind palpebral lobe, posterior area not preserved. Palpebral lobe gently curved, moderately well-defined by weak palpebral furrow; length about one-half of glabellar length; anterior end of palpebral furrow intersects axial furrow just behind fossula. Posterior border not preserved. Librigena unknown. Surface smooth.

Thorax unknown.

Pygidium transverse, width about twice length, having distinct posteromedial notch, anterolateral spine absent. Axis low, moderately tapering, anterior width more than one-quarter width of pygidium; having 4 rings, long terminal piece, and postaxial ridge extending almost to posterior border. Axial furrows shallowing posteriorly. Pleural field low, with 6 moderately wide pleural furrows and 5 narrower interpleural furrows. Surface smooth.

Remarks. B. concavus differs from all other species of the genus in having a moderately short and wide pygidium with four rings and a long terminal piece in the axis, six pleural furrows, and a distinct posteromedial notch.

Two species from Utah, B. brighamensis Resser, 1939a, and B. wasatchensis (Resser, 1939b), also have distinct posteromedial notches in the pygidium. The pygidium of $B$. concavus is slightly narrower and less triangular in outline than that of $B$. brighamensis. It also differs in the lack of small anterolateral spines, which are present in some specimens of $B$. brighamensis. B. conca- vus differs from $B$. wasatchensis in having a more transverse outline, and lacking well-developed anterolateral spines.

Occurrence. Rare in packstone of the basal beds of the Kap Stanton Formation at locality 2, Nyeboe Land. It is associated with trilobites indicative of the Ptychagnostus atavus Interval-zone of Robison (1984).

\section{Bathyuriscus sp.}

Fig. 11.3, 4

Material. Two cranidia and two pygidia in GGU 298970.

Remarks. Four sclerites belonging to this unassigned species are in GGU 298970. They are from small holaspides and are too poorly preserved for meaningful comparison with other species.

The available cranidia are fragmentary. The glabella is moderately long for the genus and wide anteriorly. Only the S1 and S2 furrows are distinct, the S1 furrows being moderately deep. The fossulae are moderately deep. The anterior area of the fixigena is narrow. The palpebral lobes are incomplete.

The available pygidia are small and broken. They appear to have been relatively transverse, and without a distinct posteromedial notch. The axis is relatively convex, moderately tapering, and contains five rings, a terminal piece, and a postaxial ridge. The pleural field is low, and has five wide pleural furrows and four narrower interpleural furrows. The surface is smooth.

Occurrence. Rare in a packstone bed from approximately $56 \mathrm{~m}$ above the base of the Henson Gletscher Formation at locality 1. It is associated with trilobites indicative of the Ptychagnostus gibbus Interval-zone of Robison (1984).

\section{Genus Glossopleura Poulsen, 1927}

Glossopleura Poulsen, 1927, p. 268; Kobayashi, 1935, p. 132; Shimer \& Shrock, 1944, p. 611; Rasetti, 1951, p. 163; Palmer, 1954, p. 67; Rusconi, 1954; Poulsen in Harrington, 1959b, p. O224; Suvorova \& Pokrovskaia in Chernysheva, 1960, p. 76; Poulsen, 1964, p. 25

Bathyuriscus (Glossopleura) Poulsen. Kobayashi, 1942a, pp. 159, 160; Kobayashi, 1942b, p. 471 [misspelled Glossopheura]

Sonoraspis Stoyanow in Cooper et al., 1952, pp. 50-53

Type species. Dolichometopus boccar Walcott, 1916, p. 363; by original designation (Poulsen, 1927, p. 268).

Remarks. The generic concept of Palmer $(1954$, p. 67) is 
followed here. His diagnosis is emended, however, to include species having a short anterior border in front of the glabella, a small node on the occipital ring, or medial nodes or spines on the axial lobe of some thoracic segments.

More than 50 species of Glossopleura have been described from western North America, North Greenland, and the Precordillera terrane of Argentina. Many species are in need of re-evaluation, but discriminating among some species can be difficult because furrows on the dorsal surface are generally weakly expressed in holaspides and because exoskeletal convexity, which has been used as a character for diagnosing species, can be influenced by compaction. The pygidial outline and width of the pygidial border can vary within rather wide limits in a species, as shown by specimens of $G$. walcotti (Fig. 12.3-12.6).

\section{Glossopleura walcotti Poulsen, 1927}

Figs 12; 13.6

Glossopleura walcotti Poulsen, 1927, pp. 268, 269, pl. 16, figs 20-30; Poulsen, 1946, p. 318; Poulsen, 1964, pp. 25-29, pl. 1 , figs 2-4, text-figs 3, 4; Palmer \& Halley, 1979, p. 79, pl. 16 , figs $6-8,11-19$

Glossopleura expansa Poulsen (in part), 1927, p. 269, pl. 16, fig. 32

Glossopleura longifrons Poulsen (in part), 1927, p. 272, pl. 17 , fig. 10

Lectotype. Cranidium, MGUH 2277, designated by Poul$\operatorname{sen}(1964$, p. 26).

New material. Twenty-five sclerites in GGU 298971298973.

Remarks. Sclerites of $G$. walcotti are common in several sections in North Greenland. Morphological variation in this species has been discussed by Poulsen (1964, pp. 25-27), who also reassigned specimens previously referred to other species. New specimens of Glossopleura from Nyeboe Land all fall within the limits of variation of G. walcotti as outlined by Poulsen (1964).

Occurrence. $G$. walcotti is widespread in open-shelf lithofacies of the Glossopleura Assemblage-zone in North Greenland and the western United States. New material is from wackestone approximately $42 \mathrm{~m}$ above the base of the Henson Gletscher Formation at locality 1, Nyeboe Land. The species has been previously reported from the Cape Wood Formation of North-West Greenland (Poulsen, 1927; Poulsen, 1964) and the Carrara Formation of Nevada and California (Palmer \& Halley, 1979).

\section{Family Dorypygidae Kobayashi Genus Kootenia Walcott, 1889}

Bathyuriscus (Kootenia) Walcott, 1889, p. 446

Kootenia Walcott. Walcott, 1918, p. 131; Walcott, 1925, p. 92; Kobayashi, 1935, pp. 156, 192; Resser, 1937b, p. 15; Resser, 1938, p. 84; Deiss, 1939, p. 100; Resser, 1939a, p. 15; Resser, 1939b, p. 46; Lermontova, 1940, p. 139; Resser, 1942, p. 27; Howell, 1943, p. 244; Shimer \& Shrock, 1944, p. 613; Resser, 1945, p. 199; Rasetti, 1948a, p. 14; Rasetti, 1948b, p. 332; Thorslund, 1949, p. 4; Lermontova, 1951, p. 122; Rasetti, 1951, p. 188; Lochman in Cooper et al., 1952, p. 121; Hupé, 1955, p. 9; Palmer, 1954, p. 64; Ivshin, 1953, p. 37; Lochman, 1956, p. 1390; Poulsen in Harrington et al., 1959b, p. O218; Suvorova \& Pokrovskaia in Chernysheva, 1960, p. 78; Lermontova, 1951, pp. 122-124; Chernysheva, 1961, p. 126; Lazarenko, 1962, p. 60; Termier \& Termier, 1950, pl. 187 , figs 3, 4; Suvorova, 1964, pp. 86-90; Demokidov \& Lazarenko, 1964, p. 2041; Egorova et al., 1960, p. 192; Fritz, 1972, p. 35; Young \& Ludvigsen, 1989, p. 17

Dorypyge Matthew, 1899 , p. 56

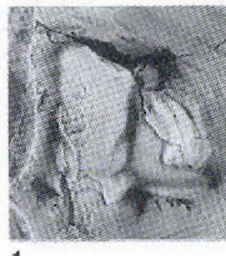

1

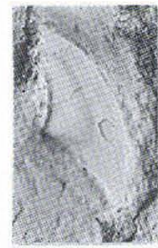

2

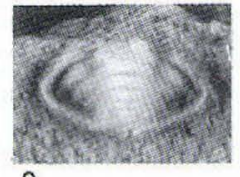

3

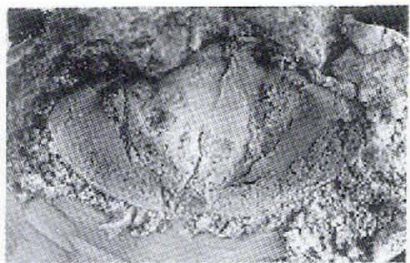

5

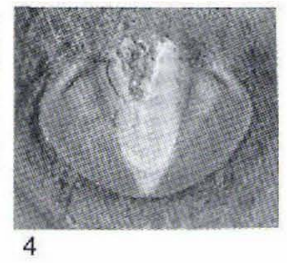

4

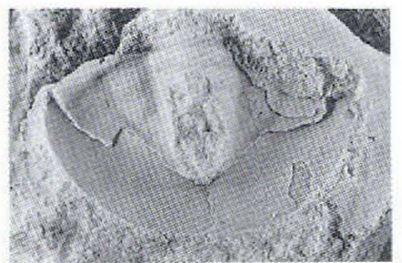

6
Fig. 12. Glossopleura walconi Poulsen. All specimens from GGU 298971, unless otherwise stated. 1, incomplete cranidium, MGUH 21.252, × 2.5. 2 , librigena, MGUH 21.253, × 3. 3, smallest observed pygidium, MGUH 21.254, × 16. 4, small pygidium, MGUH 21.255, × 8. 5, pygidium, MGUH 21.256 from GGU 298972, × 3. 6, pygidium, partly exfoliated, MGUH 21.257, × 2.5 . 
Notasaphus Gregory, 1903, p. 155; Whitehouse, 1939, pp. 241243

Type species. Bathyuriscus (Kootenia) dawsoni Walcott, 1889 , p. 446 , by original designation.

Remarks. The generic diagnosis of Palmer (1968, pp. B47, B48) is followed here.

\section{Kootenia nodosa n. sp.}

Fig. 13

Etymology. From Latin, nodus, swelling, referring to the median axial nodes on the pygidium.

Holotype. Pygidium, MGUH 21.258.

Material. More than 40 sclerites in GGU 298970298973.
Diagnosis. Kootenia having moderately elongate cranidium. Glabella slightly expanding anteriorly; lateral furrows weak. Pygidium having five rings, a terminal piece, and a postaxial ridge in the axis; each axial ring with a small median node; pleural field with five furrows and four weak interpleural furrows; margin with six pairs of subequally spaced spines, first pair short and slender, others short and moderately wide.

Description. Cranidium moderately elongate, wellrounded anteriorly. Glabella strongly convex, slightly expanding anteriorly, slightly constricted at S1, distinctly constricted in front of fossulae; lateral glabellar furrows shallow, $\mathrm{S} 1$ geniculate, S2 transverse. Occipital ring with strong median spine. Anterior border narrow in front of glabella, slightly wider at sides. Anterior area of fixigena reduced to narrow depression between border and eye ridge. Eye ridge distinct. Posterior area of fixigena slightly more than one-half glabellar width. Palpebral lobe moderately long in small specimens but incomplete in large specimens. Surface with fine, densely spaced
Fig. 13. Kootenia nodosa n. sp. All specimens from GGU 298970.

1 , holotype pygidium in dorsal (a) and right-lateral (b) views, MGUH $21.258, \times 5.2$, latex cast of weathered pygidium, MGUH 21.259, × 4. 3, latex cast of incomplete pygidium, MGUH $21.260, \times 5.4$, small cranidium, MGUH 21.261, × 8. 5, small cranidium, MGUH 21.262, $\times$ 5. 6, labrum, MGUH 21.263, × 7; pygidium of Glossopleura walcotti Poulsen in lower right of photograph is the same specimen illustrated in Fig. 12.3. 7, librigena, MGUH $21.264, \times 5.8$, large, incomplete cranidium, MGUH $21.265, \times 4.5$.

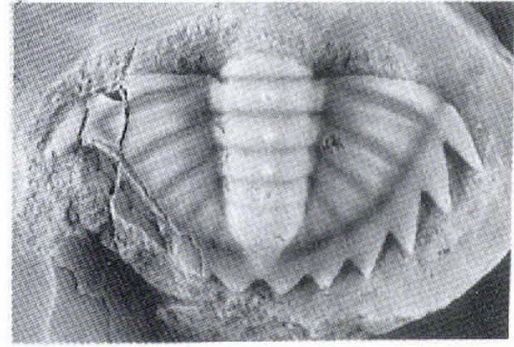

$1 \mathrm{a}$

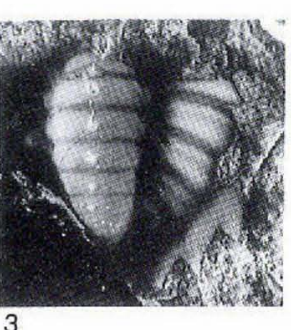

3

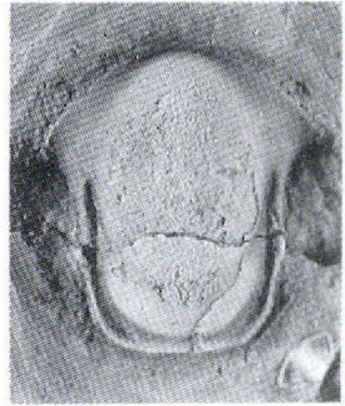

6

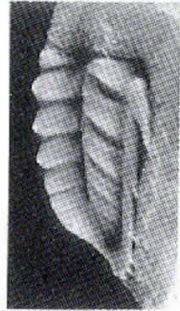

$1 \mathrm{~b}$
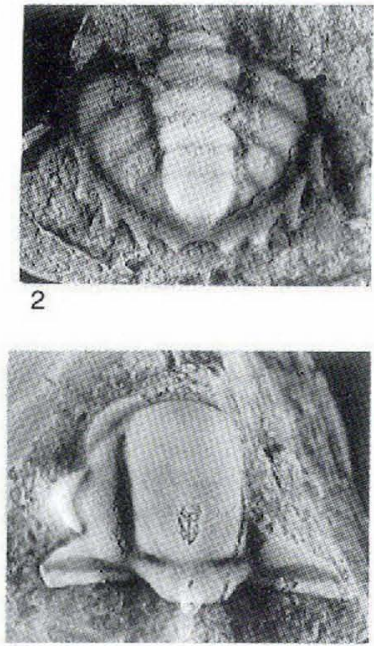

5

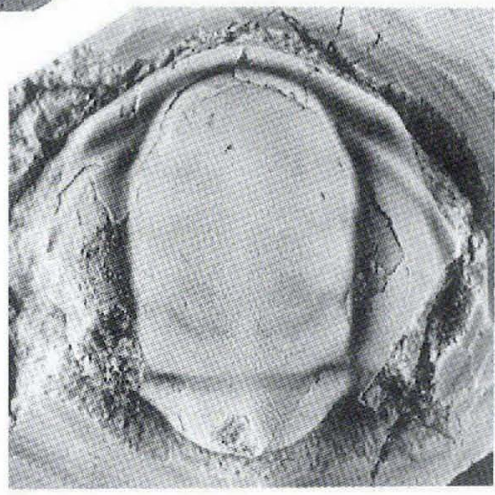

7
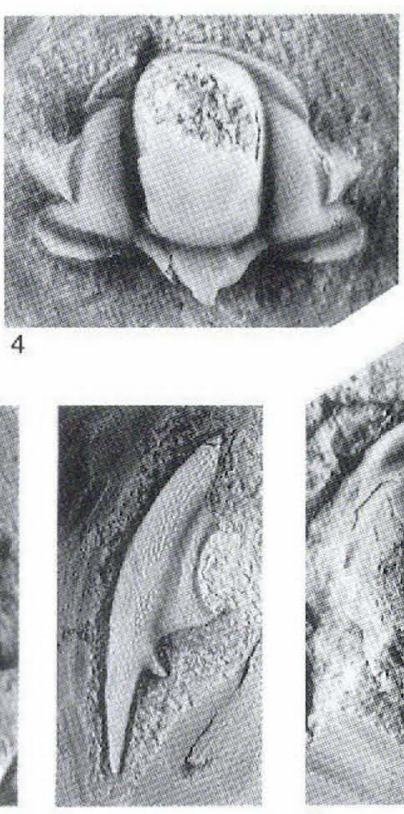

4 
granules except in furrows and on anterior border; anterior border with terrace lines that parallel margin.

Thorax unknown.

Pygidium semicircular except for marginal spines. Axis convex, elevated well above pleural field, moderately tapering, having five rings, terminal piece, and short postaxial ridge extending to posterior margin; ring furrows shallowing posteriorly; each axial ring with small median node, decreasing in size posteriorly. Pleural field slightly convex, having five furrows that shallow posteriorly and four weak interpleural furrows. Border furrow shallow, wide. Margin with six pairs of spines, subequally spaced; first pair short and slender, remaining spines short, nearly uniform in length, moderately wide. Surface with fine, densely spaced granules except in furrows.

Remarks. Numerous species of Kootenia have been described from various localities worldwide but none is particularly similar to $K$. nodosa in the combination of pygidial characters. $K$. nodosa has a distinctive pygidium with five rings in the axis, each with a small median node of variable expression. Six pairs of short marginal spines are present. The first pair is slender and the rest are moderately wide. Another distinctive character of the pygidium is that five pairs of furrows and four pairs of weak interpleural furrows are present in the pleural region.

Occurrence. Common in wackestone approximately 42 m above the base of the Henson Gletscher Formation at locality 1 , Nyeboe Land. It is associated with polymeroids indicative of the Glossopleura Assemblage-zone.

\section{Genus Olenoides Meek, 1877}

Olenoides Meek, 1877, p. 25; Kobayashi, 1935, pp. 152-154 (for synonymy to 1935); Lermontova, 1940, p. 138; Shimer \& Shrock, 1944, p. 613; Ivshin, 1953, p. 37; Palmer, 1954, pp. 62, 63; Poulsen in Harrington et al., 1959b, p. O218; Robison, 1964, p. 537; Robison, 1971, p. 799; Robison, 1988, p. 64; Young \& Ludvigsen, 1989, p. 19

Neolenus Matthew, 1899 , p. 52 (see Kobayashi, 1935 for synonymy to 1935); Lake, 1938, p. 260

Type species. Paradoxides(?) nevadensis Meek, 1870, p. 62, by original designation (Meek, 1877, p. 25).

Remarks. The generic diagnosis of Robison (1964, p. 537) is followed here.

\section{Olenoides sp.}

Fig. 14.1

Material. One nearly complete pygidium and one nearly complete cranidium, plus several cranidial and pygidial fragments, in GGU 298970.

Remarks. A distinctive species of Olenoides is represented by sclerites in GGU 298970. The cranidium is

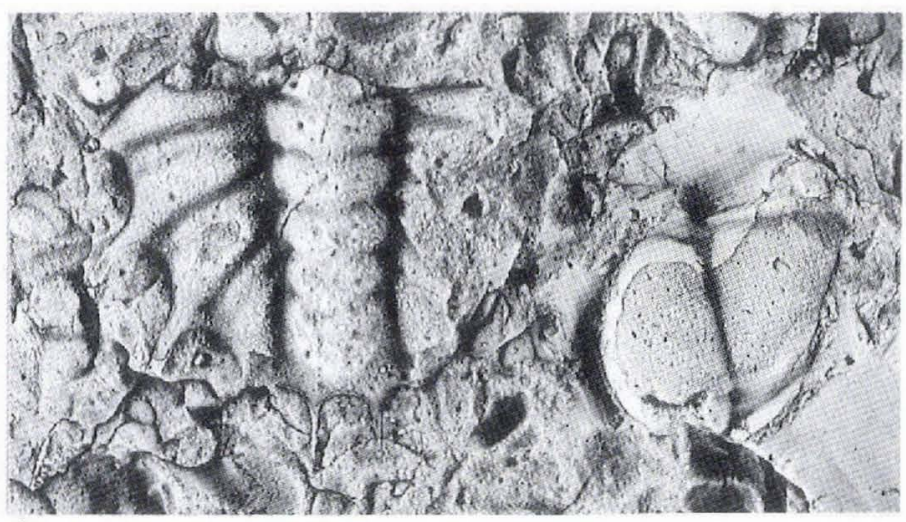

1

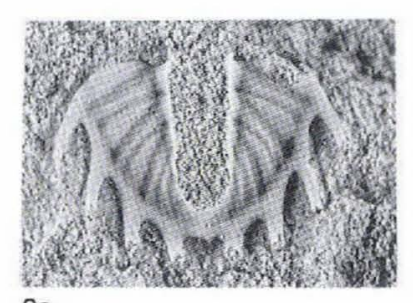

$2 a$

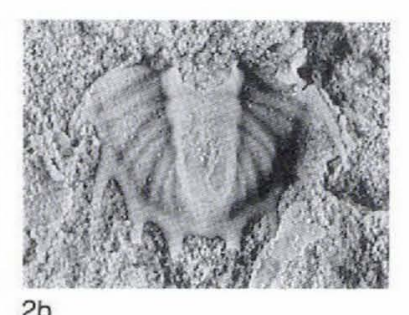

$2 \mathrm{~b}$
Fig. 14. Specimens of Olenoides.

1, Olenoides sp. Weathered bedding surface with broken pygidium (left), MGUH 21.266, and broken cranidium (right), MGUH 21.267, from GGU $298970, \times 2$.

2, Olenoides cf. O. convexus Rasetti; pygidium (a) and latex cast of counterpart (b), MGUH 21.268 from GGU 319789 (a) and 319790 (b), $\times 8$. 
known from only fragmentary, partially exfoliated specimens. The glabella is anteriorly expanding, moderately convex, and elevated well above the fixigena. It extends well past the anterolateral corner of the cranidium, and is unfurrowed except for a short, weak depression extending from each fossula. The occipital furrow is distinct. The occipital ring is broken, but evidently bore a medial spine. The fixigena is wide for the genus. Both the axial furrows and eye ridges are distinct. Surface prosopon appears to have been lacking except for terrace lines that parallel the margin, and which are present only on the anterior border.

The thorax is unknown, and the pygidium is known from only incomplete, exfoliated specimens. The axis is elevated well above the pleural field, and contains four rings and a long terminal piece. It is slightly tapered posteriorly, and has a minor constriction at the fourth ring. The ring furrows are strong. The first two axial rings both have a small median node. Other rings may have had median nodes, but all the specimens are broken. The pleural field is moderately convex, and has three strong, wide pleural furrows, and three weak interpleural furrows. Both pleural furrows and interpleural furrows become slightly shallower posteriorly. Marginal spines consist of five pairs that are subequally spaced and posteroradially disposed. The first four pairs evidently were long and slender. The last pair is moderately long, and about one-half the width of the preceding spines. Surface prosopon has not been observed.

Four described species of Olenoides have five pairs of marginal spines. They are O. serratus (Rominger, 1887) from the Stephen Formation of British Columbia and possibly boulder L-9, Ville Guay, Quebec (Rasetti, 1948b), O. decorus Resser, 1942, from the Marjum Formation of Utah, O. superbus (Walcott, 1908) from the Marjum Formation of Utah, and $O$. aptus Suvorova, 1964, from Siberia. The pygidium of the species from North Greenland most closely resembles the pygidium of $O$. serratus. It differs from both $O$. serratus and $O$. decorus in having longer marginal spines, a shorter terminal piece in the axis, and shallower interpleural furrows. It differs from $O$. superbus in having marginal spines of different lengths and two or three fewer axial rings. Differences in the pygidium that distinguish it from $O$. aptus are somewhat narrower pleural lobes, deeper pleural and interpleural furrows, a longer terminal piece in the axis, and marginal spines that project more radially.

Occurrence. Present in a packstone bed from approximately $56 \mathrm{~m}$ above the base of the Henson Gletscher Formation at locality 1, Nyeboe Land. It is associated with trilobites of the Ptychagnostus gibbus Interval-zone of Robison (1984).

\section{Olenoides cf. O. convexus Rasetti, 1948b}

Fig. 14.2

Olenoides convexus Rasetti, 1948b, p. 338, pl. 51, figs 5-9

Material. Two pygidia, one in GGU 319790, the other in GGU 319789 (part) and 319790 (counterpart).

Remarks. Two new pygidia are compared with Olenoides convexus Rasetti, 1948b, which was previously known from only boulder G-6, of Middle Cambrian age, from Grosses Roches, Quebec. An associated cranidium was not found. The best preserved pygidium (Fig. 14.2) is complete except for the ends of its marginal spines. It differs slightly from Rasetti's figured specimens in having marginal spines that are subequally spaced instead of slightly increasing in separation posteriorly. The ring furrows of both specimens are less well impressed than on specimens illustrated from Quebec. Characters of the pygidium that are diagnostic of $O$. convexus, including the presence of four pleural furrows, three interpleural furrows, and four pairs of marginal spines, each of which is offset slightly forward of its corresponding pleural furrow and is upwardly curved distally, are all present on the new specimens.

Occurrence. New material is from a packstone bed of the basal Kap Stanton Formation at locality 2, Nyeboe Land. It is associated with trilobites indicative of the Ptychagnostus atavus Interval-zone of Robison (1984).

\section{Family Menomoniidae Walcott Genus Bolaspidella Resser, 1937}

Bolaspidella Resser, 1937b, p. 3; Robison, 1964, pp. 552-554 (for synonymy to 1964); Robison, 1971, p. 801; Shaw, 1966, p. 292; Palmer, 1968, p. B66; Öpik, 1967, p. 367; Öpik, 1970, p. 44; Shah \& Sudan, 1982, p. 237; Robison, 1988, p. 79 Hysteropleura Raymond, 1937, p. 1094; Shaw, 1966, p. 290

Type species. Ptychoparia housensis Walcott, 1886, by original designation (Resser, 1937b, p. 3).

Remarks. Robison $(1964,1971,1988)$ discussed the concept and content of Bolaspidella. That generic concept is followed here.

\section{Bolaspidella sp.}

Fig. 15

Material. One cranidium in GGU 298970.

Remarks. A single, small, mostly exfoliated cranidium is 


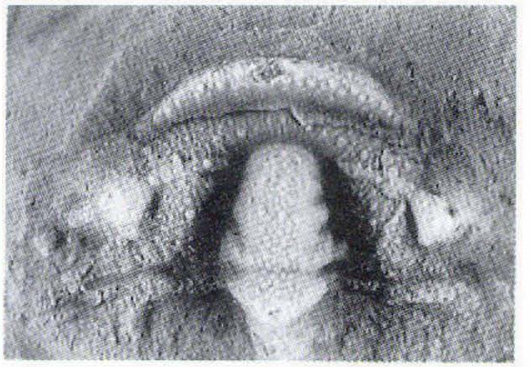

Fig. 15. Bolaspidella sp.; cranidium, mostly exfoliated, MGUH 21.269 from GGU 298970, $\times 10$.

present in GGU 298970. Identification of the specimen to species is deferred until more material is available. The glabella is moderately tapered and bluntly rounded at the front. Three pairs of lateral glabellar furrows are well developed. Medially, the occipital ring is wide, and has a broken spine base. The anterior border is wider than the preglabellar field. The palpebral lobes are moderately long and located opposite the glabellar midpoint. Anteriorly, the facial suture is strongly convergent, and posteriorly, it is strongly divergent. Granules of bimodal size cover the entire cranidium, except in the furrows, and type 4 caeca radiate from the anterior and anterolateral areas of the axial furrow into the preglabellar field.

Occurrence. From a packstone bed approximately $56 \mathrm{~m}$ above the base of the Henson Gletscher Formation at locality 1, Nyeboe Land. It is associated with trilobites of the Ptychagnostus gibbus Interval-zone of Robison (1984).

\section{Family Ogygopsidae Rasetti Genus Ogygopsis Walcott, 1889}

Ogygopsis Walcott, 1889, p. 466; Miller, 1892, p. 710; Grabau \& Shimer, 1910, p. 289; Walcott, 1916, pp. 375, 376; Raymond \& Walcott, 1937, p. 718; Shimer \& Shrock, 1944, p. 613; Rasetti, 1951, p. 190; Rasetti in Harrington et al., 1959b, p. O219; Nelson, 1963, pp. 244-247; Palmer, 1964, pp. F6, F7; Young \& Ludvigsen, 1989, p. 19

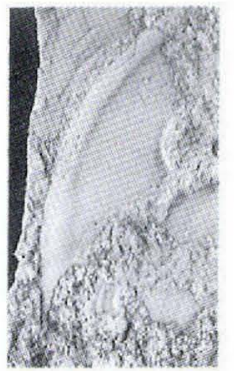

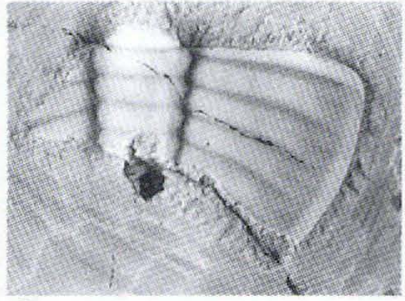

2

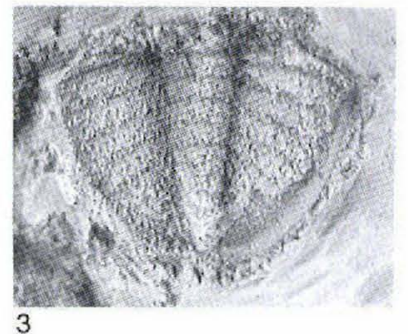

3
Taxioura Resser, 1939b, p. 62; Shimer \& Shrock, 1944, p. 617; Egorova et al., 1960, p. 187

Type species. Ogygia klotzi Rominger, 1887, by original designation (Walcott, 1889, p. 466).

Remarks. The diagnosis of Ogygopsis followed here is that of Palmer (1964), who also provided a brief differential diagnosis of each species.

\section{Ogygopsis klotzi (Rominger, 1887) \\ Fig. 16}

Ogygia klotzi Rominger, 1887, p. 12, pl. 1, fig. 1

Ogygia? klotzi Walcott, 1888, p. 166

Ogygopsis klotzi Walcott, 1889, p. 446; Woodward, 1902, p. 530, text-fig. 1; Walcott, 1908, pl. 4, fig. 4; Grabau \& Shimer. 1910, p. 289, fig. 1597; Walcott (in part), 1916, pp. 377, 378, pl. 66, figs 1, 1a (not 1b); Raymond \& Walcott, 1937, fig. 1382; McLaughlin \& Enbysk, 1950, p. 470, pl. 65, fig. 1; Rasetti, 1951, pp. 191, 192, pl. 12, figs 1-5, pl. 21, figs 1-3, pl. 29, figs 6-8; Rasetti in Harrington et al., 1959b, p. O219, fig. 160,I; Nelson, 1963, pp. 244, 247; Palmer, 1964, pp. F6, F7; Hofmann \& Parsley, 1966, pp. 209-211, text-fig. 2; Gupta (in part), 1967, p. 276, figs 1-3, 5, 9 (not 6); Campbell, 1971, pp. 437-440, pl. 52, figs 11, 12; Rudkin, 1979, fig. la-h; McNamara \& Rudkin, 1984, pp. 164-168, figs 9, 10; Young \& Ludvigsen, 1989, pp. 19, 20, pl. 5, fig. 11, pl. 6, figs 1-4, fig. 6C: Talent, 1990, p. 405

Ogygia (Ogygopsis) klotzi Rominger. Matthew, 1899, pp. 58, 59

?Taxioura elongata McLaughlin \& Enbysk, 1950, pp. 470, 471, pl. 65 , figs 2,9

?Taxioura? sp. McLaughlin \& Enbysk, 1950, p. 471, pl. 65, fig. 3

Ogygopsis klotzi? Stoyanow, 1958, pp. 349, 350, pl. 1, fig. 2

Holotype. Philadelphia Academy of Natural Sciences (fide Rasetti, 1951, p. 192), number unknown.

New material. One cranidium, two pygidia, and one librigena in GGU 298971-298973.

Remarks. New specimens of Ogygopsis from Nyeboe Land conform in all observed characters with figured or
Fig. 16. Ogygopsis klotzi (Rominger). All specimens from GGU 298971. 1, latex cast of librigena, MGUH $21.270, \times 2$. 2, broken pygidium, MGUH 21.271, × 3.3, weathered pygidium, MGUH 21.272, × 3 . 
examined specimens of $O$. klotzi from the Stephen Formation of British Columbia. The new specimens are all holaspides but are small compared to the maximum size obtained by specimens from British Columbia. Pygidia from Nyeboe Land have relatively weaker interpleural furrows than those from British Columbia. This character is variable, and probably influenced by compaction, and it is not considered to have taxonomic significance.

Specimens described by McLaughlin \& Enbysk (1950) as Taxioura elongata and Taxioura? sp. from the Metalline Limestone of Pend Oreille County, Washington seem to belong to $O$. klotzi, judging from published illustrations. O. klotzi was also described from the Metalline (McLaughlin \& Enbysk, 1950, p. 470), and I tentatively consider the three forms to be synonyms.

Occurrence. From wackestone approximately $42 \mathrm{~m}$ above the base of the Henson Gletscher Formation at locality 1, Nyeboe Land. Other unquestioned reports of O. klotzi are from British Columbia (Rasetti, 1951, pp. 191, 192), California, Nevada and Washington (Nelson, 1963, p. 247), Pennsylvania (Campbell, 1971, pp. 437, 438 ), and western Newfoundland (Young \& Ludvigsen, 1989 , pp. 19, 20). The total observed range of $O$. klotzi is from the upper part of the Olenellus Assemblage-zone to the Oryctocephalus Assemblage-zone (upper Ptychagnostus praecurrens Interval-zone of Robison, 1984). Nelson's (1963) statement that $O$. klotzi ranges into the upper Middle Cambrian seems to be erroneous.

A report of $O$. klotzi from Zachaldor, Kashmir, India (Gupta, 1967), seems to be in error. Talent (1990) demonstrated that five of six of Gupta's figures were copied from Rasetti (1951). The other figure (Gupta, 1967, fig. 6) appears to be part of the axial lobe of an indeterminate trilobite, but the axial rings are too narrow for the specimen to belong to Ogygopsis.

\section{Family Paradoxididae Hawle \& Corda}

Remarks. Numerous discussions of the classification and evolution of paradoxidid trilobites have been published over the last 70 years. Some important opinions include those expressed by Howell (1933), Whitehouse (1939), Westergård (1950), Šnajdr $(1957,1958)$, Poulsen (in Harrington et al., 1959b), Öpik (1961), and Bergström and Levi-Setti (1978).

Six genera of the family Paradoxididae (sensu Poulsen in Harrington et al., 1959b) and two genera of the family Protolenidae (sensu Henningsmoen in Harrington et al., 1959b), which are putatively closely related (Öpik, 1961), were analyzed cladistically using PAUP (Phylogenetic Analysis Using Parsimony; Swofford, 1989) to de-

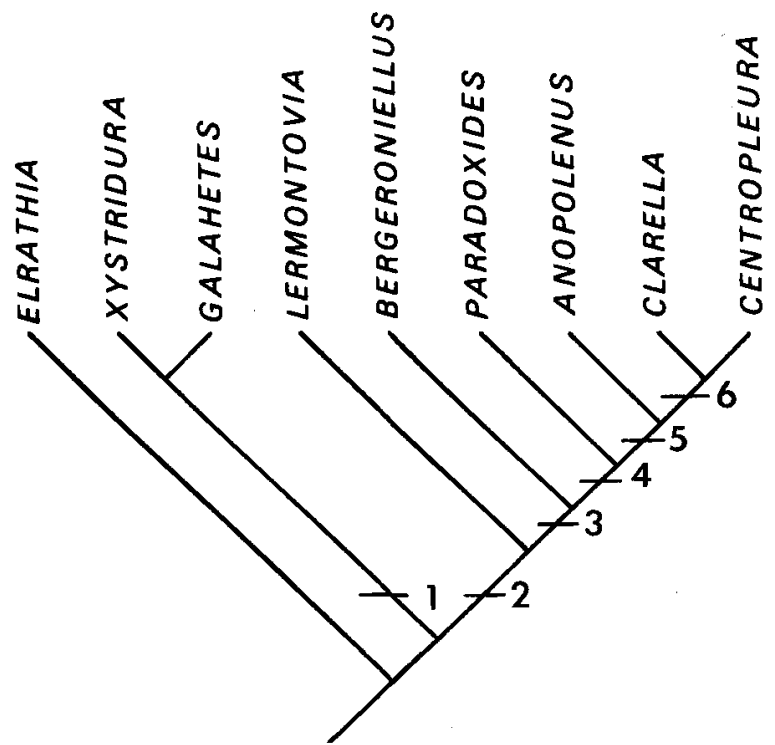

Fig. 17. Cladogram illustrating hypothesized phylogenetic relationships among selected genera of the family Paradoxididae, based on characters preserved in holaspides. Elrathia is used as the outgroup. Characters represented by character bars (numbered) are explained in the text.

termine phylogenetic relationships among the taxa. The analyzed paradoxidids and protolenids are inferred to be a monophyletic (holophyletic) group (Fig. 17) united by the shared derivation of a distinctive, elongate palpebral lobe. Here, this monophyletic group is treated as the family Paradoxididae Hawle \& Corda, 1847. It embraces, but is not restricted to, the genera Xystridura, Galahetes, Lermontovia, Bergeroniellus, Paradoxides, Anopolenus, Clarella, and Centropleura. Analyses were performed on a data matrix (Table 2) of equally weighted characters expressed in holaspides. All genera analyzed are known from relatively complete specimens. Paradoxides was used as a proxy for the group that also includes Acadoparadoxides, Eccaparadoxides, Hydrocephalus, and Eoparadoxides. Where there was ambiguity about character states present in a genus, characters in only the type species were analyzed. Transformation states were polarised using Elrathia as the primitive outgroup.

An exhaustive search of genera in the Paradoxididae yielded one most parsimonious tree (Fig. 17). Within the Paradoxididae, two major clades seem to have arisen. One, the subfamily Xystridurinae Whitehouse, 1939, includes Xystridura and Galahetes. This group is united by the shared acquisition of a macropleural segment that is ankylosed to the pygidium rather than being shed forward into the posterior thorax as in other paradoxidids (Fig. 17, character bar 1). A large rostral plate is present in both Xystridura and Galahetes. It is either homoplasic with the 


\section{Table 2. Characters used to express relationships among paradoxidid trilobites}

Characters and character states used to construct the cladogram expressing inferred relationships among paradoxidid trilobites (Fig. 17). Character states are those of holaspid specimens. A question mark indicates missing data.

1. Anterior glabella: not expanded (0); slightly expanded (1); greatly expanded (2).

2. Confluent $S 1$ lateral glabellar furrow: absent $(0)$; present (1).

3. Number of lateral glabellar furrows: $4(0) ; 3$ (1);2 (2); 0 (3).

4. Anterior glabellar furrow: transverse (0); longitudinal (1).

5. Anterior branch of facial suture: divergent $(0)$; retrodivergent (1).

6. Size of pygidium: small (0); micropygous (1); macropygous (2).

7. Number of pleurae in pygidium: greater than or equal to 3 (0); less than 3 (1).

8. Number of thoracic segments: less than or equal to $13(0)$; 14 to $15(1) ; 16(2) ; 17$ to 21 (3).

9. Size of rostral plate: medium (0); large (1); small (2).

10. Anterolateral spines on labrum: absent (0); present (1).

11. Pygidial border: present (0); absent (1).

12. Curvature of palpebral lobes: even $(0)$; uneven (1).

13. Length of palpebral lobes: short (0); moderately long (1); very long (2); to rear of cranidium (3).

14. Metafixigenal spines: absent (0); present (1).

15. Macropleural segment in anterior thorax: absent $(0)$; present (1).

16. Width of pleurae: wide $(0)$; moderately reduced (1); much reduced (2).

17. Macropleural segments in posterior region: absent (0); ankylosed to pygidium (1); shed into thorax (2).

18. Eye ridges: present (0); absent (1).

19. Length of genal spines: less than or equal to one-half of body length (0); greater than one-half of body length (1)

20. Pleural lobes: convex (0); flat (1).

21. Axial spine in thorax: absent (0); present (1).

22. Preoccipital ridge: absent (0); present (1)

23. Medial nodes on pygidial axis: absent (0); present (1).

24. Maximum holaspid length: less than $7 \mathrm{~cm}(0)$; equal to or greater than $7 \mathrm{~cm}$ (1).

\begin{tabular}{lrrrrr}
\hline Genera & \multicolumn{5}{c}{ Characters } \\
& & 1 & 11111 & 11112 & 2222 \\
& 12345 & 67890 & 12345 & 67890 & 1234 \\
\cline { 2 - 6 } & & & & & \\
Cenathia (outgroup) & 00000 & 00000 & 00000 & 00000 & 0000 \\
Xystridura & 21011 & 20210 & 11210 & 22111 & 0001 \\
Paradoxides & 10100 & 00011 & 10100 & 01000 & 0000 \\
Bergeroniellus & 21200 & 11301 & 10101 & 10100 & 0001 \\
Lermontovia & 00000 & $111 ? 1$ & 10100 & 10000 & 0000 \\
Anopolenus & 00100 & $113 ? ?$ & 00100 & 00000 & 1100 \\
Clarella & 11011 & $201 ? ?$ & 10300 & $221 ? 1$ & 0001 \\
Galahetes & 21011 & $201 ? ?$ & 11310 & $221 ? 1$ & 0001 \\
\hline & 20100 & $0001 ?$ & 10110 & 01000 & 0010 \\
\hline
\end{tabular}

rostral plate of Centropleura or symplesiomorphic. The sister group of the xystridurines includes the paradoxidines Lermontovia, Bergeroniellus, Paradoxides, Anopolenus, Clarella, and Centropleura. Previously, Lermontovia and Bergeroniellus were assigned (Henningsmoen in Harrington et al., 1959b) to the subfamily Protoleninae Richter \& Richter, 1948 of the family Protolenidae Richter \& Richter, 1948 and Anopolenus, Clarella, and Centropleura were assigned to the subfamily Centropleurinae Angelin, 1854, of the family Paradoxididae. Herein, all these genera are considered to belong in the subfamily Paradoxidinae Hawle \& Corda, 1847. The group shares an increased number of thoracic segments (14 or more), which is interpreted to be a peramorphic character (Fig. 17, character bar 2).

The subfamily Centropleurinae Angelin, 1854, with Centropleura as the nominal genus, is here considered to be a junior synonym of Paradoxidinae Hawle \& Corda, 1847. Although Anopolenus, Clarella, and Centropleura seem to constitute a monophyletic group, retention of separate formal status for that group would result in the use of the name Paradoxidinae for a paraphyletic group including Lermontovia, Bergeroniellus, and Paradoxides.

Each of the character bars numbered 2 to 6 (Fig. 17) is supported by at least one character, although some characters are probably reductions from the inferred primitive condition for the paradoxidids. Character bar 2 represents the shared acquisition of 14 or more thoracic segments and a small pygidium. Character bar 3 represents a reduction in width of the pleurae. Character bar 4 represents the acquisition of a confluent $S 1$ lateral glabellar furrow. The loss of eye ridges at this stage is probably an expression of paedomorphosis, but the heterochronic process that led to an increase of the adult length to greater than 7 $\mathrm{cm}$ is equivocal. Character bar 5 represents the acquisition of a longitudinal anterior glabellar furrow, a retrodivergent expression of the anterior branch of the facial suture, a backward extension of the palpebral lobe near or to the posterior border furrow (possibly through paedomorphosis), and the shedding of macropleural segments forward into the posterior thorax (probably an expression of peramorphosis). Other characters at character bar 5 are extreme reductions in width and convexity of the thoracic pleurae. Character bar 6 represents the acquisition of metafixigenal spines in holaspides. The character arose through paedomorphosis and was probably independently derived in Galahetes. That it arose through paedomorphosis is evident from the appearance of metafixigenal spines in the early ontogeny of Xystridura, Galahetes, and Centropleura and its loss in the later ontogeny of Xystridura. Extensive ontogenetic sequences are not known for either Anopolenus or Clarella, but it is 
inferred that they share basic similarities with the ontogeny of Centropleura.

\section{Genus Centropleura Angelin, 1854}

Centropleura Angelin, 1854, p. 87; Angelin, 1878, p. 87; Lindström, 1901, pp. 16, 24, 49; Grönwall, 1902, pp. 122, 123; Illing, 1916, p. 430; Howell, 1933, p. 216; Howell, 1937, p. 1170; Lake, 1934, pp. 187-189; Lermontova, 1940, p. 135; Shimer \& Shrock, 1944, p. 609; Westergård, 1950, pp. 3, 4; Poulsen in Harrington et al., 1959b, p. O214; Öpik, 1961, p. 99; Lermontova in Chernysheva, 1960, p. 71; Suvorova, 1960 , p. 71 ; Rasetti, 1967 , p. 90

Anopolenus Salter. Kobayashi, 1935, p. 126

Luhops Snajdr (in part), 1957, pp. 239, 244; Šnajdr (in part), 1958, pp. 152-153

Type species. Paradoxides loveni Angelin, 1851, p. 2, by monotypy (Angelin, 1854, p. 87).

Emended diagnosis. Cephalon semiparabolic in dorsal outline. Cranidium flattened except for strongly convex axis; anterior border wide, upturned; posterolateral corner rounded, usually with metafixigenal spine. Glabella strongly convex, forwardly expanding; S1, S2, S3 transverse, S4 oblique backward; L4 triangular. Palpebral lobe long, thin, arcuate, unevenly curved. Fixigena flat except for slightly raised genal bar and palpebral lobe. Librigena narrow; genal spine long, curved, divergent. Facial suture retrodivergent on anterior branch; broadly arcuate, divergent at eye; posterior branch concave, cutting posterior border between genal and metafixigenal spines. Labrum subquadrate, anterior border strongly curved, anterior wings short, posterior wings short to long. Rostral plate large, broadly curved, narrow medially and widening distally.

Thorax having 16 segments, strongly convex axially, flattened pleurally. Axial furrow well defined. Segments 1 to 13 narrower than cranidium; axial rings wide, convex; pleural furrows shallow, oblique; segments terminating in short to moderately long pleural spines. Segments 14 to 16 hypertrophic, falcate.

Pygidium short, wide, flattened except for axis. Pleural field wide, having 2 or 3 pairs of short marginal spines.

Remarks. Westergård (1950) reviewed the taxonomic history of Centropleura and the closely related genera Anopolenus and Clarella. Although the morphological differences among these taxa seem to be relatively minor, I continue to recognise each as an independent genus rather than recognising Anopolenus and Clarella as subgenera of Centropleura as Öpik (1961) did. Śnajdr (1957) erected the paradoxidid genus Luhops with Paradoxides expectans Barrande, 1852, as the type species. Öpik
(1961, pp. 103, 104), however, indicated that Šnajdr had combined cranidia of Paradoxides or Hydrocephalus with pygidia and a thorax of Centropleura in his concept of Barrande's (1852) species. After examination of casts of some of Snajdr's (1958) illustrated specimens (USNM 90831), I concur with Öpik's conclusion. Illustrated material of C. (Beishanella) beishanensis Xiang \& Zhang, 1985 , the type species of the subgenus, is not sufficient to determine whether or not continued use of the subgeneric name is warranted.

Centropleura was widespread during the Middle Cambrian, possibly because it had a pelagic lifestyle (see Fortey, 1985). Characters supporting a pelagic existence (Fortey, 1985; Babcock in press) include strongly reduced pleural areas, an inflated glabella, the presence of numerous terrace lines on the dorsal surface, large eyes, and elongate marginal spines. Dispersal and adaptive radiation in the genus are inferred to have taken place in marine waters below the thermocline.

As presently defined, Centropleura includes the species C. loveni (Angelin, 1851), from Scandinavia, Bennett Island, and North Greenland; C. angelini Westergård, 1950, from Sweden and possibly North Greenland and Tien Shan; C. angustata Westergård, 1950, from Sweden; C. belli Hutchinson, 1952, from Quebec; $C$. expectans Barrande, 1852, from Bohemia; C. keguqinensis Xiang \& Zhang, 1985, from Tien Shan; $C$. oriens Chernysheva, 1953, from Siberia; C. phoenix Öpik, 1961, from Queensland, Australia; C. pugnax Illing, 1916, from England; $C$. sibirica Lermontova, 1940, from Siberia; $C$. sonax Öpik, 1961, from Queensland, Australia; C. tianshanensis Xiang \& Zhang, 1985, from Tien Shan; and C. vermontensis Howell, 1932, from Vermont. C. (Beishanella) beishanensis Xiang \& Zhang, 1985 is from Tien Shan. C. neglecta Öpik, 1949, is known from only one fragmentary cranidium from Victoria, Australia. Evidence that it should be retained in Centropleura is inconclusive. Some other described occurrences of Centropleura include specimens unassigned to species from central Nevada (Stewart \& Palmer, 1967; Palmer \& Stewart, 1968; Babcock, 1990a), New York (Rasetti, 1967), the Altai region of Russia (Romanenko, 1985), Tasmania (Jago, 1972a, 1990), and northern Victoria Land, Antarctica (Cooper $e t$ al., 1976, 1983). Its observed stratigraphic range is from the Ptychagnostus atavus Zone to the Lejopyge laevigata Zone.

\section{Centropleura loveni (Angelin, 1851)}

Figs 18, 19, 20.1-6

Paradoxides loveni Angelin (in part), 1851, p. 2, pl. 3, figs 1-3 Centropleura loveni (Angelin). Angelin (in part), 1854, p. 87; Angelin (in part), 1878, p. 95, pl. 3, fig. 1, 1a; Grönwall, 


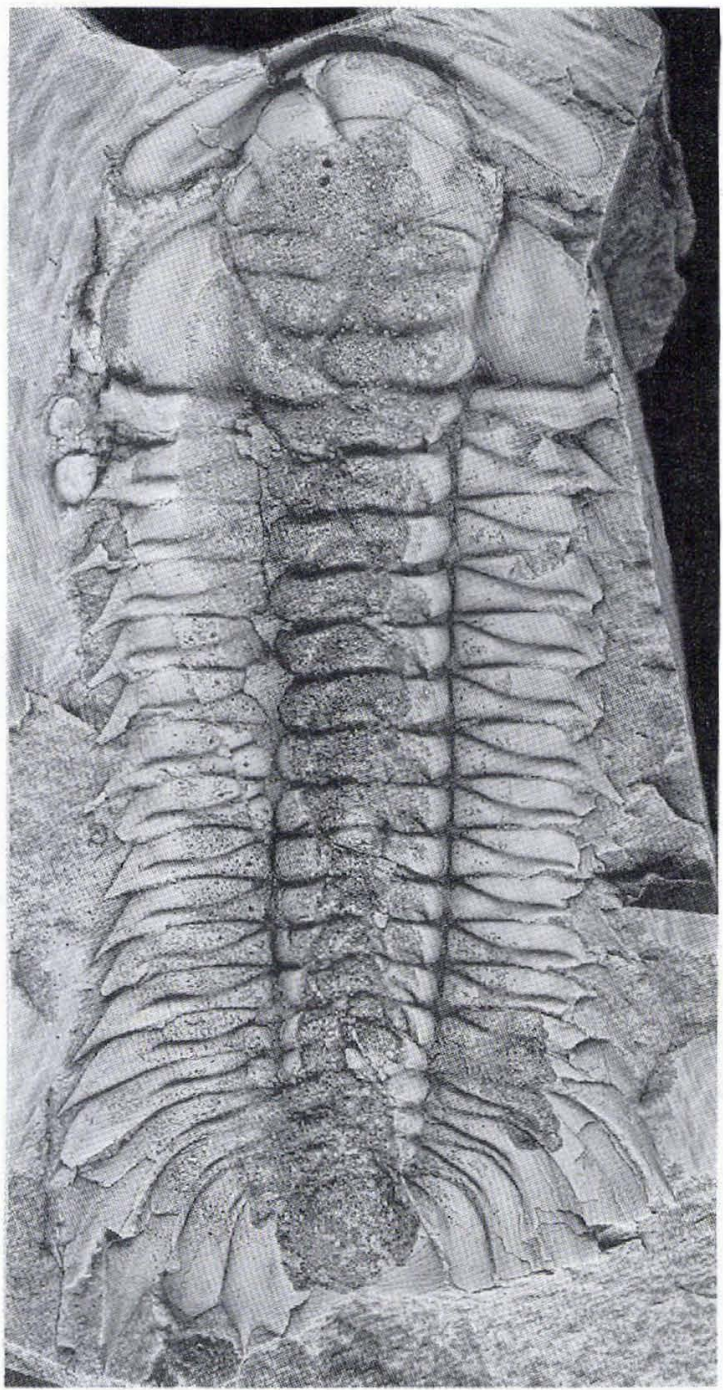

1

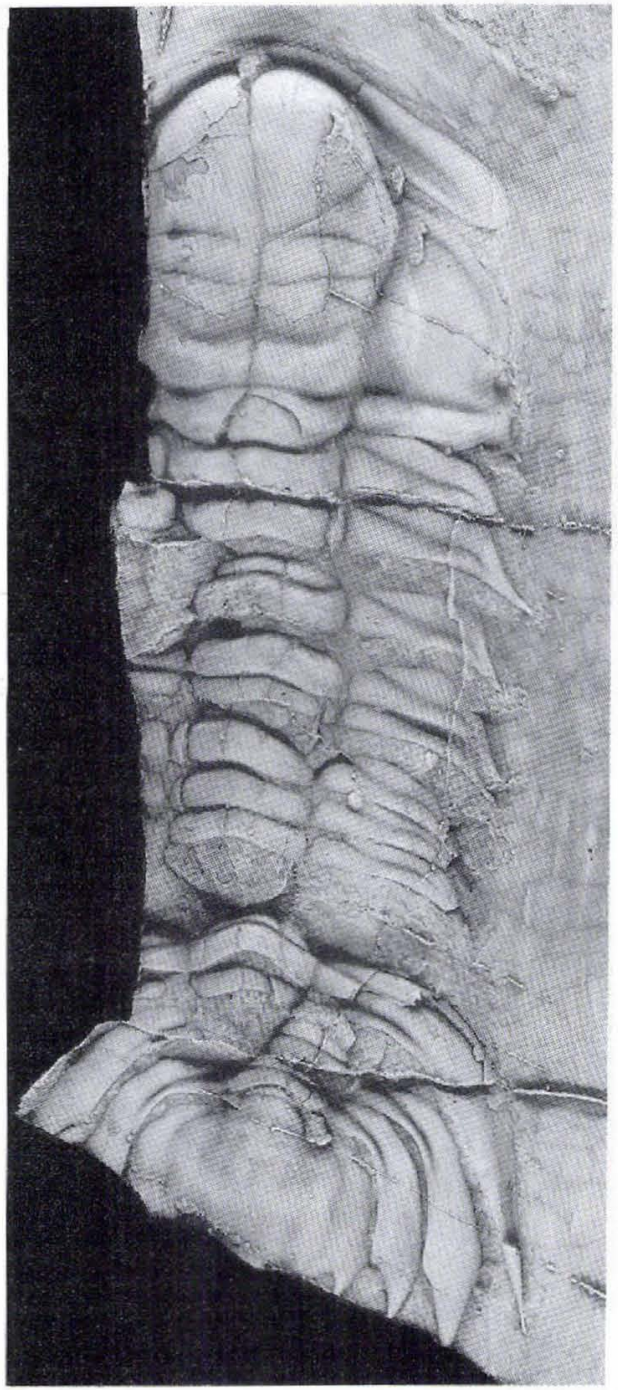

2

Fig. 18. Centropleura loveni (Angelin).

1, axial shield, weathered along the middle, MGUH 21.273 from GGU 301313, × 1.25; an agnostoid trilobite, Toragnostus bituberculatus (Angelin), is near the left side. 2, latex cast of slightly disarticulated axial shield, MGUH 21.083 from GGU 301312 , $\times 1.25$; a neoplasm (tumor) is on the right pleural area of the sixth thoracic segment (see Babcock 1993: figs 3.1, 3.2).

1902, pp. 124, 125; Lermontova, 1940, p. 135, pl. 41, figs 2-4; Holm \& Westergård, 1930, p. 16, pl. 3, figs 13-16, pl. 4, figs 24-25; Westergård (in part), 1950, pp. 4, 5, pl. 1, figs 1-3 (not 4), pl. 2, fig. 2?, (not 1); Poulsen (in part) in Harrington et al., 1959b, p. O214, fig. 154a (not 154b); Reyment (in part), 1980 , p. 7, fig. 15c (copy of Angelin, 1851, pl. 3, fig. 1) (not 15a?, 15b); Babcock, 1993, figs 3.1, 3.2

Centropleura angelini Westergård (in part), 1950, pp. 4-6, pl. I, fig. 10

Lectotype. Angelin (1851, p. 2) based the type species of Centropleura, Paradoxides loveni, on an unknown number of specimens now in the Swedish Museum of Natural History and the Paleontological Museum, Uppsala Uni- versity. His figures (Angelin, 1851, pl. 3, figs 1-3; one reproduced by Reyment, 1980, fig. 15c) of C. loveni are composites and include characters of C. loveni, $C$. angelini Westergård, 1950, and probably Paradoxides. Westergård (1950) recognised that two species of Centropleura were present in Angelin's collections and referred some specimens to his new species $C$. angelini. The only specimen from Angelin's material that was figured by Westergård (1950, pl. 1, fig. 1) and identified as C. loveni (RM Ar. 32354) is here selected as the lectotype. It is a small, fragmentary cranidium.

New material. Numerous disarticulated sclerites and 
three articulated axial shields in GGU 301311-301313 and 313115.

Emended diagnosis. Cranidium about 1.4 times wider than long. Exsagittal parts of anterior border with slight inward deflections in large holaspides; deflection lacking in small holaspides. Anterior border furrow deep and narrow anteriorly, shallowing and widening laterally. Axial furrow deep and narrow anteriorly, shallowing and widening posteriorly. Glabella pyriform, elevated well above fixigenae, reaching greatest width at $\mathrm{L} 4$, reaching greatest height in center of L5, sloping steeply forward to anterior border furrow and gently backward to occipital furrow. Lateral glabellar furrows shallowing anteriorly; S1 confluent, composite; S2 nearly straight, slightly oblique backward; S3 slightly convex, transverse; S4 slightly convex. Occipital furrow deep at sides, shallowing medially. Occipital ring lacking node. Fixigena with small metafixigenal spine near posterolateral end of border. Posterior margin and posterior border furrow strongly deflected on axial side of spine. Palpebral lobe not extending to posterior border furrow. Genal bar slightly bowed laterally.

Labrum slightly wider than long, moderately convex; having nearly straight, tapering lateral margin. Posterior wing long, truncated, slightly deflected in middle.

Thorax narrowest at segment 9, axis slightly tapering posteriorly. Anterior segments ( 1 to 13 ) having pleural spines that successively increase in length toward posterior. Segments 14 to 16 having curved anterior and posterior margins; pleural tips extending beyond pygidium, extension decreasing posteriorly from segment 14 .

Pygidium bell-shaped, width about 1.5 times length. Anterior margin slightly curved; anterolateral corner broadly rounded; lateral margin slightly curved, diverging posteriorly. Axis having 2 or 3 rings and terminal piece, moderate to strongly tapered posteriorly. Posterior margin having 3 pairs of spines, length decreasing adaxially; spine pairs 1 and 2 posteromedially directed; spine pair 3 very short, posteriorly directed. Pleural furrows consisting of 3 shallow, wide pairs, weakening posteriorly.

Terrace lines cover dorsal surface except palpebral lobe, palpebral area of fixigena, anterior border furrow of cranidium, and axial furrows; strong except on glabella and anterior margin of axial rings away from middle. Terrace lines also present ventrally on marginal areas and labrum.

Remarks. Well-preserved, but somewhat crushed, specimens referable to $C$. loveni are present in the lower Kap Stanton Formation of North Greenland. Except for differences attributable to crushing, these specimens are identi- cal to inflated specimens from Sweden and Denmark, some of which are introduced here for comparison (Figs 19.11, 20.3).

Angelin (1851) included representatives of two species of Centropleura in his concept of $C$. loveni from the Andrarum Limestone of Scania, Sweden (Westergård, 1950). Characters that can be used to differentiate the two species are primarily in the cranidium. The name $C$. loveni has been restricted to cranidia that have palpebral lobes not extending to the posterior border furrow, and that have the posterior margin and border furrow forwardly bent near the posterolateral corner (Westergård, 1950). Cranidia that have the palpebral lobes extending to the border furrow, a nearly straight posterior margin, and a nearly straight border furrow, belong to $C$. angelini.

Morphologically different pygidia also have been found in the Andrarum Limestone. One morph tends to have an elliptical outline (Fig. 20.7; Westergård, 1950, pl. 1, fig. 4) and another tends to have a bell-shaped outline (Fig. 20.3, Westergård, 1950, pl. 1, fig. 10a). As no complete specimens of either species were known at the time of Westergård's writing, the pygidia could not be assigned with certainty to their proper cranidia. Complete, articulated specimens of $C$. loveni from North Greenland (Fig. 18) show that Westergård incorrectly assigned elliptically shaped pygidia to C. loveni. By implication, he also incorrectly assigned bell-shaped pygidia to $C$. angelini.

Whether or not the rostral plate of C. loveni was fused to the labrum is uncertain. A disarticulated rostral plate from North Greenland (Fig. 20.2) seems to have been cleanly separated from the labrum medially, but fragments of exoskeleton appear to adhere to the distal margins. Illustrated labra of Centropleura that are free of the dorsal exoskeleton (Westergård, 1950, pl. 2, figs 2, 3; herein, Fig. 20.5) are also free of the rostral plate, suggesting that the labrum and rostral plate were either unfused or weakly ankylosed.

Ontogeny and heterochrony. New material of C. loveni from North Greenland and Scandinavia (Figs 18, 19, $20.1,20.3,20.4$ ) provides substantially more information about the ontogeny of this species than has been previously known. Small cranidia (Figs 19.1-19.7) show a remarkable resemblance in overall morphology to meraspides or small holaspides of Xystridura templetonensis (compare with specimens figured by Öpik, 1975). This supports monophyly in the paradoxidids and furthermore suggests that major morphological innovations in the cranidium of Centropleura arose through paedomorphosis from the common ancestor of the two major paradoxidid clades. Critical points of comparison are (1) the facial sutures, which are deeply incised in meraspides of 


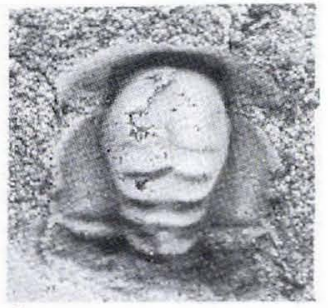

1

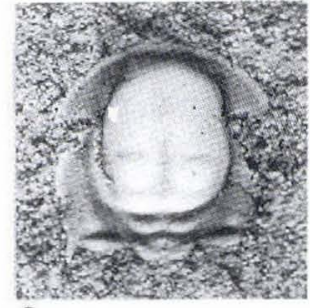

2
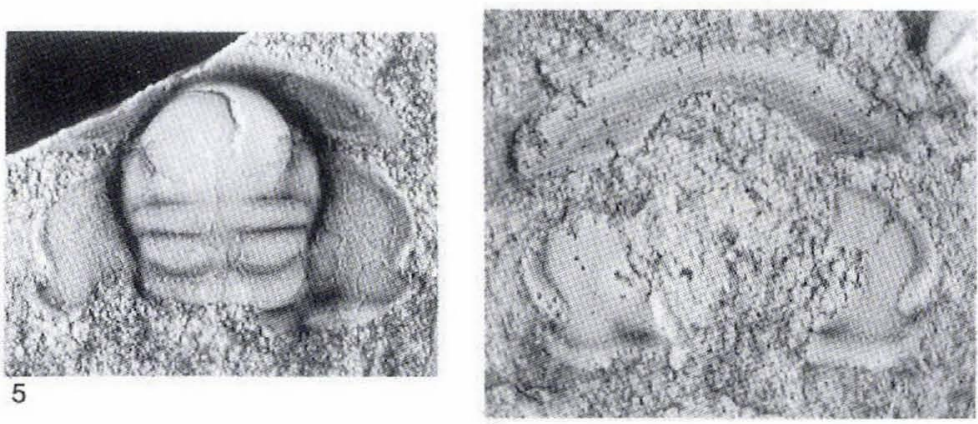

6
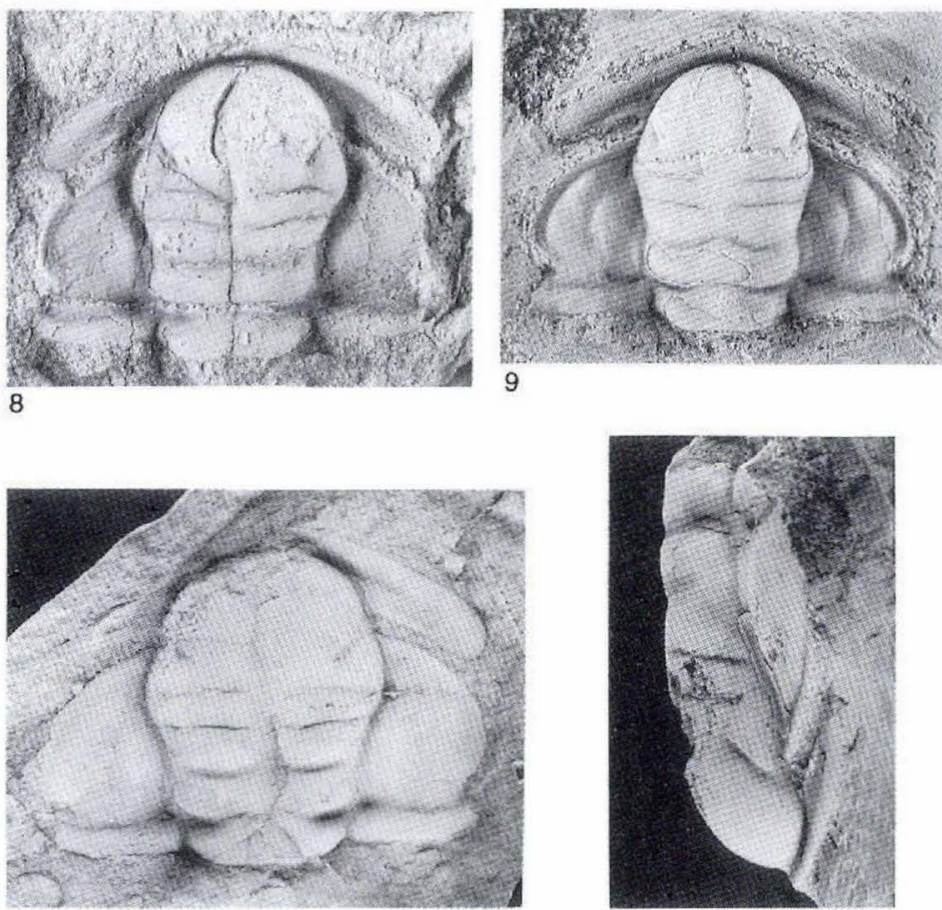

10

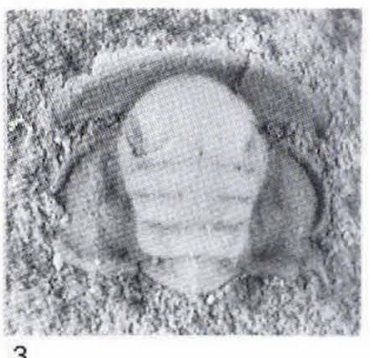

W.17.

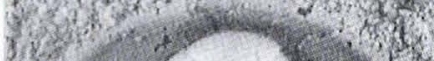

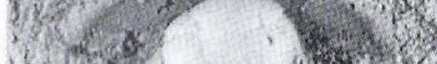
1. ifis:

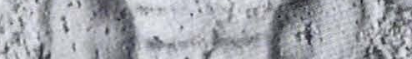

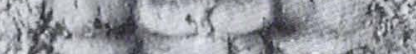

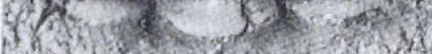

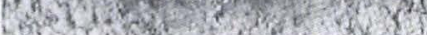
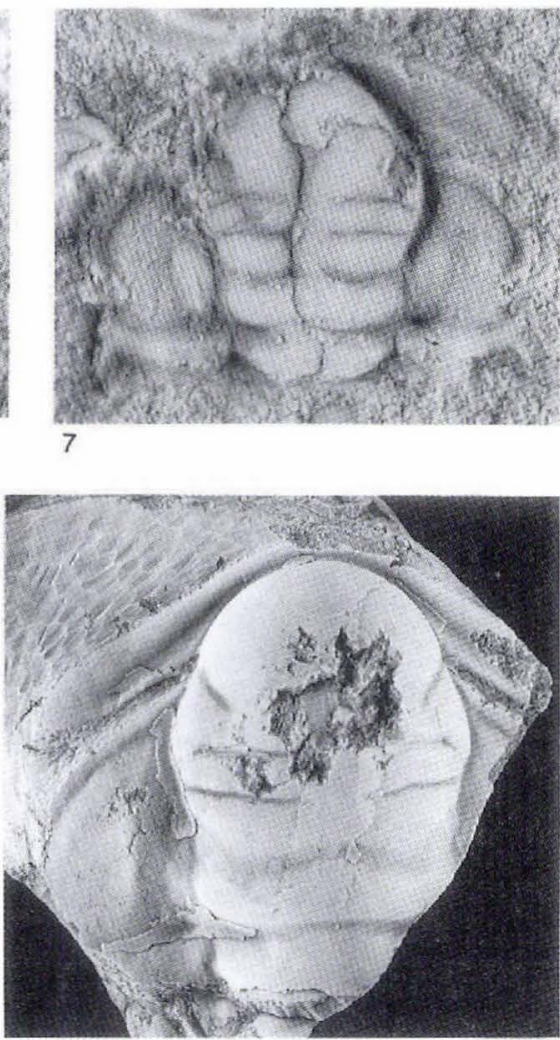

$11 \mathrm{a}$

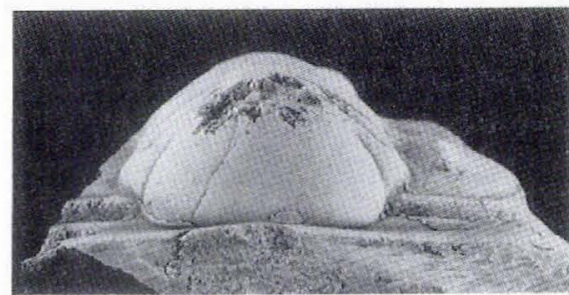

$11 \mathrm{c}$

Fig. 19. Centropleura loveni (Angelin). All specimens from GGU 301313, unless otherwise stated.

1-5, small cranidia, MGUH 21.274-21.278, respectively, all x 10. 6, small, damaged cranidium, MGUH 21.279, × 8. 7, small, crushed cranidium, MGUH 21.280, × 8. 8, cranidium, MGUH 21.281, × 3. 9, medium-sized cranidium from the Andrarum Limestone of Andrarum, Scania, Sweden; introduced for comparison; USNM 465519, $\times 3$. 10, cranidium, MGUH 21.282, $\times 1.5 .11$, large, exfoliated cranidium in dorsal (a), left-lateral (b), and frontal views from the Andrarum Limestone of Andrarum, Scania, Sweden; introduced for comparison; USNM 465520, $\times 1$. 
Fig. 20. Specimens of Centropleura.

1-6, Centropleura loveni (Angelin). 1, pygidium, mostly exfoliated, MGUH 21.283 from GGU $313115, \times 2$. 2, weathered rostral plate, MGUH 21.284 from GGU $313115, \times 1.3$, pygidium, from Borregård, Bornholm, Denmark; introduced for comparison; USNM 465521, $\times 2.5$. 4, smallest observed pygidium, MGUH 21.285 from GGU 301313, × 12 , 5, labrum, MGUH 21.286 from GGU 313115, × 2. 6, incomplete librigena retaining much of the genal spine, preserved mostly as an external mould, MGUH 21.287 from GGU 301313, × 1 .

7, Centropleura angelini Westergård; incomplete pygidium from the Andrarum Limestone, Andrarum, Scania, Sweden; introduced for comparison; USNM 465522, $\times 2$.

8, Centropleura angelini? Westcrgård; pygidium, mostly exfoliated, MGUH 21.288 from GGU $301313, \times 2.5$.
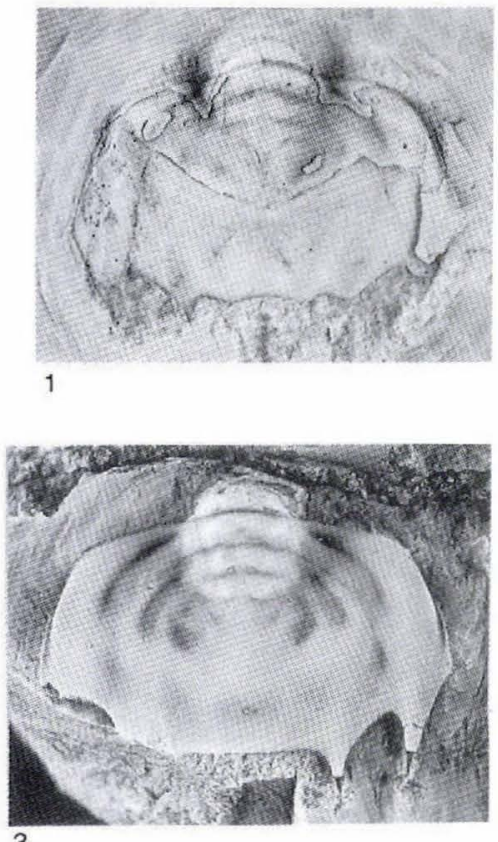

3

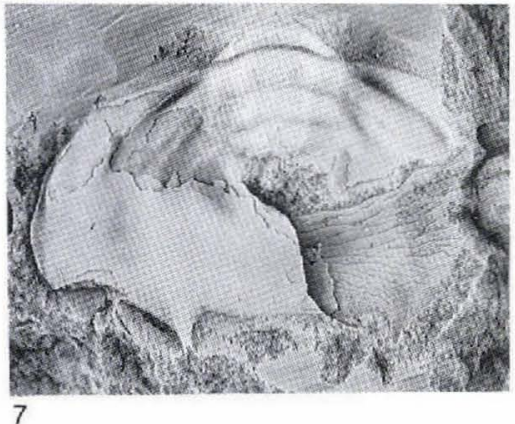

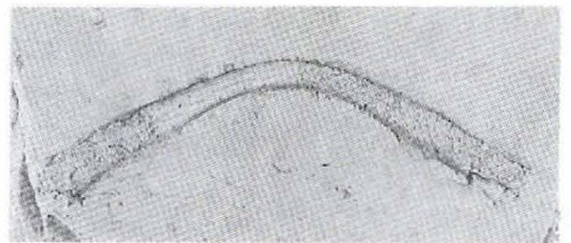

2
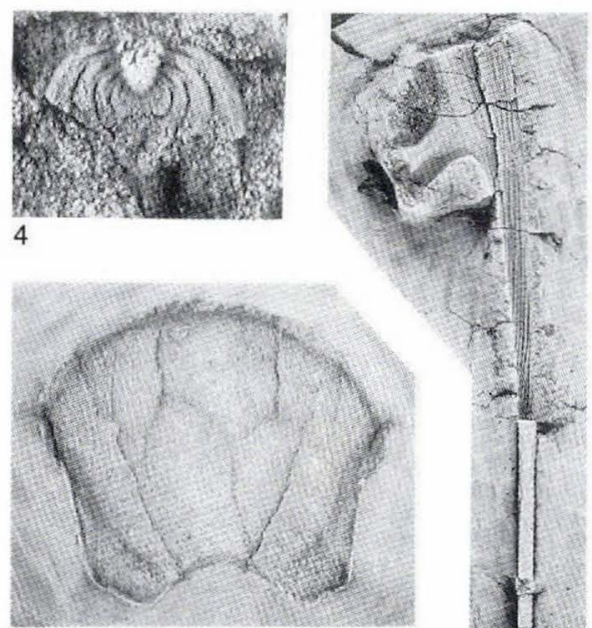

5

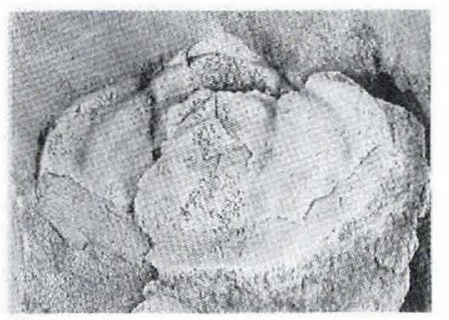

8 both genera and become retrodivergent in holaspides of Centropleura; (2) the genal bars, which are lost in holaspides of Xystridura but not Centropleura; and (3) the metafixigenal spines, which are lost early in meraspid ontogeny by Xystridura but are retained by holaspides of Centropleura. Both genera evidently underwent protraction and retraction (see McNamara, 1986b) of the anterior glabella during the late meraspid or holaspid period, but $C$. loveni seems to have undergone more than $X$. templetonensis.

As discussed in remarks on the Paradoxididae, Centropleura has characters in the post-cephalic area that suggest a peramorphic origin.

Occurrence. Disarticulated sclerites and articulated axial shields are moderately common in mudstone beds of the basal Kap Stanton Formation at locality 3, Peary Land. Besides North Greenland, C. loveni has been reported from Sweden, Denmark, and Bennett Island. Its observed range is confined to the informal lower part of the Lejopyge laevigata Zone of Robison (1984).

\section{Centropleura angelini? Westergård, 1950 Fig. 20.8}

Centropleura loveni Angelin. Angelin (in part), 1854, p. 87; Angelin (in part), 1878, p. 95, pl. 3, figs 1, 1a; Westergård (in part), 1950, pp. 4, 5, pl. 1, fig. 4; pl. 2, figs 1, 3?; Poulsen (in part) in Harrington et al., 1959b, p. O214, fig. 154b; Reyment (in part), 1980, figs 15a?, 15b

Centropleura angelini Westergård (in part), 1950, p. 6, pl. 1, figs 5-9 (not 10)

Holotype. Cranidium, RM Ar. 1617.

Material. One pygidium in GGU 301313. 
Remarks. A single, mostly exfoliated pygidium of Centropleura in GGU 301313 seems to fall within the range of variation of $C$. angelini as herein revised (see remarks under $C$. loveni). The pygidium is much wider than long and has a roughly elliptical outline. A specimen referred to $C$. angelini from the Andrarum Limestone of Sweden is illustrated for comparison (Fig. 20.7). The identification of the specimen from North Greenland is questionable because a cranidium referable to $C$. angelini was not found in any collection from North Greenland, and because examination of pygidia referable to $C$. loveni from Scandinavia and North Greenland has shown considerable variation in outline of the pygidium.

Occurrence. Present in mudstone beds of the basal Kap Stanton Formation at locality 3, Peary Land. Besides North Greenland, C. angelini is also known from Scandinavia. Specimens definitely referable to $C$. angelini are from the informal lower part of the Lejopyge laevigata Zone of Robison (1984).

\section{Family Solenopleuridae Angelin Genus Parasolenopleura Westergård, 1953}

Liostracus Angelin (in part), 1854, p. 27; Angelin (in part), 1878 , p. 27

Parasolenopleura Westergård, 1953, pp. 21, 22; Poulsen in Harrington et al., 1959b, p. O275; Rushton, 1966, pp. 46, 47

Type species. Calymene aculeata Angelin, 1851, pp. 23, 24 (not Poletaeva, 1955), by original designation (Westergård, 1953, p. 21).

Remarks. The generic concept of Westergård (1953, pp. $21,22)$ is followed here.

\section{Parasolenopleura aculeata (Angelin, 1851)} Fig. 21

Calymene aculeata Angelin, 1851, p. 23, pl. 19, fig. 2; Angelin, 1878 , p. 23 , pl. 19 , fig. 2

Liostracus aculeatus (Angelin). Angelin, 1854, p. 27; Angelin, 1878, p. 27, pl. 19, fig. 2; Linnarsson, 1879, p. 11, pl. 1, figs 12-15; Linnarsson, 1883 , p. 22 ; Walcott, 1884 , pl. 6, fig. 6; Lesley, 1889, p. 351, fig.; Walcott, 1913, p. 137, pl. 13, fig. 6; Krashopeeva, 1958, p. 109; Strand, 1929, p. 351, pl. 2, fig. 5; ?Brøgger, 1878 , p. 46 (30), pl. 3 , fig. 3 (cf. Parasolenopleura spinigera Westergård, fide Westergård, 1953, p. 23)

Andrarina aculeatus (Angelin). Raymond, 1937, p. 1106

Parasolenopleura aculeata (Angelin). Westergărd, 1953, pp. 23-25, pl. 5, figs 6-10, pl. 6, figs 1-4; Poulsen in Harrington et al., 1959b, p. O275, fig. 204,12

Parasolenopleura ef. aculeata (Angelin). Rushton, 1966, p. 47, pl. 6, fig. 14; Morris, 1988, p. 168

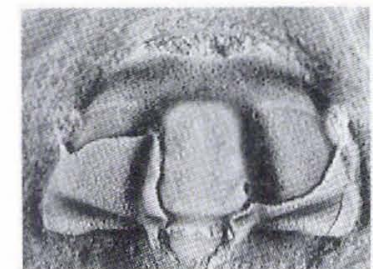

Fig. 21. Parasolenopleura aculeata (Angelin); partly exfoliated cranidium, MGUH 21.289 from GGU 298969, × 7 .

Lectotype. Cranidium, RM Ar. 46143a.

New material. One cranidium in GGU 298969.

Remarks. The species concept of Westergard (1953, pp. $23,24)$ is followed here. The new specimen from Nyeboe Land (Fig. 21) is a mostly exfoliated cranidium with a broken anterior border and occipital ring. It agrees in all characters with specimens figured by Westergård (1953) and, although slightly younger than that material, does not add new morphological information about the species.

Westergård (1953, p. 24) noted that the surface granulation in this species is a variable character. The new specimen from North Greenland has fine, densely spaced granules similar to specimens illustrated (Westergård, 1953, pl. 6, figs 3, 4) from the Exsulans Limestone of Scania, Sweden.

Occurrence. Present in mudstone of the upper part of the Henson Gletscher Formation at locality 1, Nyeboe Land. Specimens examined by Angelin (1851) are from the Acrothele (Redlichella) granulata conglomerate of Borgholm, Sweden. Those specimens and the ones reported by Westergård (1953) from Sweden and Norway are from the Ptychagnostus gibbus Interval-zone. A specimen compared with this species by Rushton (1966) was found in a loose block that may have come from the Purley shales. The Purley shales of England contain a fauna indicative of the $P$. gibbus Interval-zone. The new specimen from North Greenland extends the range of this species up to the $P$. atavus Interval-zone.

\section{Genus Solenopleura Angelin, 1854}

Solenopleura Angelin, 1854, p. 26; Salter, 1866, p. 305; AngeIin, 1878, p. 26; Salter, 1881, p. 499; Walcott, 1884, p. 36; Matthew, 1887, p. 357; Miller, 1889, p. 567; Beecher, 1895 , p. 178; Pompeckj, 1896, p. 546; Beecher, 1897, p. 192; Lindström, 1901, p. 25; Grabau \& Shimer, 1910, p. 277; Vogdes, 1925, p. 113; Lake, 1931, p. 133; Kobayashi, 1935, p. 262; Howell, 1937, p. 1173; Lermontova, 1940, p. 151; Ivshin, 1953, p. 93; Chernysheva, 1953, p. 34; Westergård, 
1953, pp. 7-11; Hupé, 1955, p. 137; Poulsen in Harrington et al., 1959b, p. O275; Egorova et al., 1960, pp. 231, 232; Ivshin et al. in Chernysheva, 1960, p. 119; Chernysheva, 1961, p. 242; Palmer \& Gatehouse, 1972, p. D25; Chernysheva, 1980, pp. 65-67, 72, 73

Calymene Brongniart (in part). Angelin, 1878, pp. 22, 23

Jincella Šnajdr, 1957, p. 244; Šnajdr, 1958, p. 196

Type species. Calymene holometopa Angelin, 1851, p. 23 , by subsequent designation (Walcott, 1884, p. 36).

Remarks. The generic concept of Solenopleura and arguments relating to its type species were discussed by Chernysheva (1980). Her diagnosis of the genus is followed here.

\section{Solenopleura bucculenta Grönwall, 1902} Fig. 22

Solenopleura bucculenta Grönwall, 1902, pp. 152, 153, pl. 4 , fig. 18; Czarnocki, 1927, p. 196; Westergård, 1953, pp. 13, 14, pl. 3, figs $1-3$

Solenopleura cf. bucculenta Grönwall. Cobbold in Cobbold \& Pocock, 1934, p. 366 , pl. 42, fig. 18a, b; Morris, 1988, p. 212

Holotype. Repository unknown.

New material. Numerous disarticulated sclerites and articulated exoskeletons in GGU 301313 and 313115.

Remarks. Until now, S. bucculenta has been known from only cranidia, which were thoroughly described by Westergård (1953, pp. 13, 14). For comparison with new material from North Greenland, two specimens from Scandinavia are illustrated here (Figs 22.7, 22.9).

Specimens from North Greenland add new information about sclerites other than the cranidium. The librigena (Fig. 22.5) is narrow, moderately convex, and has a semicircular outline. Its border is wide and convex and the border furrow is deep and wide. An incipient spine is
Fig. 22. Solenopleura bucculenta Grönwall. All specimens from GGU 301313, unless otherwise stated.

1, small cranidium, MGUH $21.290, \times 16.2$, incomplete pygidium, mostly exfoliated, MGUH $21.291, \times 3.3$, partly exfoliated cranidium in dorsal (a), frontal (b), and right-lateral (c) views, MGUH $21.292, \times 3.4$, incomplete labrum, MGUH 21.293, × 3 . 5 , incomplete librigena, MGUH $21.294, \times 3.6$, partly exfoliated cranidium in dorsal (a) and leftlateral (b) views, MGUH 21.295. $\times 3.7$, exfoliated cranidium from the Andrarum Limestone of Andrarum, Scania, Sweden; introduced for comparison; USNM $465523, \times 3.8$, weathered axial shield, MGUH 21.296 from GGU $313115, \times 1.5$. 9, large cranidium, incomplete and exfoliated, from Øleă, Bornholm, Denmark; introduced for comparison; USNM $465524, \times 1.25$.
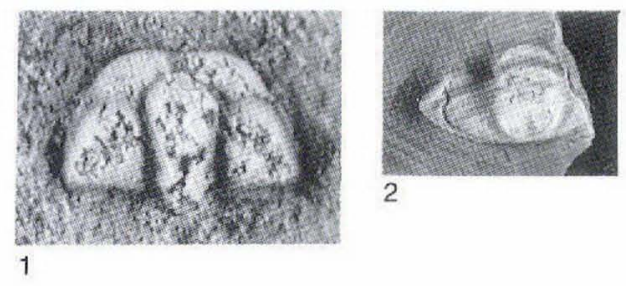

2
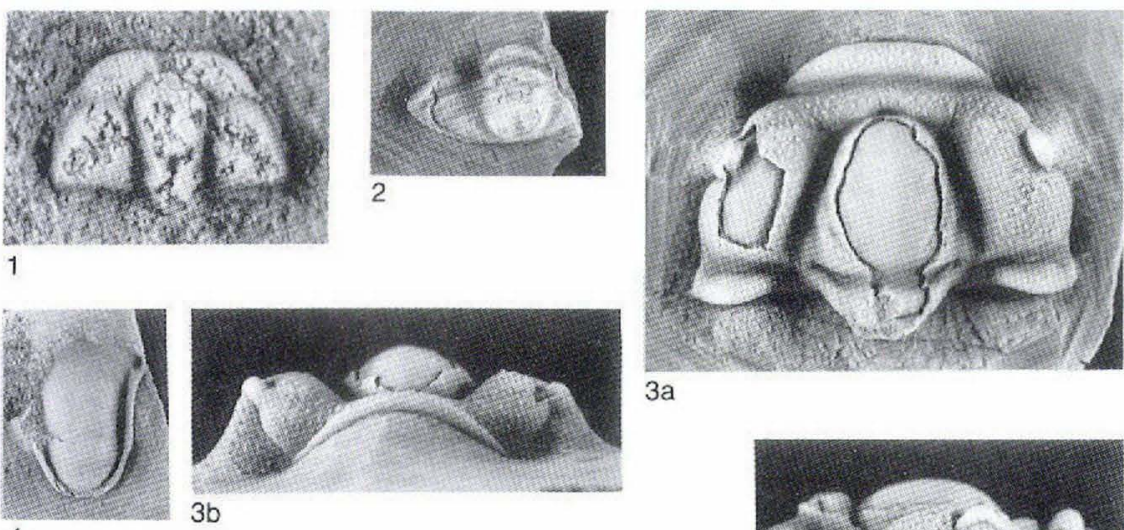

3a

4

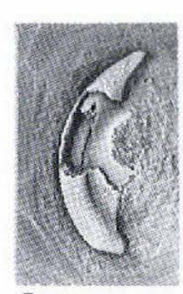

5

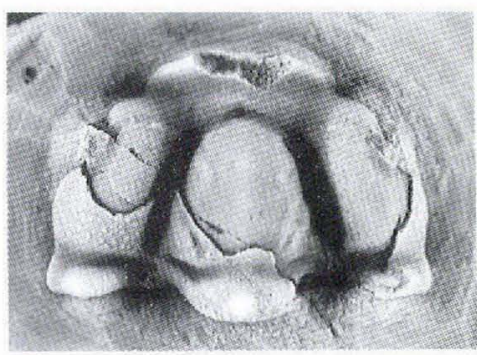

$6 a$

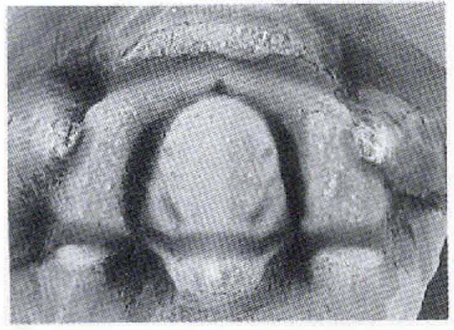

7

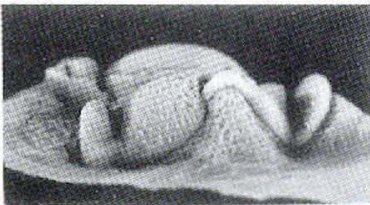

3c

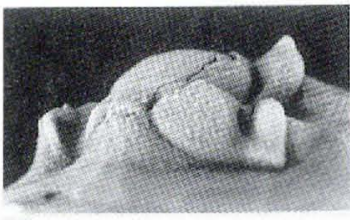

$6 b$

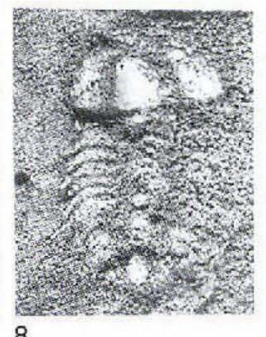

8

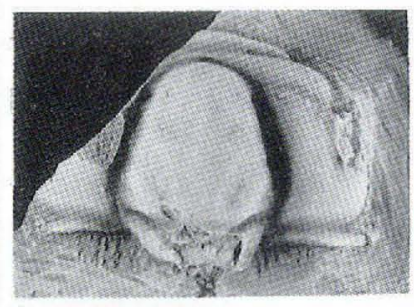

9 
present at the genal angle. Surface prosopon consists of rather widely spaced, large granules between which are smaller, densely spaced granules. Granules are absent in the border furrow.

The labrum is known from a single broken specimen (Fig. 22.4). It is long, relatively narrow, and convex. The border is convex and separated from the central body by a deep and narrow furrow. The anterolateral corners are not preserved.

Several axial shields are in collection 313115 but, because of weathering, few details are preserved. At least ten segments are in the thorax, and most appear to have falcate tips (Fig. 22.8).

The best available pygidium (Fig. 22.2) is mostly exfoliated. It is moderately convex, and has a width that is about twice the length. The axis is strongly convex, and contains two rings and a long terminal piece that extends almost to the posterior margin. A weak medial groove extends the entire length of the terminal piece in the steinkern. The axis is widest at the second ring, and tapers slightly both anteriorly and posteriorly. Two distinct ridges and two weak interpleural furrows are in the pleural lobes. A border is not present. Test adheres to the internal mould only near the anterolateral corner, showing surface prosopon of small, densely spaced granules. Large granules like those on the cephalon are evidently absent from the pygidium.

Occurrence. Common in mudstone beds of the basal Kap Stanton Formation at locality 3, Peary Land. The species seems to range from the Ptychagnostus punctuosus Zone to the Lejopyge laevigata Zone of Robison (1984). Specimens described by Westergård (1953) from Sweden and Denmark are from the Paradoxides davidis Zone and the lower part of the Lejopyge laevigata Interval-zone. Specimens compared with this species (Cobbold in Cobbold \& Pocock, 1934, p. 366) from Rushton, Shropshire, England, are from the Paradoxides forchhammeri Zone, which probably corresponds to about the same interval ( $P$. punctuosus Zone to lower L. laevigata Zone).

\section{Genus Solenopleurella Poulsen, 1927}

Solenopleurella Poulsen, 1927, p. 269; Shimer \& Shrock, 1944. p. 617; Lermontova, 1951, pp. 132-133; Rasetti, 1951, pp. 240, 241; Poulsen in Harrington et al., 1959b, p. O275; Egorova et al., 1960, p. 232; Ivshin et al. in Chernysheva, 1960, p. 119 ; Rasetti, 1965 , p. 1013

Type species. Solenopleurella ulrichi Poulsen, 1927, by original designation (Poulsen, 1927, p. 269).
Remarks. The generic concept of Poulsen (in Harrington et al., 1959b, p. O275) is followed here.

\section{Solenopleurella transversa? Rasetti, 1965} Fig. 23

Solenopleurella transversa Rasetti, 1965, p. 1014, pl. 120, figs 22,23

\section{Holotype. Cranidium, USNM 145034.}

New material. One cranidium in GGU 319790.

Remarks. This species was described (Rasetti, 1965) on the basis of a single broken cranidium from central Pennsylvania. A cranidium from Nyeboe Land is questionably assigned to this species because it agrees with the holotype in all critical characters. Aside from a difference in size, the new specimen (Fig. 23) differs from the holotype by having a slightly shorter palpebral lobe, and differences in surface granulation. The holotype has very low granules that are fine and closely spaced on the anterior border, moderately spaced on the occipital ring, and coarse and moderately spaced on the palpebral area of the fixigena. The specimen from North Greenland has granules of bimodal size on the fixigena. Such characters are variable within species of other solenopleurid trilobites and are here given no taxonomic significance.

The Greenland specimen shows two well-impressed pairs of lateral glabellar furrows and a third pair that is faintly impressed. Although Rasetti (1965) reported only two pairs of furrows, re-examination of the holotype

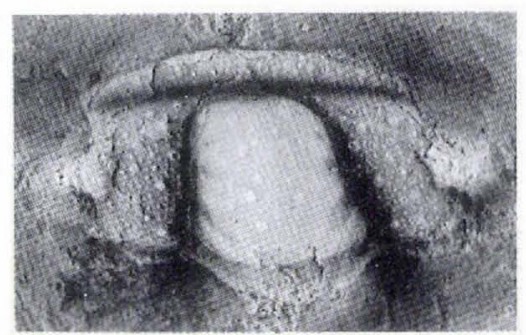

$1 \mathrm{a}$

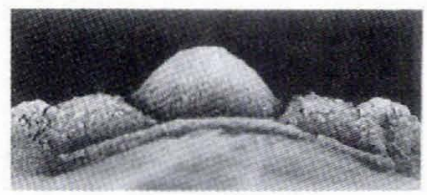

$1 b$

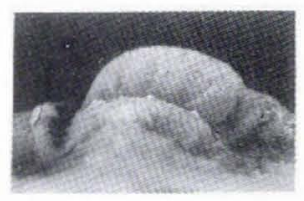

$1 \mathrm{c}$
Fig. 23. Solenopleurella transversa? Rasetti.

1, partly exfoliated cranidium in dorsal (a), frontal (b), and left-lateral (c) views, MGUH 21.297 from GGU 319790, × 8 . 
(USNM 145034) reveals the presence of a third pair that is very faintly impressed.

Occurrence. Present in a packstone bed of the basal Kap Stanton Formation at locality 2, Nyeboe Land. It is associated with trilobites indicative of the Ptychagnostus atavus Zone of Robison (1984). The holotype is from the Pleasant Hill Limestone (upper Middle Cambrian) of Henrietta, Blair County, Pennsylvania (Rasetti, 1965).

\section{Family Zacanthoididae Swinnerton Genus Zacanthoides Walcott, 1888}

Embolimus Rominger, 1887, p. 15; Woodward, 1902, p. 539 Zacanthoides Walcott, 1888, p. 165; Miller, 1889, p. 569; Beecher, 1897, p. 191; Matthew, 1897, p. 187; Matthew, 1899, p. 63; Lindström, 1901, p. 16; Grönwall, 1902, p. 129; Grabau \& Shimer, 1910, p. 273; Kobayashi, 1935, p. 123; Shimer \& Shrock, 1944, p. 619; Palmer, 1954, pp. 69, 70; Rasetti in Harrington et al., 1959b, p. O227: Suvorova \& Pokrovskaia in Chernysheva, 1960, p. 77; Palmer, 1968, p. B50; Palmer \& Halley, 1979, pp. 96, 97; Young \& Ludvigsen, 1989, pp. 20, 21

Type species. Embolimus spinosa Rominger, 1887, p. 15 (= Zacanthoides romingeri Resser, 1942, pp. 56, 57).

Remarks. The generic diagnosis of Palmer (1954, p. 69) is followed here.

\section{Zacanthoides sp.}

Fig. 24

Material. Six cranidia and three pygidia in GGU 298970.

Remarks. Broken cranidia and pygidia in GGU 298970 belong to a distinctive species of Zacanthoides. The cranidium is subtrapezoidal in outline, gently convex, and the anterior margin is slightly curved. It has a low, long glabella that expands slightly forward and is bluntly rounded anteriorly. The axial furrow is weak. Three pairs of large muscle scars are present on the glabella; S1 is long and oblique backwards, S2 is short and transverse, and S3 is oblique forwards. The occipital furrow is shallow, but deepest at the sides. A small median node is present on the occipital ring. The frontal area is approximately one-tenth the total length of the cranidium. The fixigena is flat, and its width is subequal with that of the occipital ring. The palpebral area is long, extending to the anterior end of the occipital ring. The anterior end of the palpebral lobe is continuous with the eye ridge. A welldefined palpebral furrow is present. The course of the anterior section of the facial suture is strongly divergent forward from the palpebral lobe. The posterior limb is not preserved in any specimen. The surface is smooth.

The pygidium, exclusive of the border spines, is semielliptical in outline. Its sagittal length is about 0.6 times the width. The axis is convex, and slightly tapered posteriorly. It contains four rings and a long terminal piece. The pleural field is convex, subtriangular, and slightly narrower than the axis. Three pleural furrows are present; the anterior two are distinct and the third is weak. The border is poorly defined, flat, and narrower than the pleural field. Four pairs of marginal spines are present, the anterior two being long, and the posterior two being short. The surface is smooth.

Although seemingly distinctive, the new material of Zacanthoides is not assigned to a species because it is not well preserved. It is most similar to $Z$. variacantha Palmer \& Halley (1979, p. 97) from the western United States in overall appearance. It differs from that species, however, primarily in having a straighter anterior cranidial border, in lacking a cranidial plectrum, and in having two pairs of elongated marginal pygidial spines instead of one pair.

Occurrence. Present in a packstone bed from approximately $56 \mathrm{~m}$ above the base of the Henson Gletscher Formation at locality 1, Nyeboe Land. It is associated with trilobites indicative of the Ptychagnostus gibbus Interval-zone of Robison (1984).

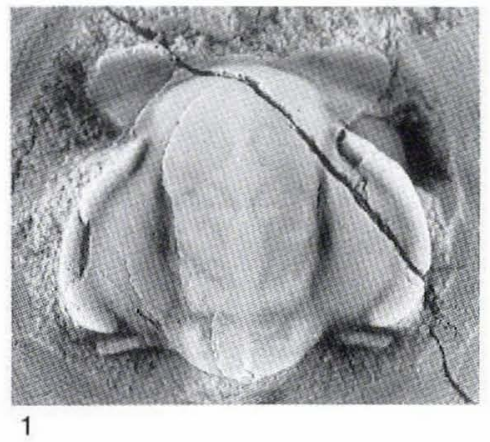

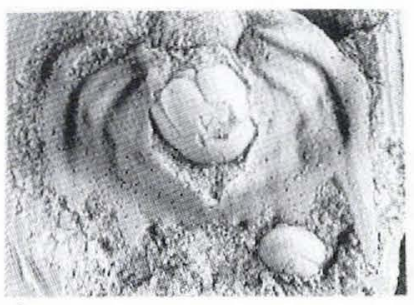

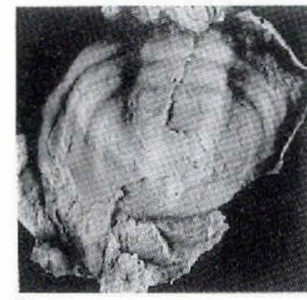

3
Fig. 24. Zacanthoides sp. All specimens from GGU 298970. 1, incomplete cranidium, MGUH 21.298, × 5. 2, incomplete, exfoliated pygidium, MGUH 21.299, $\times 4$. 3, latex cast of incomplete pygidium, MGUH $21.300, \times 2$. 
Family unassigned

\section{Genus Elrathia Walcott, 1924}

Elrathia Walcott, 1924, p. 56; Robison, 1964, pp. 540, 541 (see for synonymy to 1964); Robison, 1988, p. 92

Type species. Conocoryphe (Conocephalites) kingii Meek (1870, p. 63).

Remarks. The generic diagnosis of Robison (1964) is followed here.

\section{Elrathia sp.}

Fig. 25

Material. Several small cranidia and two pygidia in GGU 298970.

Remarks. Several incomplete cranidia and two exfoliated pygidia of a species of Elrathia are present in GGU 298970. They are not assigned to species because the material is not well preserved. The cranidium is characterised by having a moderately upturned anterior border, a moderately wide axis, three incipient lateral glabellar furrows, slightly convergent sides of the glabella, a weak medial node on the occipital ring, palpebral lobes that are about one-third the length of the glabella, and moderately strong eye ridges. Fine granules cover the entire cranidium except in the furrows, and faint type 4 caeca radiate from the anterior and anterolateral areas of the axial furrow into the preglabellar field. The pygidium is alate with weak posterolateral swellings. The axis is moderately convex and slightly tapered. It contains four rings, a
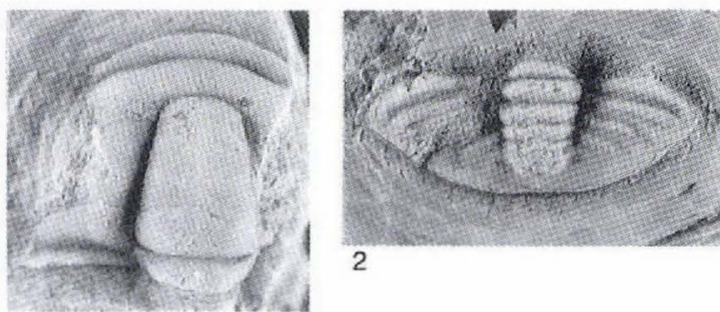

2

$1 \mathrm{a}$
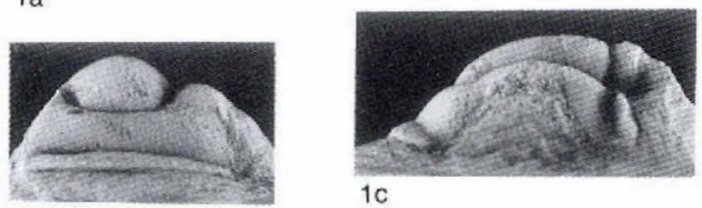

$1 \mathrm{~b}$

Fig. 25. Elrathia sp., both from GGU 298970.

1, small, broken cranidium in dorsal (a), frontal (b), and leftlateral (c) views, MGUH 21.301, × 6. 2, exfoliated pygidium, MGUH $21.302, \times 2$. terminal piece, and a short postaxial ridge. Three pairs of strong furrows are in the pleural lobes.

Occurrence. Sclerites are present in wackestone beds approximately $56 \mathrm{~m}$ above the base of the Henson Gletscher Formation at locality 1, Nyeboe Land. They are associated with trilobites indicative of the Ptychagnostus gibbus Interval-zone of Robison (1984).

\section{Genus Syspacephalus Resser, 1936}

Syspacephalus Resser, 1936, p. 28; Lochman, 1947, pp. 62-65; Rasetti, 1951, pp. 241, 242; Rasetti, 1955, p. 6; Rasetti in Harrington et al., 1959b, p. O237; Suvorova in Chernysheva, 1960, p. 117; Shaw, 1962, p. 337; Fritz, 1972, p. 47; Robison, 1976, p. 102; Palmer \& Halley, 1979, p. 115

Elrathina Resser, 1937b, p. 11; Diess, 1939, pp. 87, 88; Shimer \& Shrock, 1944, p. 611; Rasetti, 1951, p. 221; Howell in Harrington et al., 1959b, p. O240; Balashova et al. in Chernysheva, 1960, p. 105; Zhuravleva et al., 1970, p. 37; Palmer \& Halley, 1979, p. 103; Young \& Ludvigsen, 1989, p. 24

Type species. Agraulos charops Walcott, 1917, p. 72, by original designation (Resser, 1936, p. 28).

Remarks. Based on the examination of a large number of specimens at the University of Kansas and in the U.S. National Museum, I agree with the conclusion that Syspacephalus and Elrathina represent a single lineage of trilobites (Robison, 1976, p. 102). Representatives of this ptychopariid lineage show considerable morphological variation in the cranidium, and, although individual species may appear distinct, evaluation of all species assigned to both genera indicates that there are no consistent and meaningful differences between Syspacephalus and Elrathina.

\section{Syspacephalus sp. 1}

Figs $26.1-4$

Material. Six cranidia and three librigenae in GGU 298969.

Remarks. Isolated cranidia in GGU 298969 represent a species of Syspacephalus that has a narrow glabella, long and shallow lateral glabellar furrows, a convergent and convex anterior branch of the facial suture, and a weak eye ridge. Associated librigenae are characterised by being narrow and having a long genal spine.

Occurrence. Disarticulated sclerites are present in a packstone bed from approximately $71 \mathrm{~m}$ above the base of the Henson Gletscher Formation at locality 1, Nyeboe Land. The specimens are from the $P$. atavus Interval-zone. 
Syspacephalus sp. 2

Figs 26.5, 6; 31.4a

Material. Numerous cranidia in GGU 298970.

Remarks. This species of Syspacephalus is characterised by a moderately long, smooth cranidium. The glabella is almost parallel-sided, narrow, slightly rounded anteriorly, and slightly but distinctly notched at the fossula, especially in small holaspides. The lateral furrows are deep in small holaspides, and shallow to moderately deep in large holaspides; S1 are geniculate, S2 are straight and weakly oblique backward, and S3 are transverse with a distinct anteromedial depression. The occipital furrow is deep

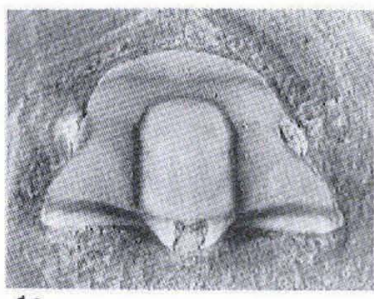

1a

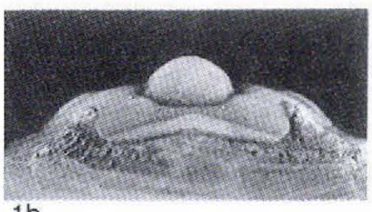

$1 b$

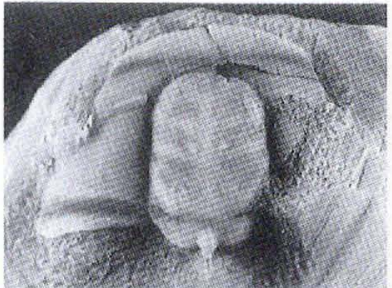

$6 a$

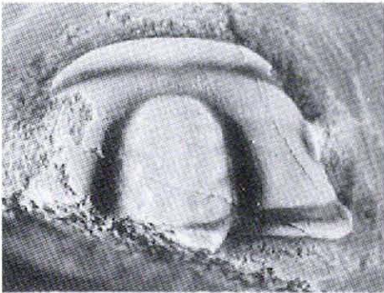

$8 a$

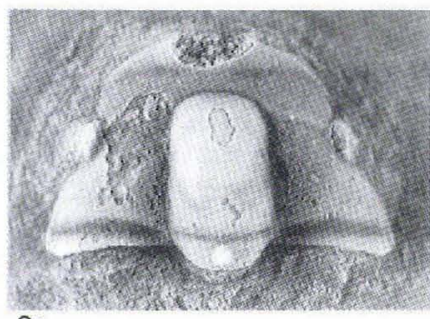

$2 a$

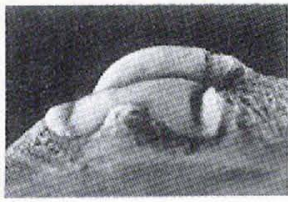

$1 c$

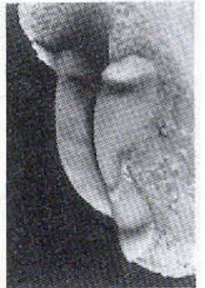

$6 b$

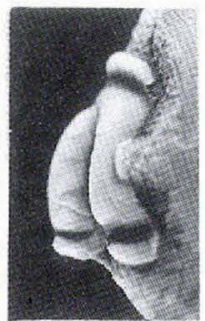

$8 b$

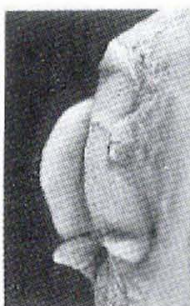

$2 b$

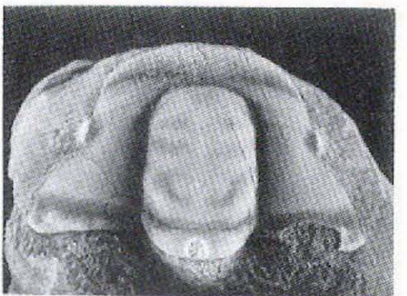

$5 a$

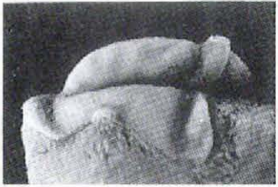

$5 b$

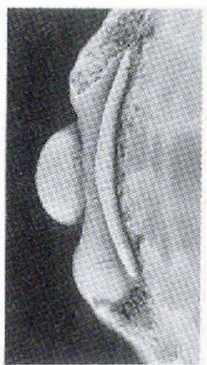

$8 \mathrm{c}$

$9 a$
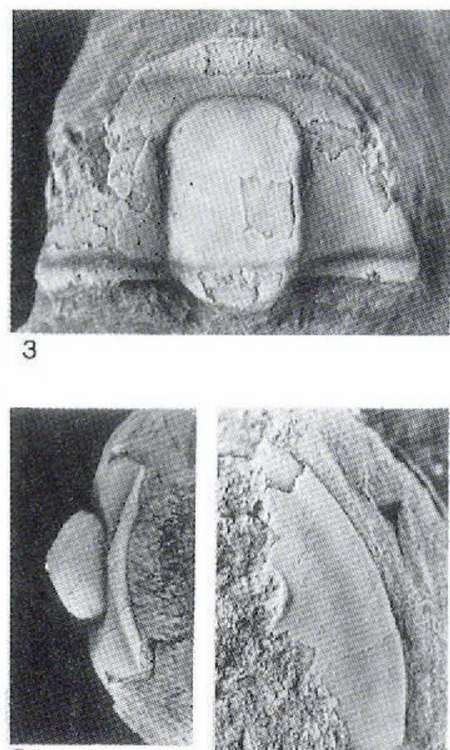

$5 c$
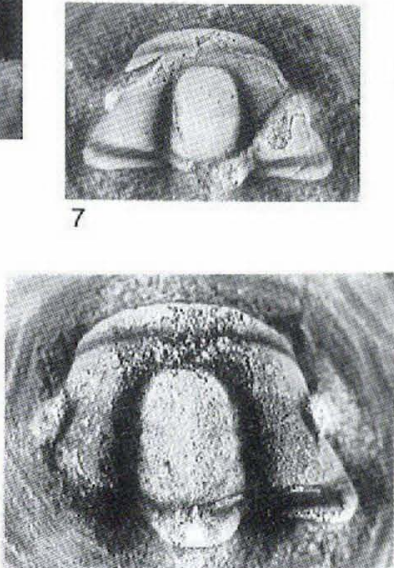

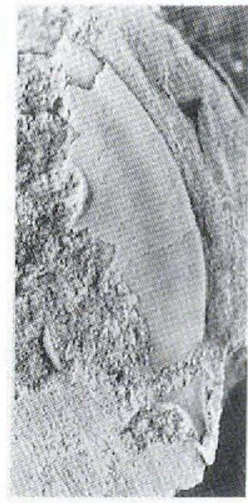

4

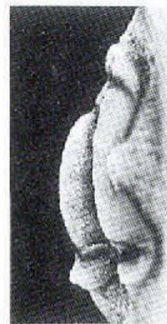

$9 b$

Fig. 26. Specimens of Syspacephalus.

1-4, Syspacephalus sp. 1, all from GGU 298969. 1, cranidium in dorsal (a), frontal (b), and left-lateral (c) views, MGUH 21.304, $\times 6$. 2, cranidium in dorsal (a) and right-lateral (b) views, MGUH 21.305, ×6.3, cranidium, MGUH 21.306, $\times 6.4$, incomplete librigena, MGUH 21.307, $\times 6$.

5-6, Syspacephaius sp. 2, both from GGU 298970. 5, cranidium in dorsal (a), left-lateral (b), and frontal (c) views, MGUH 21.309, $x$ 3. 6, cranidium in dorsal (a) and left-lateral (b) views, MGUH 21.308, $\times 3$; occipital spine was probably broken and healed during life.

7-9, Syspacephalus sp. 3. 7, small cranidium, MGUH 21.310 from GGU 298972, × 7. 8, broken cranidium in dorsal (a), right-lateral (b), and frontal (c) views, MGUH 21.311 from GGU 298971, ×6. 9, weathered, exfoliated cranidium in dorsal (a) and right-lateral (b) views, MGUH 21.312 from GGU $298971, \times 6$. 
abaxially and shallows medially; the occipital ring is moderately large and has a moderately long, slender, hook-like medial spine projecting vertically then backward. The frontal area is relatively short, and the anterior border is wider than the preglabellar field. Anteriorly, the fixigena is relatively narrow, and posteriorly it is wide. The anterior border furrow is shallow and wide, and the posterior border furrow is deep and wide. Eye ridges are usually strong.

Occurrence. Cranidia are abundant in a packstone bed from approximately $56 \mathrm{~m}$ above the base of the Henson Gletscher Formation at locality 1, Nyeboe Land. They are associated with eodiscids and agnostoids indicative of the Ptychagnostus gibbus Interval-zone of Robison (1984).

\section{Syspacephalus sp. 3}

Fig. 26.7-9

Material. Five cranidia in GGU 298971 and 298972.

Remarks. Broken cranidia in GGU 298971 and 298972 resemble specimens of $S$. spinifera Rasetti, 1951, from British Columbia. The major observed difference between specimens is that those from North Greenland have a slightly longer frontal area of the cranidium than do those from British Columbia.

Occurrence. Present in wackestone beds of the Henson Gletscher Formation at locality 1, Nyeboe Land. Associated polymeroid trilobites indicate a correlation with the Glossopleura Zone of the Laurentian shelf.

\section{'Polymerida' incertae sedis: 'Eodiscidae'}

Remarks. Conclusions about the phylogenetic relationships of eodiscid trilobites have differed for more than a century because, as a group, they include characters common to both polymeroids and agnostoids. Kobayashi (1943a, 1943b, 1944) reviewed early interpretations of the relationships and evolution of eodiscids. More recently, they have been considered to be agnostoids (e.g., Howell in Harrington et al., 1959b), ancestors of agnostoids (e.g., Jell, 1975), similar to ancestors of agnostoids (Müller \& Walossek, 1987), and of doubtful assignment (Robison, 1987).

To further evaluate eodiscid relationships, I included six genera of eodiscids in a cladistic analysis with six genera of polymeroids, two condylopygids, three agnostoids, and one nektaspid. The taxa selected represent nine major groups of trilobites present in Lower or Middle Cambrian rocks. The groups are olenellids (represented by Olenellus), redlichiids (represented by Xystridura), ptychopariids (represented by Elrathia), corynexochids (represented by Olenoides), oryctocephalids (represented by Tonkinella and Thoracocare), eodiscids (represented by Eodiscus, Dawsonia, Costadiscus, Pagetia, Pagetides, and Neocobboldia), condylopygids (represented by Condylopyge and Pleuroctenium), agnostoids (represented by Agnostus, Peronopsis, and Ptychagnostus), and nektaspids (represented by Naraoia). For consistency in evaluating all the taxa, 22 characters of adult, dorsal morphology were used (Table 3). Characters of juvenile or ventral morphology, which have been shown to be of importance in analyzing phylogenetic relationships among many trilobites (Fortey, 1990), were not used because they are incompletely known in many of the analyzed taxa. Results on 'polymeroid' taxa using this technique are in general agreement with results obtained previously that incorporated data on the dorsal and ventral morphology of the exoskeleton (Fortey, 1990).

The trilobites were analyzed cladistically using the PAUP (Phylogenetic Analysis Using Parsimony) program (Swofford, 1989). To avoid incorporating a priori assumptions about the significance of different characters in determining affinity, all characters were equally weighted. Transformation states were polarised using the outgroup method. The data set was analyzed using a hypothetical outgroup based on merostomes and crustaceans because identifying the most primitive group of trilobite is contentious (Babcock, 1990b).

Five parsimony trees were discovered, but only the majority-rule consensus tree has been illustrated (Fig. 27). The Agnostida evidently comprises a highly derived, monophyletic group (or clade) from which the eodiscids, condylopygids, and Naraoia are excluded. This interpretation differs from that of Briggs \& Fortey (1989) in which Naraoia and the agnostoids are interpreted as having fewer derived characters than polymeroids. Synapomorphies (shared derived characters) of the agnostoids are a saddle-like labrum, basal lobes on the cephalon, an edge-to-edge cephalothoracic hinge, two segments in the anteroaxis of the pygidium, and highly modified tips on the thoracic segments. The condylopygids also seem to form a clade, being united by the shared derivation of median nodes or ridges on all thoracic segments and an expanded posteroaxis of the pygidium. Lack of a calcified exoskeleton in Naraoia must be interpreted as a secondary loss of a character rather than a symplesiomorphic condition.

Trilobites collectively classified in the order Polymerida (e.g., Robison, 1987), including eodiscids, are apparently not united by synapomorphic characters. Dorsal ecdysial sutures, eye ridges, and articulating half-rings, which were previously interpreted to be synapomorphies 


\section{Table 3. Characters used to express relationships among eodiscid and other trilobites}

Characters and character states used to construct the cladogram (Fig. 27) expressing inferred relationships among eodiscid and other trilobites. Character states are those of holaspid specimens. Generalized primitive characters of crustaceans and merostomes have been used to create a hypothetical outgroup for the purpose of polarizing character transformations. A question mark indicates missing data.

1. Maximum exoskeletal length: greater than $1 \mathrm{~cm}(0)$; less than $1 \mathrm{~cm}(1)$.

2. Cephalic sutures: marginal (0); circum-ocular (1); absent (2)

3. Number of thoracic segments: greater than $5(0) ; 3$ to $5(1)$; $2(2) ; 0$ (3).

4. Shape of labrum: plate-like (0); saddle-like (1).

5. Pleural region of pygidium: segmented $(0)$; effaced (1).

6. Eyes: present, centrally located (0); present, nearly marginal (1); absent (2).

7. Basal lobes: absent (0); present (1).

8. Glabella: short, tapered (0); long, anteriorly expanded (1); short, anteriorly expanded (2); long, tapered (3); long, bulbous anteriorly (4).

9. Cephalothoracic hinge: overlapping (0); edge-to-edge (1).

10. Glabellar segmentation: 3 to 4 lateral furrows $(0)$; single transglabellar furrow (1).

11. Segmentation in pygidial axis: fully segmented (0); 3 segments in anteroaxis (1); 2 segments in anteroaxis (2).

12. Median node or ridge on anteroaxis of pygidium: without node or ridge ( 0 ); with node (1); with ridge (2).

13. Pleural tips of last thoracic segment: posteriorly directed $(0)$; anteriorly directed (1).

14. Median node or ridges on all thoracic segments: absent $(0)$; present (1).

15. Posteroglabella: without node or ridge ( 0$)$; with node (1); with ridge (2).

16. Axis of pygidium: tapered (0); expanded posteriorly (1).

17. Eye ridges: present (0); absent (1).

18. Axial width relative to pleurae: narrow (0); wide (1).

19. Calcification of exoskeleton: absent (0); present (1).
20. Terrace lines on border: present $(0)$; absent (1).

21. Genal spines: present, short to intermediate length (0); present, long (1); absent (2); secondary (3).

22. Borders: not ridge-like (0); ridge-like on cephalon (1); ridge-like on cephalon and pygidium (2).

23. Pygidium: 3 or fewer unreleased segments $(0) ; 4$ or more unreleased segments (1); secondarily reduced (2).

24. Preglabellar furrow: absent (0); present (1).

25. Metafixigenal spine: absent (0); present (1).

26. Palpebral lobes: short to intermediate length ( 0$)$; long (1); absent (2).

\begin{tabular}{lllllll} 
& \multicolumn{7}{c}{ Characters } \\
& \multicolumn{7}{c}{1} & 11111 & 11112 & 22222 & 2 \\
& 12345 & 67890 & 12345 & 67890 & 12345 & 6 \\
\cline { 2 - 7 } Outgroup & 00000 & 00000 & 00000 & 00000 & 00000 & 0 \\
Naraoia & $023 ? 1$ & 20300 & 00000 & 01001 & 20200 & 2 \\
Olenellus & 00000 & 00400 & 00000 & 00010 & 00000 & 0 \\
Xystridura & 01000 & 00400 & 00000 & 00010 & 00101 & 1 \\
Elrathia & 01000 & 00000 & 00000 & 00010 & 00100 & 0 \\
Olenoides & 01000 & 00100 & 00000 & 00010 & 00100 & 0 \\
Thoracocare & 11210 & 10100 & 00000 & 00111 & 12100 & 0 \\
Tonkinella & 01110 & 10100 & 00000 & 00011 & 11100 & 0 \\
Costadiscus & 12100 & 20000 & 00000 & 00011 & 22100 & 2 \\
Pagetides & 11100 & 10000 & 00000 & 00011 & 22100 & 0 \\
Eodiscus & 12100 & 20000 & 00000 & 01011 & 22100 & 2 \\
Pagetia & 11200 & 10000 & 00000 & 00011 & 22100 & 0 \\
Serrodiscus & 12101 & 20000 & 00000 & 01011 & 32100 & 2 \\
Dawsonia & 12200 & 20000 & 00000 & 01011 & 22100 & 2 \\
Neocobboldia & 11100 & 10000 & 00000 & 01011 & 21200 & 0 \\
Peronopsis & 12211 & 21011 & 21101 & 01111 & 22200 & 2 \\
Ptychagnostus & 12211 & 21011 & 21101 & 01111 & 22210 & 2 \\
Agnostus & 12211 & 21011 & 20101 & 01111 & 22210 & 2 \\
Condylopyge & $122 \% 0$ & $202 ? 0$ & 12012 & 11110 & 22200 & 2 \\
Pleuroctenium & 12290 & $202 ? 0$ & 12012 & $1111 ?$ & 32200 & 2 \\
& & & & &
\end{tabular}

acters have not yet been identified for eodiscids. Rather, these trilobites seem to be characterised by an extreme reduction of some characters common in other polymeroids. Some such characters as the labrum, however, seem to be relatively unmodified from the polymeroid condition (see Jell, 1970; Zhang, 1989). Reduction is inferred to have taken place primarily through paedomorphosis (probably progenesis in most examples). Analogous patterns of reduction have been inferred in the evolution of Thoracocare (Robison \& Campbell, 1974) and Tonkinella (McNamara, 1986b), both from oryctocephalid ancestors. On account of the variety of combinations of characters that have been reduced (including eyes, facial sutures, number of thoracic segments, and segmentation in the pleural region of the axis), it is inferred that some expressions of reduction have occurred
The eodiscid genera seem to be polyphyletic from trilobites of the order Polymerida. Synapomorphous chargroup is defined only by the absence of more derived descendants. For convenience, I have continued use of the term 'Polymerida' elsewhere in this paper, even though the taxon seems to be artificial in a phylogenetic sense. 


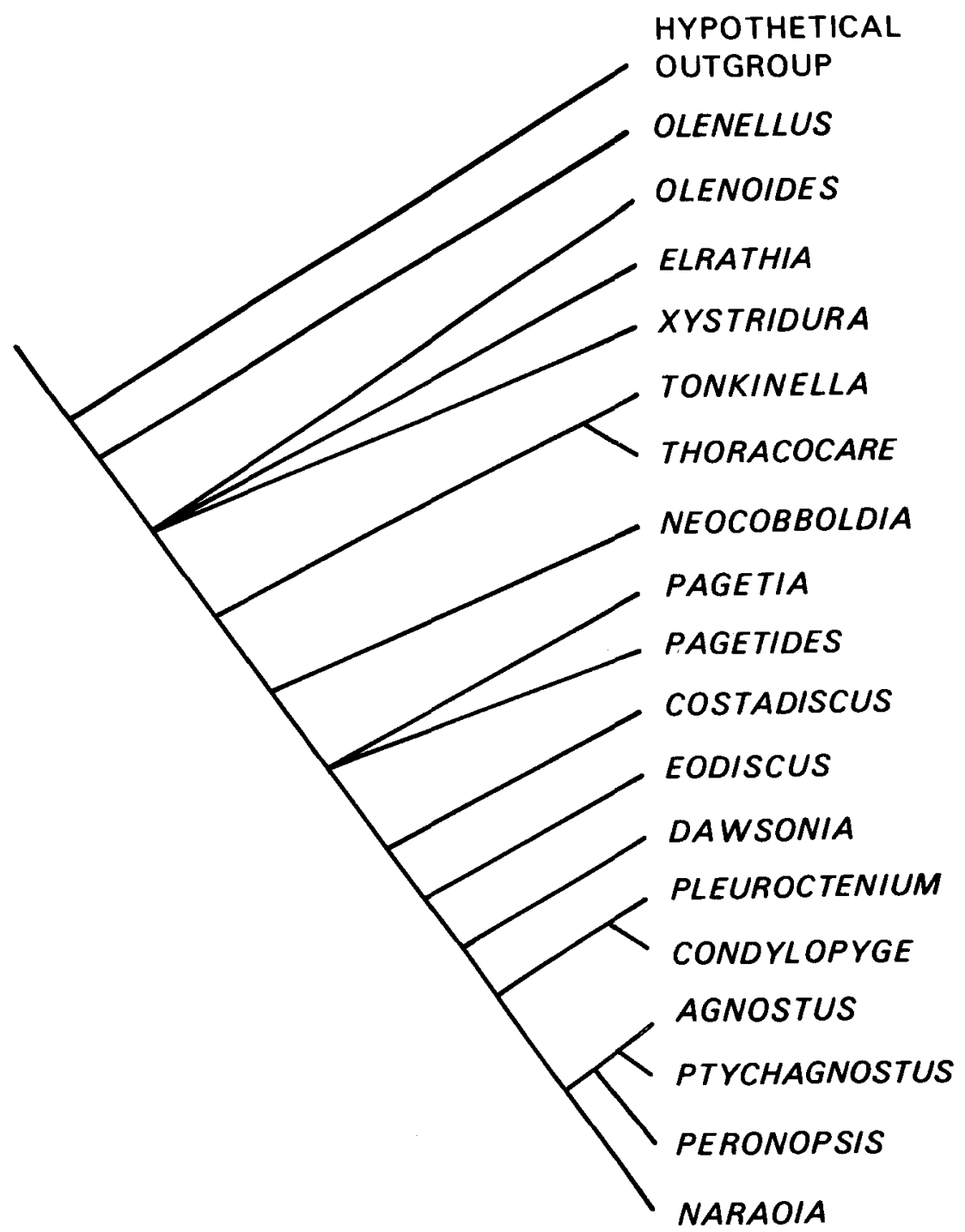

Fig. 27. Majority-rule cladogram illustrating hypothesized phylogenetic relationships among selected trilobite genera, based on characters preserved in holaspides. The outgroup is hypothetical, and based on symplesiomorphic arthropod characters expressed in crustaceans and merostomes. independently in more than one lineage. Jell (1975, 1990), for example, provided cogent arguments for considering blindness to have been achieved independently in at least three eodiscid lineages. The eodiscid condition, therefore, probably represents a grade of evolution in trilobites rather than a clade. Available evidence does not suggest that agnostoids and eodiscids shared a close common ancestor.

In consideration of the uncertain phylogenetic status of the eodicids, I consider all eodiscid genera to be incertae sedis with respect to other polymeroids. This convention follows that discussed by Wiley (1979) for artificial taxa.
Genus Eodiscus Hartt in Walcott, 1884

Type species. Eodiscus pulchellus Hartt in Walcott, 1884, p. 24 (by monotypy). E. pulchellus is a subjective junior synonym of Microdiscus scanicus Linnarsson, 1883, p. 29 (see Rasetti, 1952, pp. 439, 447).

Remarks. Rasetti (1952, p. 447) discussed the generic concept of Eodiscus, and synonymous generic names. His concept of the genus is followed here.

Eodiscus scanicus (Linnarsson, 1883)

Figs 9.2a, 28

Microdiscus scanicus Linnarsson, 1883, p. 29, pl. 4, figs 17, 18; Grönwall, 1902, p. 79 


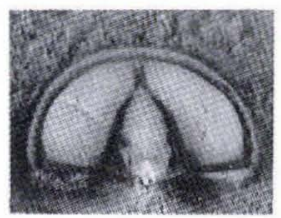

1

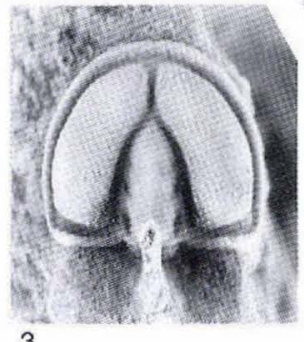

3

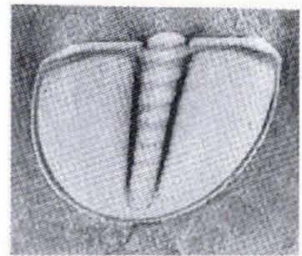

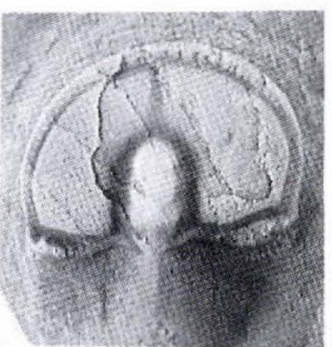

$2 a$

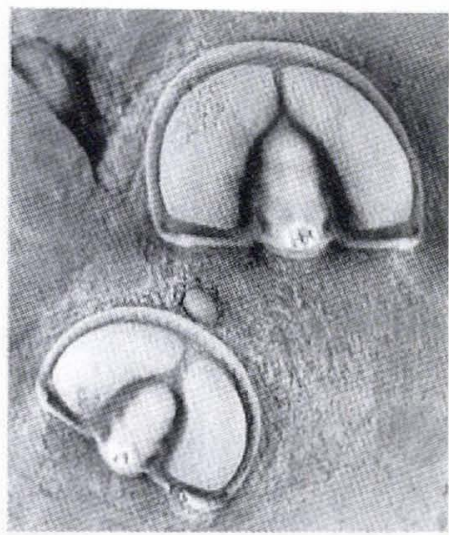

5

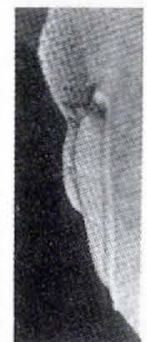

$2 \mathrm{~b}$
Fig. 28. Eodiscus scanicus (Linnarsson). All specimens from GGU 319790, unless otherwise stated.

1, small cephalon, MGUH 21.313, × 10. 2, partly exfoliated cephalon with occipital ring in dorsal (a) and left-lateral (b) views, MGUH 21.314 from GGU 298969, × 7. 3, partly exfoliated cephalon, MGUH 21.315, × 7. 4, pygidium, MGUH $21.316, \times 7.5$, two cephala, MGUH 21.317 (above) and MGUH 21.318 (below), $\times 7$.

Microdiscus punctatus Salter. Whiteaves, 1878, p. 225; Walcott, 1884, p. 24, pl. 2, fig. 1; Lesley, 1889, p. 405, fig. 1; Lake (in part), 1907, p. 36; Nicholas (in part), 1916, p. 460

Eodiscus pulchellus Hartt in Walcott, 1884, p. 24; Grabau \& Shimer, 1910, p. 248, fig. 1543, h, i; Raymond, 1913, p. 103 , fig. 2; Kobayashi, 1943a, p. 39; Kobayashi, 1944, pp. 52, 53, $56-58$

Microdiscus punctatus var. puichellus Hartt. Matthew, 1886, p. 74 , pl. 7 , fig. 12

Microdiscus punctatus var. precursor Matthew, 1886, p. 75, pl. 7, fig. 13

Microdiscus precursor Matthew. Matthew, 1896, p. 239, pl. 17 , fig. 7, text-fig

Microdiscus puichellus (Hartt). Matthew, 1896, p. 242, pl. 17 , fig. 8

Eodiscus scanicus (Linnarsson). Raymond, 1913, p. 104, fig. 10; Yanishevski, 1950, pl. 1, figs 10-14; Rasetti, 1952, pp. 447, 448, pl. 53, figs 7-16, pl. 54, figs 10-16; Hutchinson, 1962, p. 59, pl. 2, figs 1, 2; Rushton, 1974, p. 89; Morris, 1988, p. 91; Robison, 1994, fig. 27.1 (left)

Eodiscus praecursor (Matthew). Raymond, 1913, p. 103, fig. 8
Microdiscus punctatus var. scanicus Linnarsson. Illing, 1916, p. 423, pl. 33, figs 11,12

?Microdiscus cf. M. punctatus Salter. Strand, 1929, p. 348

Spinodiscus punctatus scanicus (Linnarsson). Kobayashi, 1943a, p. 39; Kobayashi, 1944, p. 57

Spinodiscus matthewi Kobayashi, 1943a, p. 39; Kobayashi, 1944, pp. 56-58

Deltadiscus praecursor Kobayashi, 1943a, p. 39; Kobayashi, 1944, p. 60, pl. 1, fig. 10 (also printed as Deliacandus) Dawsonia canadensis Kobayashi, 1944, p. 60, pl. 2, fig. 14 Eodiscus punctatus scanicus (Linnarsson). Westergård, 1946, pp. $24-26$, pl. 1, figs 6-11

Lectotype. Cephalon (selected from Linnarsson's syntypes) by Westergård, 1946, p. 26), SGU Type 5602 .

New material. Numerous sclerites in GGU 298969, 298974, 319789, and 319790.

Remarks. This species was adequately diagnosed by Westergård (1946, pp. 24-26), who regarded it as a subspecies of Eodiscus punctatus (Salter, 1864) because intermediates are recognised between it and E. punctatus. I follow Rasetti (1952) and Hutchinson (1962) in assigning this taxon species rank because of significant differences in the stratigraphic ranges of E. scanicus and E. punctatus, even though their ranges seem to be bridged by morphological intermediates.

Occurrence. Common in packstone approximately 71 to $73 \mathrm{~m}$ above the base of the Henson Gletscher Formation at locality 1, and in the basal beds of the Kap Stanton Formation at locality 2. In North Greenland, as in northern and western Europe, E. scanicus is associated with trilobites of the Ptychagnostus atavus Interval-zone of Robison (1984). E. scanicus is widespread in western Europe. Material has been collected from Sweden, Norway, and Great Britain (Westergård, 1946, p. 26). In accreted terranes of eastern North America, E. scanicus has been reported from the Paradoxides hicksii Zone of eastern Newfoundland (Howell, 1925, as reassigned by Westergård, 1946, p. 26; see also Hutchinson, 1962) and from the Paradoxides abenacus Zone of New Brunswick (Rasetti, 1952, p. 448).

\section{Genus Costadiscus n. gen.}

Etymology. From Latin, costa, rib, and discus, disk; in reference to the multiribbed pygidium.

Type species. Costadiscus minutus n. gen., n. sp.

Diagnosis. Cephalon semicircular, wider than long; glabella narrow, tapered, angular anteriorly; preglabellar 
field wide; cheeks separated by preglabellar median furrow; border narrow laterally, expanding anteriorly; eyes absent; occipital ring expanded into spine; baccula present; posterior border furrow joins baccular furrow. Holaspid thorax with three segments; segment 1 transversely narrower than segments 2 or 3 ; pleural tips point backward in segment 1 , forward in segments 2 and 3. Pygidium semicircular, wider than long. Axis narrow, not reaching posterior border furrow, having 8 segments. Pleural field having 8 segments, continuous to posteromedial line. Border narrow.

Remarks. Trilobites of this genus are characterised by a narrow axis, a glabella that is angular anteriorly, a lack of eyes and facial sutures, a border furrow that joins the baccular furrows, three thoracic segments in the holaspid period, a wide border on the anterior cephalon, a narrow border on the pygidium, and a pygidium having deep furrows in the pleural field and eight pleural segments.

The cephalon of Costadiscus n. gen. is most similar to that of Eodiscus Hartt in Walcott, 1884, but the pygidium resembles that of Dawsonia Hartt in Dawson, 1868. If sclerites are found separately, they could easily be confused with Eodiscus or Dawsonia. The cephalon of Costadiscus differs from Eodiscus primarily in the glabella, which is angular anteriorly, and in the posterior border furrow, which joins the baccular furrow. The pygidium of Costadiscus differs from Dawsonia in having one or two more axial rings, three more segments in the pleural field, and a much narrower border.

At present, only the type species, C. minutus n. sp., is included in Costadiscus.

\section{Costadiscus minutus n. sp.}

Fig. 29

Etymology. From Latin, minutus, little or small; in reference to the small exoskeleton of this species.

Holotype. Nearly complete specimen, MGUH 21.322.

Material. Four nearly complete specimens, and 15 disarticulated specimens in GGU 298969, 319789, and 319790 .

Diagnosis. As for genus.

Description. Cephalon about 1.4 times wider than long exclusive of occipital ring and spine. Glabella high, reaching greatest width across $\mathrm{L} 1 ; \mathrm{S} 1$ deep, convex, oblique backward; S2 deep laterally, shallowing medially, simple, straight. Occipital furrow deep at sides, moderately impressed and straight across axis. Occipital spine reaching to third thoracic segment in holaspid; median node of variable expression at base of spine. Cheeks higher than glabella, highest about midway across, rapidly sloping to anterior and lateral border furrow; preglabellar furrow distinct. Baccula low, subtriangular; low ridges connect inner part of baccular furrow to occipital ring. Holaspid genal angle rounded, meraspid genal angle angular. Ridges on anterior and lateral border low, narrow, closely spaced.

Holaspid thorax with three segments, axis moderately high, pleurae flattened. Segment 1 transversely narrower than cephalon, segments 2 and 3 about as wide as cepha-
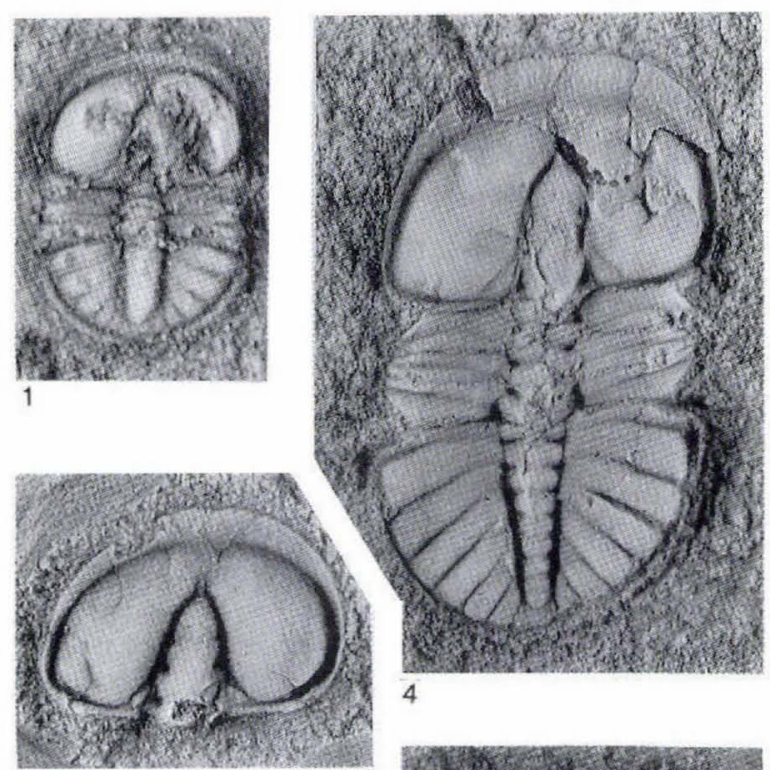

2

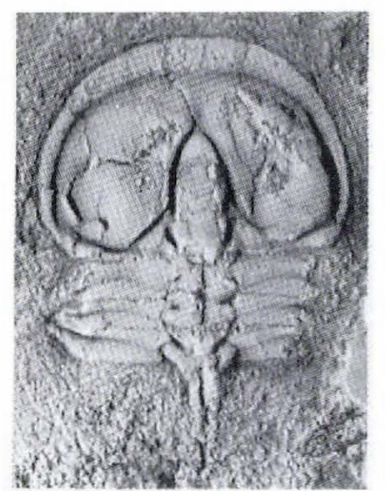

3

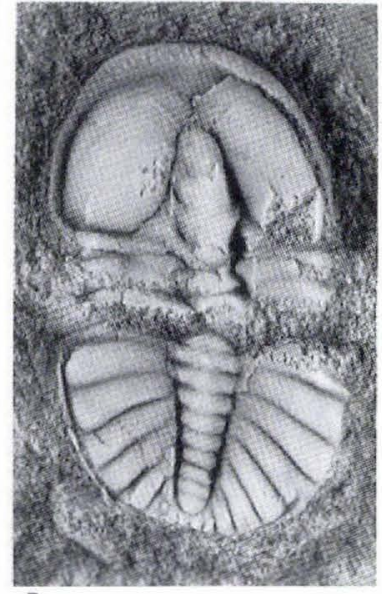

5

Fig. 29. Costadiscus minutus n. gen., n. sp. All specimens from GGU 298969.

1, small exoskeleton, MGUH 21.319, × 8. 2, cephalon, MGUH $21.320, \times 7.3$, specimen lacking pygidium but showing spines extending from occipital ring and axis of third segment, MGUH 21.321, × 7. 4, holotype exoskeleton, MGUH 21.322, × 7. 5, specimen lacking third thoracic segment, MGUH $21.323, \times 7$. 
lon. Pleural tip rounded and posterolaterally directed in segment 1 , angular and anterolaterally directed in segments 2 and 3. Pleural furrows distinct; in segment 1 strongly concave near axial furrow, strongly convex laterally and distally; in segment 2 moderately concave near axial furrow, nearly straight laterally and distally; in segment 3 strongly concave near axial furrow, moderately convex laterally then turned strongly forward distally. Axis about 1.5 times wider than maximum glabellar width; third axial ring with median spine reaching to about middle of pygidium.

Pygidium about 1.4 times wider than long. Axis narrow, gradually tapering, not reaching posterior border furrow, higher than pleural furrow, having eight segments plus terminal piece; first axial ring with small median node; ring furrows deep, continuous for entire length; axial furrows deep. Pleural field high, highest about midway across, rapidly sloping to border furrow, with eight segments, interpleural furrows deep distally, gradually shallowing medially. Border narrow, anterior border thickened laterally; articulating facets truncating anteropleural corners.

Dorsal surface smooth except for anterior and lateral cephalic border, which is finely granulated.

Ontogeny. Growth stages represented are meraspid degrees 1 and 2, and several holaspid instars. Protaspides have not been recognised in $C$. minutus. Normal size increase in $C$. minutus is accompanied by the following morphological changes during the meraspid and holaspid periods: retraction of the glabella, change in shape of the genal angles from angular to broadly rounded, increase in number of thoracic segments to three, movement of segments forward from the anterior of the pygidium, increase in number of both pygidial axial rings and pygidial pleurae from five in meraspid degree 1 to eight in holaspid period, relative decrease in width of the pygidial border, reduction of relief of both the cephalon and pygidium, and development of granulation on the cephalic border during the holaspid period. The occipital and medial thoracic spines are broken in all studied meraspides, and any changes in these characters are unknown.

Occurrence. Common in mudstone and packstone beds approximately 71 to $73 \mathrm{~m}$ above the base of the Henson Gletscher Formation at locality 1 and in the basal beds of the Kap Stanton Formation at locality 2. The species is associated with trilobites indicative of the Ptychagnostus atavus Interval-zone of Robison (1984).

\section{Genus Opsidiscus Westergård, 1949}

Aulacodiscus Westergård, 1946, p. 26; Hupé, 1953, p. 170; not Aulacodiscus Douvillé, 1921 (Gastropoda; see Westergård, 1949, p. 606)

Opsidiscus Westergård, 1949, p. 606; Rasetti in Harrington et al., 1959b, p. O188; Pokrovskaya, 1959, p. 177; Pokrovskaya in Chernysheva, 1960, p. 56; Poletaeva \& Romanenko, 1970 , p. 73; Jago, 1972b, pp. 227-229; Jell, 1975, pp. 75-78

Type species. Aulacodiscus bilobatus Westergård (1946, pp. 26-28), by original designation (Westergård, 1949).

Remarks. The concept and content of this genus were thoroughly reviewed by Jell (1975, pp. 75-78).

\section{Opsidiscus longispinus n. sp. \\ Fig. 30}

Etymology. From Latin, longus, long, and spina, spine; in reference to the elongate occipital spine.

Holotype. Cephalon, MGUH 21.325.

Material. Three cephala in GGU 319789 and 319790.

Diagnosis. Opsidiscus having straight medial margin on cephalon; posterior glabellar part wider and more convex than anterior part, transglabellar furrow distinct; occipital spine long, slender; eye convex, located subcentrally on gena; eye ridge strongly curved, convex near axial furrow, indistinct near palpebral lobe; border furrow without scrobicules.

Description. Cephalon semicircular in outline, anterior margin straight medially, anterolateral corner wellrounded, posterolateral corner geniculate. Glabella bi-

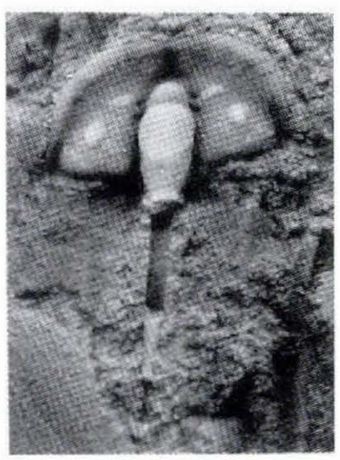

1

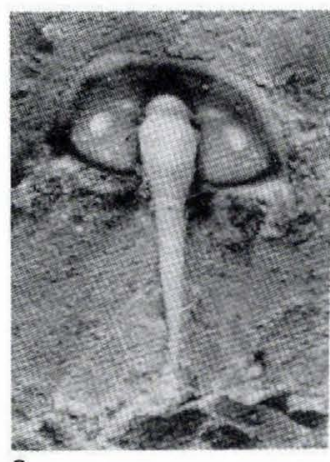

2
Fig. 30. Opsidiscus longispinus n. sp., both from GGU 319790. 1, cephalon with broken occipital spine, MGUH 21.324, × 16.2, holotype cephalon, MGUH 21.325, × 16. 
lobed; anterior part narrow, short, convex, and rounded anteriorly; transglabellar furrow straight; posterior part about 1.5 times length of anterior part, strongly convex, elevated well above gena and anterior part, expanding slightly forward; lateral furrows absent. Occipital spine long, thick, directed away from cephalon at about 10 degree angle; length beyond posterior margin of occipital ring about 1.6 times cephalic length exclusive of spine. Occipital ring subequal in width with widest part of posterior glabella, continuous with occipital spine. Occipital furrow indicated only at sides by distinct pit. Axial furrow moderately deep, moderately wide in front, narrower at side, with distinct pits at intersection with transglabellar furrow. Bacculae absent. Genae convex, sloping at sides, moderately sloping at front, separated by shallow preglabellar median furrow. Eye convex, moderately long, wide, slightly crescentic; located subcentrally on gena. Eye ridge originates in axial furrow about one-third distance from back of anterior part of glabella, forms narrowly curved arc to anterior end of palpebral lobe; adaxial one-half of length convex, abaxial one-half indistinct. Facial suture absent. Preglabellar field subequal in length with anterior part of glabella. Border furrow shallow, moderately wide in front, narrowing and slightly deepening laterally, narrow and deep posteriorly; pits absent. Border narrow, slightly convex anteriorly and laterally; slightly narrowed at posterolateral corner, upturned at genal angle, rapidly narrowing toward occipital ring. Surface of cephalon smooth or with several small granules on cheek behind eye.

Thorax and pygidium unknown.

Remarks. In characters of the cephalon, O. longispinus differs from all described species of the genus by having a distinctly bipartite glabella with a posterior part that is markedly wider and more convex than the anterior part, by having a convex eye that is located near the middle of the gena, and by having a strongly arcuate eye ridge. Aside from $O$. longispinus, complete occipital spines are known from $O$. altaicus Poletaeva in Poletaeva \& Romanenko (1970), O. antarcticus (Palmer \& Gatehouse, 1972), O. brevicaudatus Jell (1975), O. depolitus Romanenko in Poletaeva \& Romanenko (1970), O. microspi$n u s$ Jell (1975), and $O$. teretistes Jell (1975). Among these species, the spine of $O$. longispinus is by far the longest. It is also evenly tapered, unlike that in $O$. altaicus, $O$. brevicaudatus, and $O$. teretistes. Besides $O$. longispinus, only $O$. antarcticus and some specimens of $O$. argusi Jago (1972b) lack scrobicules in the border furrow. The presence of granules over the surface of the cephala of $O$. argusi and $O$. bilobatus (Westergård, 1946), and the presence of functional facial sutures in $O$. antarcticus, further distinguish these species from $O$. longispinus.

Occurrence. Present in a packstone bed of the basal Kap Stanton Formation at locality 2. It is associated with trilobites indicative of the Ptychagnostus atavus Intervalzone of Robison (1984).

\section{Undetermined corynexochoid}

Fig. 31.1

Remarks. A single, incomplete, exfoliated cranidium, possibly belonging to Olenoides, is present in GGU 298970. The specimen is small. Its glabella is parallelsided, moderately convex, and elevated slightly above the fixigena. It extends well beyond the anterolateral corner of the cranidium and is unfurrowed. The occipital furrow is distinct and a deep pit is developed at the side. The occipital ring has a long, stout medial spine. The fixigena is narrow anteriorly and very wide behind the palpebral lobe. The axial furrow is distinct, and an eye ridge is not evident.

It is possible that this specimen is a small individual of Olenoides sp., described above from GGU collection 298970. The present lack of specimens intermediate in size between this specimen and a specimen of Olenoides sp. (Fig. 14.1), however, leave some reason for doubt.

Occurrence. Present in a wackestone bed approximately $56 \mathrm{~m}$ above the base of the Henson Gletscher Formation at locality 1, Nyeboe Land. It is associated with trilobites indicative of the Ptychagnostus gibbus Interval-zone of Robison (1984).

\section{Undetermined ptychoparioid 1}

Fig. 31.2

Remarks. Two small, distinctive cranidia are in GGU 298971. They are moderately convex and have a subquadrate glabella with a low, weak, longitudinal ridge medially. Lateral glabellar furrows are moderately deep. The S1 and S2 are geniculate, and the posterior branches are more deeply impressed than the anterior branches. The S3 are straight and slightly oblique forward. The occipital ring is subtriangular and long, being approximately one-third the glabellar length. It extends backward to a sharp point, but does not end in a true spine. A low, weak, longitudinal ridge is present medially. The anterior border is not preserved. The posterior border is convex and narrower than the border furrow. It is backwardly deflected at about midlength. The axial furrow is deep, and weak fossula are present. The fixigenae appear to be narrow although the margins are broken. Strong eye 
Fig. 31. Undetermined polymeroid trilobites.

1, Undetermined corynexochoid. Incomplete cranidium, MGUH 21.326 from GGU $298970, \times 4.5$.

2, Undetermined ptychoparioid 1. Incomplete cranidium in dorsal (a) and left-lateral (b) views, MGUH 21.327 from GGU 298971, × 7 .

3. Undetermined ptychoparioid 2. Incomplete cranidium in dorsal (a), frontal (b), and right-lateral (c) views, MGUH 21.328 from GGU $298970, \times 6$.

4-6, Undetermined ptychoparioid 3, all from GGU 298970. 4, incomplete cranidium, latex cast of counterpart (a) and part (b), MGUH 21.329; small cranidium of Syspacephalus sp. 2 and cephalon of agnostoid are associated with the counterpart; $\times 4$. 5 , axial region of cephalon, $\mathrm{MGUH}$ $21.330, \times 4.6$, cranidial fragment including part of border. MGUH $21.331, \times 4$.

7, Undetermined ptychoparioid 4. Incomplete cranidium, MGUH 21.332 from GGU 298970, × 2 .

8, Undetermined ptychoparioid 5. Incomplete pygidium, MGUH 21.333 from GGU 298973, x 8 .

9, Undetermined ptychoparioid 6. Incomplete librigena with some of the genal spine attached, preserved as part and counterpart ( $a$ and $b$ ), MGUH 21.334 from GGU $298974, \times 1$.
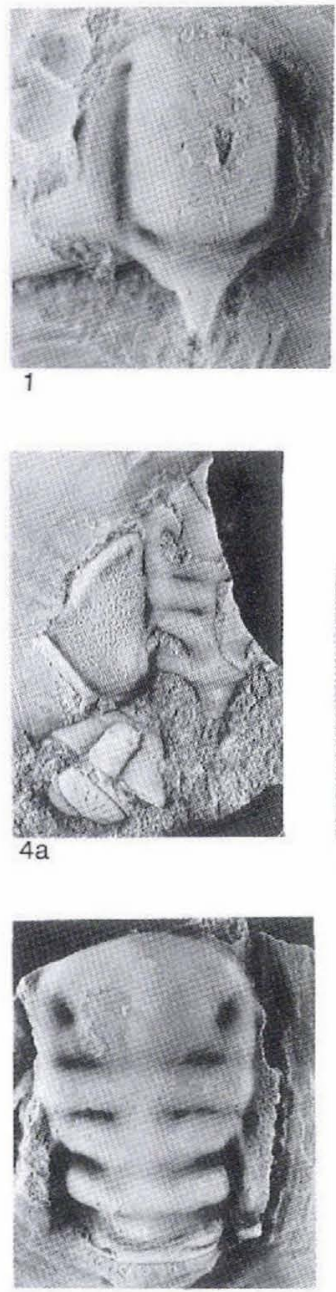

5
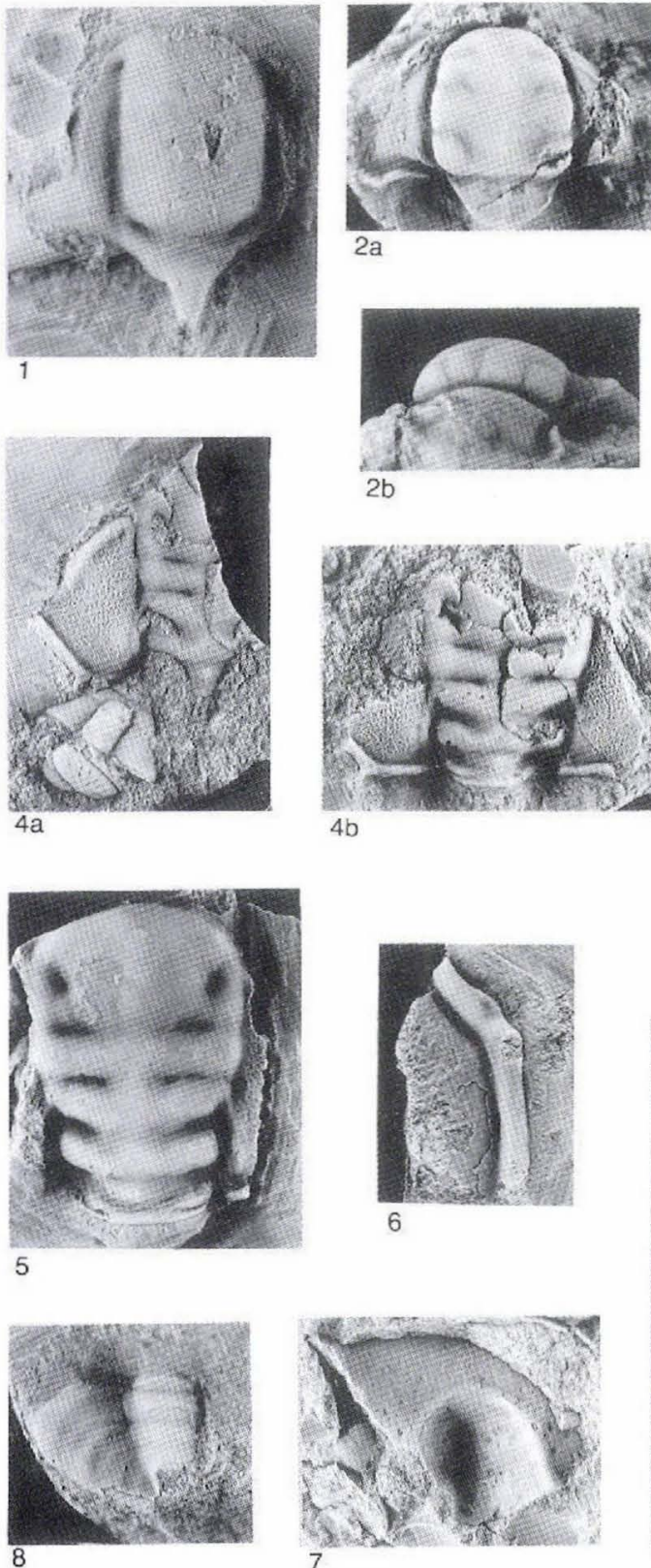

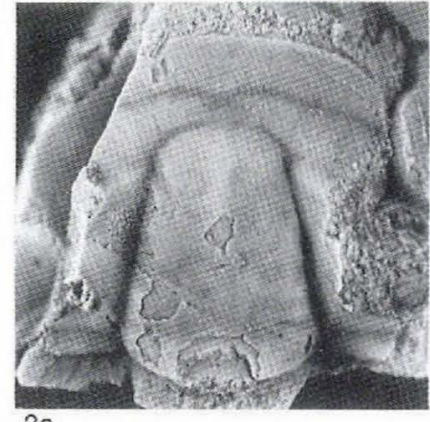

$3 a$

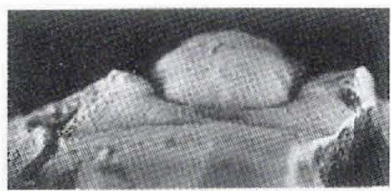

$3 b$

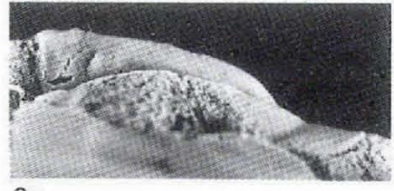

$3 c$

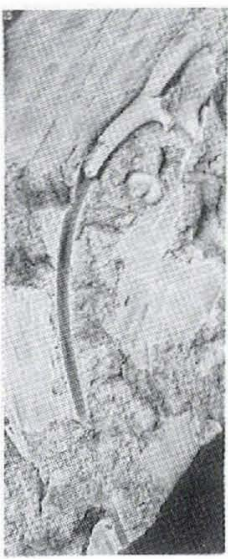

$9 a$

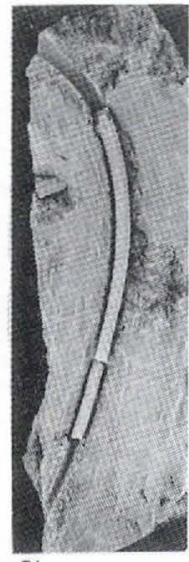

$9 b$ ridges, extending strongly obliquely backward from the fossulae, are present.

In general aspect, the cranidium appears to resemble some described species of Glaphyraspis and Welleraspis. Among preserved characters of the cranidium, however, the new specimens differ from Welleraspis and Glaphyraspis in lacking a true occipital spine, having geniculate S1 and S2 lateral glabellar furrows, or having a backwardly deflected posterior border. Critical characters of the anterior border and the palpebral lobes are not preserved. The undetermined cranidia are associated with a polymeroid fauna indicative of the Glossopleura Zone, and are substantially older than either Glaphyraspis or Welleraspis.

Occurrence. Present in a wackestone bed approximately $42 \mathrm{~m}$ above the base of the Henson Gletscher Formation at locality 1, Nyeboe Land. It is associated with trilobites indicative of the Glossopleura Assemblage-zone of Robison (1976). 


\section{Undetermined ptychoparioid 2 \\ Fig. 31.3}

Remarks. A single fragmentary cranidium in GGU 298970 having some similarities with Elrathiella is left in open nomenclature. The specimen is large and relatively low in front and lateral profile. It has a long, slightly tapering glabella that shows four weak pairs of lateral furrows. A weak ridge-like structure extends the length of the glabella. The occipital ring is broken. The occipital furrow is moderately deep at the sides but shallows medially. The axial furrow is moderately deep, and a pair of fossulae is present. Distinct eye ridges are present. The anterior border is wide. The anterior border furrow is shallow and wide, and has a slight backward deflection medially. At its widest, the preglabellar field is about three-quarters the length of the anterior border. Although broken, the anterior parts of the fixigenae were probably wide. The posterior parts of the fixigenae and the palpebral lobes are missing. Type 4 caeca radiate into the preglabellar field.

Occurrence. Present in a packstone bed approximately 56 $m$ above the base of the Henson Gletscher Formation at locality 1 , Nyeboe Land. It is associated with trilobites indicative of the Ptychagnostus gibbus Interval-zone of Robison (1984).

\section{Undetermined ptychoparioid 3}

Figs 31.4-31.6

Remarks. Several broken cranidia of a distinctive polymeroid are present in GGU 298970. The glabella is convex, expanded forward, and contains four deep lateral furrows; S1 is confluent, straight, slightly oblique backwards, and deepest at the sides; S2 and S3 are straight, transverse, and deepest near mid-course; S4 is backwardly directed and pit-like. The occipital ring is exceptionally narrow, and the occipital furrow is unusually wide and deep. The axial furrow is narrow. Little is known of the rest of the cranidium. It is evidently flat, possessing a rather long palpebral lobe, and has a rather narrow upturned border. A putative metafixigenal spine is present at each posterolateral corner. A network of fine raised lines covers at least the posterior part of the fixigenae.

In axial characters, this taxon resembles some paradoxidid trilobites, especially Centropleura, Anopolenus, and Clarella, but none of these taxa has such a short palpebral lobe or occipital ring.

Occurrence. Present in a packstone bed approximately 56 $\mathrm{m}$ above the base of the Henson Gletscher Formation at locality 1, Nyeboe Land. It is associated with trilobites indicative of the Ptychagnostus gibbus Interval-zone of Robison (1984).

\section{Undetermined ptychoparioid 4}

Fig. 31.7

Remarks. Several cranidial fragments in GGU 298970 cannot be assigned to genus. They are characterised by a rather wide border and fixigenae having large, closely spaced granules. The fragments resemble fixigenae of some genera of alokistocarids.

Occurrence. Present in a packstone bed approximately 56 $m$ above the base of the Henson Gletscher Formation at locality 1, Nyeboe Land. It is associated with trilobites indicative of the Ptychagnostus gibbus Interval-zone of Robison (1984).

\section{Undetermined ptychoparioid 5}

Fig. 31.8

Remarks. A single broken pygidium in GGU 298973 is unassigned. It apparently has a subhemispherical outline, a convex, slightly tapering axis, and a nearly flat pleural area. Three rings and a terminal piece are present in the axis. Three pairs of wide and shallow pleural furrows and two interpleural furrows are present in the pleural region.

Occurrence. Present in a wackestone bed approximately $42 \mathrm{~m}$ above the base of the Henson Gletscher Formation at locality 1 , Nyeboe Land. It is associated with trilobites indicative of the Glossopleura Assemblage-zone of Robison (1976).

\section{Undetermined ptychoparioid 6}

Fig. 31.9

Remarks. Several elongate, tubular, and moderately curved genal spines are present in GGU 298974. One specimen has the posterolateral corner of the librigena attached. The genal spines are approximately circular in cross section and smooth externally. Their affinities are unknown although they resemble the genal spines of some Late Cambrian olenid trilobites.

Occurrence. Present in a wackestone bed approximately $73 \mathrm{~m}$ above the base of the Henson Gletscher Formation at locality 1, Nyeboe Land. It is associated with trilobites indicative of the Ptychagnostus atavus Interval-zone of Robison (1984). 
Acknowledgements. Trilobites from North Greenland that were used in this study were collected by J. S. Peel (formerly Geological Survey of Greenland; now Uppsala University), A. K. Higgins (Geological Survey of Greenland), M. R. Blaker (formerly University of Keele), and J. R. Ineson (Geological Survey of Denmark). J. S. Peel arranged for the loan of these fossils. Loans of comparative material from Sweden and Denmark were arranged by F. J. Collier (formerly U.S. National Museum of Natural History; now Museum of Comparative Zoology, Harvard University), J. Thompson (U.S. National Museum of Natural History), and A. Kamb (University of Kansas Museum of Invertebrate Paleontology). F. J. Collier and J. Thompson kindly arranged for study space and access to collections at the U.S. National Museum of Natural History during 1989.

I thank R. A. Robison (University of Kansas) for generously providing his time and advice during the completion of this project. I also thank R. L. Kaesler, L. F. Dellwig, and R. H. Goldstein (all University of Kansas), J. R. Ineson (Geological Survey of Denmark), J. S. Peel and V. Berg-Madsen (Palaeontological Museum, Uppsala) for reviewing manuscripts. C. G. Maples (Kansas Geological Survey) and E. O. Wiley (University of Kansas) provided access to computer facilities or advice on statistical and phylogenetic methodology. I have also benefitted from stimulating conversations with F. E. Abegg (Chevron Production Company), M. A. Beebe (Austin Peay State University), J. Bergström (Swedish Museum of Natural History), S. M. Bergström (Ohio State University), D. E. G. Briggs (University of Bristol), K. R. Evans (University of Kansas), R. A. Fortey (British Museum (Natural History)), K. C. Hood (Exxon Company, U.S.A.), and A. R. Palmer (Institute for Cambrian Studies). I. A. Solovjev (UNII Ocean-geologia PGO Sevmorgeologia) provided some information on Siberian trilobites. M. Rowell (Lawrence, Kansas) translated some Russian literature into English. Drafting and darkroom assistance from K. Tyler and B. Daye (Ohio State University) is gratefully acknowledged.

This research was supported in part by National Science Foundation grants EAR-8519324, EAR-8720333, and EAR-9104450 to R. A. Robison, an American Association of Petroleum Geologists Grant-in-Aid, and a Sigma Xi Grant-inAid of Research. Additional support was provided through the University of Kansas Department of Geology in the form of research assistantships, research fellowships, a summer scholarship, the R. C. Moore and Erasmus Haworth scholarships, and a grant for incidental supplies. The Kansas Geological Survey provided a research assistantship during the 1989-90 academic year. The Graduate Division of The University of Kansas provided a grant to conduct studies at the U.S. National Museum of Natural History in 1989. Preparation of the final manuscript was completed with funding from a Seed Grant from The Ohio State University.

\section{References}

Angelin, N. P. 1851 [dated 1852]: Palaeontologia Svecica: pars I: iconographia crustaceorum formationis transitionis. $24 \mathrm{pp}$. Lund: Weigel.
Angelin, N. P. 1854: Palaeontologia Scandinavica: pars I: crustacea formationis transitionis, 21-92. Lund: Weigel.

Angelin, N. P. 1878: Palaeontologia Scandinavica: pars I: crustacea formationis transitionis. Fasciculi I \& II, 1-24, 21-92. Holmiae (Stockholm): Samson \& Wallin.

Archer, A. W. \& Maples, C. G. 1987: Monte Carlo simulation of selected binomial similarity coefficients (I): effect of number of variables. Palaios 2, 609-617.

Babcock, L. E. 1990a: Biogeography, phylogenetics, and systematics of some Middle Cambrian trilobites from open-shelf to basinal lithofacies of North Greenland and Nevada. Unpublished Ph.D. dissert., Univ. Kansas, 222 pp.

Babcock, L. E. 1990b: Phylogenetic relationships among Cambrian trilobites. Geol. Soc. Amer. Abstr. Prog. 22(7), A265.

Babcock, L. E. 1991: Debris beds containing mixed faunal representatives from shelf-margin biofacies: a tool for use in terrane analysis. Geol. Soc. Am. Abstr. Prog. 23(3), 2.

Babcock, L. E. 1993: Trilobite malformations and the fossil record of behavioral asymmetry. J. Paleont. 67, 217-229.

Babcock, L. E. in press: Arthropoda, class Trilobita. In Feldmann, R. M. (ed.) Fossils of Ohio. Bull. Ohio Dept. Nat. Res., Div. geol. Survey $\mathbf{7 0 .}$

Babcock, L. E. 1994: Biogeography and biofacies patterns of Middle Cambrian polymeroid trilobites from North Greenland: palaeogeographic and palaeo-oceanographic implications. Bull. Gronlands geol. Unders. 169 (this volume).

Babcock, L. E. \& Robison, R. A. 1989: Paleobiogeographic significance of Middle Cambrian trilobites from North Greenland. Geol. soc. Am. Abstr. Prog. 21(6), A340.

Barrande, J. 1852: Systeme silurien de centre de la Bohême 1, 935 pp. Prague and Paris: published by the author.

Beecher, C. E. 1895: The larval stage of trilobites. Am. Geol. 16, 165-196.

Beecher, C. E. 1897: Outline of a natural classification of the trilobites. Am. J. Sci. 4 ser., 3, 89-106.

Berg-Madsen, V. 1985: The Middle Cambrian of Bornholm, Denmark: a stratigraphical revision of the lower alum shale and associated anthraconites. Geol. Fören. Stockh. Förhandl. 106, 357-376.

Bergström, J. \& Levi-Setti, R. 1978: Phenotypic variation in the Middle Cambrian trilobite Paradoxides davidis Salter at Manuels, SE Newfoundland. Geolog. Palaeont. 12, 1-40.

Blaker, M. R. 1986: Notes on the trilobite faunas of the Henson Gletscher Formation (Lower and Middle Cambrian) of central North Greenland. Rapp. Gronlands geol. Unders. 132, 65-73.

Blaker, M. R. 1991: Early Cambrian trilobites from North Greenland. Keele Univ. Unpublished Ph.D thesis, 286 pp.

Briggs, D. E. G. \& Fortey, R. A. 1989: The early radiation and relationships of the major arthropod groups. Science 246, 241-243.

Brøgger, W. C. 1878: Om paradoxidesskifrene ved Krekling. Nyt Mag. Naturvid. 24, 18-88.

Campbell, L. D. 1971: Occurrence of 'Ogygopsis shale' fauna in southeastern Pennsylvania. J. Paleont. 45, 437-440.

Chernysheva, N. E. 1953: [Middle Cambrian trilobites from eastern Siberia, part 1]. Moscow: Vses. Nauch.-Issled. geol. Inst. (VSEGEI), 94 pp. [In Russian.]

Chernysheva, N. E. (ed.). 1960: [Principles of paleontology: 
arthropods, trilobites and crustaceans]. Moscow: Gosudar. Nauchno-Tekh. Izd. Lit. Geol. Okhr. Nedr., 515 pp. [In Russian.]

Chernysheva, N. E. 1961: [Cambrian stratigraphy of Aldan anticline and paleontological basis of separation of Amginsk Formation]. Trudy Vses. Nauch.-Issled. geol. Inst. (VSEGEI) 49, 278 pp. [In Russian.]

Chernysheva, N. E. 1980: [The genus Solenopleura (Trilobita)]. Paleont. Zhur. 3, 65-73. [In Russian.] [English translation: Paleont. J. (1980), 3, 72-80.]

Cobbold, E. S. \& Pocock, R. W. 1934: The Cambrian area of Rushton (Shropshire). Phil. Trans. R. Soc. London B 223, 305-409.

Cooper, G. A. et al. 1952: Cambrian stratigraphy and paleontology near Caborca, northwestern Sonora, Mexico. Smithson. misc. Collns 119(1), $184 \mathrm{pp}$.

Cooper, R. A., Jago, J. B., Laird, M. G., McKinnon, D. I. \& Simes, J. E. 1976: Biostratigraphy of Middle and Upper Cambrian faunas from northern Victoria Land, Antarctica. 25 Int. geol. Congr., Sydney, Abstr. 1, 300 only.

Cooper, R. A., Jago, J. B., Rowell, A. J. \& Braddock, P. 1983: Age and correlation of the Cambrian-Ordovician Bowers Supergroup, northern Victoria Land. In Oliver, R. L., James, P. R. \& Jago, J. B. (ed.) Antarctic earth science, 128-131. Canberra: Australian Acad. Sci.

Czarnocki, J. 1927: Kambri jego fauna w srodkowej czesci Gor Swietokrzyskich. Bull. Surv. geol. Poland 4, 189 only.

Dawes, P. R. 1971: The North Greenland fold belt and environs. Bull. geol. Soc. Denmark 20, 197-239.

Dawes, P. R. 1976: Precambrian to Tertiary of northern Greenland. In Escher, A. \& Watt, W. S. (ed.) Geology of Greenland, 248-303. Copenhagen: Geol. Survey Greenland.

Dawes, P. R. \& Soper, N. J. 1973: Pre-Quaternary history of North Greenland. In Pitcher, M. G. (ed.) Arctic geology. Mem. Am. Assoc. petrol. Geol. 19, 117-134.

Dawson, J. W. 1868: Acadian geology. The geological structure, organic remains, and mineral resources of Nova Scotia, New Brunswick, and Prince Edward Island, 2nd ed., 694 pp. London: MacMillan.

Deiss, C. 1939: Cambrian stratigraphy and trilobites of northwestern Montana. Spec. Pap. geol. Soc. Am. 18, 135 pp.

Demokidov, K. K. \& Lazarenko, N. P. 1964: [Stratigraphy of the upper Precambrian and Cambrian and Lower Cambrian trilobites from the northern part of the middle Siberia and islands of Soviet Arctic]. Trudy Nauchno-Issled. Inst. geol. Arktiki, Gos. geol. Komitet SSSR 137, 286 pp. [In Russian.]

Egorova, L. I. et al. 1960: In Khalfina, L. L. (ed.) [Palaeozoic biostratigraphy of the Sayano-Altay Mountain region]. Trudy Sib. Nauchno.-Issled. Inst. Geol. Geof. mineral. Syr. (SNIIGGIMS) 19, 497 pp. [In Russian.]

Fletcher, T. P., Higgins, A. K. \& Peel, J. S. 1988: A BaltoScandian Middle Cambrian fauna from Peary Land, North Greenland. Rapp. Gronlands geol. Unders. 137, 118.

Fortey, R. A. 1985: Pelagic trilobites as an example of deducing the life habits of extinct arthropods. Trans. R. Soc. Edinburgh 76, 219-230.

Fortey, R. A. 1990: Ontogeny, hypostome attachment and trilobite classification. Palaeontology 33, 529-576.
Fritz, W. H. 1972: Lower Cambrian trilobites from the Sekwi Formation type section, Mackenzie Mountains, northwestern Canada. Bull. geol. Surv. Canada 212, 90 pp.

Grabau, A. W. \& Shimer, H. W. 1910: North American index fossils, 853 pp. New York: A. G. Seiler \& Co.

Gregory, J. W. 1903: The Heathcotian: a pre-Ordovician series and its distribution. Proc. R. Soc. Victoria, n. s., 15(2).

Grönwall, K. A. 1902: Bornholms Paradoxideslag og deres fauna. Danm. geol. Unders. (Ser. 2), 13, $230 \mathrm{pp.}$

Gupta, V. J. 1967: Cambrian trilobites from Zachaldor, Baramula district, Kashmir. Res. Bull. Punjab Univ. (n. s.) 18, 275-277.

Harrington, H. J., Moore, R. C. \& Stubblefield, C. J. 1959a: Morphological terms applied to Trilobita. In Moore, R. C. (ed.) Treatise on invertebrate paleontology, part $\mathrm{O}$, Arthropoda 1, O117-O126. Lawrence: Geol. Soc. Am. and Kansas Univ. Press.

Harrington, H. J. et al. 1959b: Systematic descriptions. In Moore, R. C. (ed.) Treatise on invertebrate paleontology, part O, Arthropoda 1, O170-O540. Lawrence: Geol. Soc. Am. and Kansas Univ. Press.

Hawle, I. \& Corda, A. J. C. 1847: Prodom einer Monographie der böhemischen Trilobiten. Abh. K. böhem. Ges. Wiss. 5, 176 pp.

Henningsmoen, G. 1957: The trilobite family Olenidae. $S k r$. norske Vidensk-Akad. Mat.-naturv. K1. 1, 303 pp.

Hicks, H. 1872: On some undescribed fossils from the Menevian Group. Q. Jl geol. Soc. London 28, 173-185.

Higgins, A. K., Friderichsen, J. D. \& Soper, N. J. 1981: The North Greenland fold belt between central Johannes V. Jensen Land and eastern Nansen Land. Rapp. Gronlands geol. Unders. 106, 35-45.

Higgins, A. K., Ineson, J. R., Peel, J. S., Surlyk, F. \& Sønderholm, M. 1991: Lower Palaeozoic Franklinian Basin of North Greenland. Bull. Grønlands geol. Unders. 160, 71-139.

Hofmann, H. J. \& Parsley, R. L. 1966: Antennae of Ogygopsis. J. Paleont. 40, 209-211.

Holm, G. \& Westergård, A. H. 1930: A Middle Cambrian fauna from Bennett Island. Mem. Acad. Sci. l'URSS 21(8), 1-25.

Howell, B. F. 1925: The faunas of the Cambrian Paradoxides beds at Manuels, Newfoundland. Bulls Am. Paleont. 11(43), $140 \mathrm{pp}$.

Howell, B. F. 1932: Two new Cambrian trilobites from Vermont. Bull. Wagner Free Inst. Sci. 7, 4-8.

Howell, B. F. 1933: The classification of the trilobite family, Centropleurinae. Meddr Dansk Geol. Foren. 8, 215-219.

Howell, B. F. 1937: Cambrian Centropleura vermontensis fauna of northwestern Vermont. Bull. geol. Soc. Am. 48, 11471210.

Howell, B. F. 1943: Faunas of the Cambrian Cloud Rapids and Traytown Pond formations of northern Newfoundland. $\mathrm{J}$. $\mathrm{Pa}$ leont. 17, 236-247.

Hupé, P. 1953: Classe des trilobites. In Piveteau, J. (ed.) Traité de paléontologie 3, 44-246. Paris: Masson et Cie.

Hupé, P. 1955: Classification des trilobites. Annales Paléont. 41, 91-325.

Hutchinson, R. D. 1952: Middle Cambrian of the Atlantic realm in eastern Gaspé. Am. J. Sci. 250, 275-280. 
Hutchinson, R. D. 1962: Cambrian stratigraphy and trilobite faunas of southeastern Newfoundland. Bull. geol. Surv. Canada 88, $156 \mathrm{pp}$

Illing, V. C. 1916 [dated 1915]: Paradoxidian fauna of the Stockingford Shales. Q. Jl geol. Soc. London 71, 386-415.

Ineson, J. R. 1980: Carbonate debris flows in the Cambrian of south-west Peary Land, eastern North Greenland. Rapp. Gronlands geol. Unders. 99, 43-49.

Ineson, J. R. 1985: The stratigraphy and sedimentology of the Bronlund Fjord and Tavsens Iskappe groups (Cambrian) of Peary Land, eastern North Greenland. Unpublished Ph.D. thesis, Univ. Keele, 310 pp.

Ineson, J. R. 1988: Lithostratigraphy and depositional setting of the Holm Dal Formation (Middle Cambrian), central North Greenland. Meddr Gronland, Geosci. 20, 9-21.

Ineson, J. R. \& Peel, J. S. 1980: Cambrian stratigraphy in Peary Land, eastern North Greenland. Rapp. Gronlands geol. Unders. 99, 33-42.

Ineson, J. R. \& Peel, J. S. 1987: Cambrian platform - outer shelf relationships in the Nordenskiöld Fjord region, central North Greenland. Rapp. Gronlands geol. Unders. 133, 13-26.

Ineson, J. R. \& Peel, J. S. unpublished: Cambrian shelf stratigraphy of the Peary Land region, central North Greenland. Manuscript for Grønlands Geologiske Undersøgelse.

Ineson, J. R., Surlyk, F., Higgins, A. K. \& Peel, J. S. 1994: Slope apron and deep shelf sediments of the Brønlund Fjord and Tavsens Iskappe Groups (Lower Cambrian - Lower Ordovician) in North Greenland: stratigraphy, facies and depositional setting. Bull. Gronlands geol. Unders. 169 (this volume).

International Commission on Zoological Nomenclature. 1985: International code of zoological nomenclature. Third edition, 338 pp. London: Internatl Trust Zool. Nomen.

Ivshin, N. K. 1953: [Middle Cambrian trilobites of Kazakhstan, part 1]. Akad. Nauk Kazakh. SSR, Alma-Ata, 226 pp. [In Russian.]

Jago, J. B. 1972a: Biostratigraphic and taxonomic studies of some Tasmanian Cambrian trilobites. Unpublished Ph.D. dissertation, Univ. Adelaide, 448 pp.

Jago, J. B. 1972b: Two new Cambrian trilobites from Tasmania. Palaeontology 15, 226-237.

Jago, J. B. 1990: Cambrian faunas in the terranes of the southwestern Pacific part of Gondwana. Geol. Soc. Austral. Abstr. 25, 42-43.

Jell, P. A. 1970: Pagetia ocellata, a new Cambrian trilobite from northwestern Queensland. Mem. Queensland Mus. 15, 303313.

Jell, P. A. 1975: Australian Middle Cambrian eodiscoids with a review of the superfamily. Palaeontographica A 150, 1-97.

Jell, P. A. 1978: Trilobite respiration and genal caeca. Alcheringa 2, 251-260.

Jell, P. A. 1990: Trilobita. In Bengtson, S., Conway Morris, S., Cooper, B. J., Jell, P. A., \& Runnegar, B. 'N. (ed.) Early Cambrian fossils from South Australia. Mem. Assoc Australas. Palaeontol. 9, 257-322.

Keppie, J. D. 1989: Northern Appalachian terranes and their accretionary history. In Dallmeyer, R. D. (ed.) Terranes in the
circum-Atlantic orogens. Spec. Pap. geol. Soc. Am. 230, 159 192.

Kobayashi, T. 1935: The Cambro-Ordovician formations and faunas of South Chosen. Palaeontology. Part III. Cambrian faunas of South Chosen with a special study on the Cambrian trilobite genera and families. J. Fac. Sci., Tokyo Univ. 4(2), 49-344

Kobayashi, T. 1942a: On the Dolichometopinae. J. Fac. Sci., Tokyo Univ. 6(10), 141-206.

Kobayashi, T. 1942b: Miscellaneous notes on the CambroOrdovician Geology and Palaeontology VII: An occurrence of dolichometopids in South Chôsen with a summary note on the classification of the Dolichometopinae. J. geol. Soc. Japan 49, 211-218 (Trans. palaeont. Soc. Japan 161, 468-475).

Kobayashi, T. 1943a: Brief notes on the eodiscids I, their classification with a description of a new species and a new variety. Proc. Imp. Acad. Tokyo 19, 37-42.

Kobayashi, T. 1943b: Brief notes on the eodiscids II, phylogeny of the Dawsonidea. Proc. Imp. Acad. Tokyo 19, 43-47.

Kobayashi, T. 1944: On the eodiscids. Tokyo Imp. Univ., Fac. Sci., sec. 2(1), 7, 1-74.

Kobayashi, T. 1962: The Cambro-Ordovician formations and faunas of South Korea Part IX: Palaeontology VIII: The Machari fauna. J. Fac. Sci., Tokyo Univ. 14(1), 152 pp.

Korobov, M. N. 1973: [Trilobites of the family Conocoryphidae and their importance for the stratigraphy of Cambrian deposits]. Trudy Akad. Nauk SSSR geol. Inst. 211, 176 pp. [In Russian.]

Krashopeeva, P. S. 1958: [Archaeocyathan and archaeocyathantrilobite horizons of the Altai-Sayan region Cambrian]. $\mathrm{Ma}$ ter. Geol. zapad.-sib. Kraya 61, 105-111. [In Russian.]

Lake, P. 1907: A monograph of the British Cambrian trilobites, part 2. Monogr. Palaeontogr. Soc., London, 29-48.

Lake, P. 1931: A monograph of the British Cambrian trilobites, part 6. Monogr. Palaeontogr. Soc., London, 121-148.

Lake, P. 1934: A monograph of the British Cambrian trilobites, part 8. Monogr. Palaeontogr. Soc., London, 173-196.

Lake, P. 1938: A monograph of the British Cambrian trilobites, part 11. Monogr. Palaeontogr. Soc., London, 249-272.

Lake, P. 1940: A monograph of the British Cambrian trilobites, part 12. Monogr. Palaeontogr. Soc., London, 273-306.

Lazarenko, N. P. 1962: [New Lower Cambrian trilobites from the Soviet arctic]. Sb. statei po paleont. biostrat. 29, $29-78$. [In Russian.]

Lazarenko, N. P. 1965: [Some new Middle Cambrian trilobites from the north of central Siberia]. Uch. Zap., Paleont. bistrait. 7, 14-36. [In Russian.]

Lermontova, E. V. 1940: [Arthropoda]. In Vologdin, A. (ed.) [Atlas of the leading forms of the fossil faunas of the USSR.] Vol. 1, 112-157. Moscow, Leningrad: Gos. Izd. Geol. Lit. [In Russian.]

Lermontova, E. V. 1951: [Middle Cambrian trilobites and gastropods from Shody-Mir]. Trudy Vses. Nauchno-Issled. Geol. Inst. (VSEGEI). 37 pp. [In Russian.]

Lesley, J. P. 1889: A dictionary of the fossils of Pennsylvania and neighboring states named in the reports and catalogues of the Survey. Geol. Surv. Pennsylv. Rept P4, 1283 pp. 
Lindström, G. 1901: Researches on the visual organs of the trilobites. K. Svenska Vetensk.-Akad. Handl. 34, 87 pp.

Linnarsson, J. G. O. 1879: Om faunen i kalken med Conocoryphe exsulans ('Coronatuskalken'). Sveriges geol. Unders. ser. C 35, 1-35.

Linnarsson, J. G. O. 1883: De undre paradoxideslagren vid Andrarum. Sver. geol. Unders. ser. C 54 (1882), 1-40.

Lochman, C. 1947: Analysis and revision of eleven Lower Cambrian trilobite genera. J. Paleont. 21, 59-71.

Lochman, C. 1956: The evolution of some Upper Cambrian and Lower Ordovician trilobite families. J. Paleont. 30, 445-462.

Matthew, G. F. 1886: Illustrations of the fauna of the St. John's Group. Trans. R. Soc. Canada 4(3), 29 pp.

Matthew, G. F. 1887: Illustrations of the fauna of the St. John's Group no. IV - part I. Description of a new species of Paradoxides (Paradoxides regina). Part II. The smaller trilobites with eyes (Ptychoparidae and Ellipsocephalidae). Trans. R. Soc. Canada 5, 115-166.

Matthew, G. F. 1896: Faunas of the Paradoxides beds in eastern North America, no. 1. Trans. N. Y. Acad. Sci. 15, 192-247.

Matthew, G. F. 1897: Studies on Cambrian faunas. Trans. $R$. Soc. Canada, ser. 2, 3(4), 165-211.

Matthew, G. F. 1899: Studies on Cambrian faunas, no. 3; Upper Cambrian fauna of Mount Stephen, British Columbia. The trilobites and worms. Trans. R. Soc. Can. ser. 2, 5(4), 39-121.

McLaughlin, K. P. \& Enbysk, B. B. 1950: Middle Cambrian trilobites from Pend Oreille County, Washington. J. Paleont. 24, 466-471.

McNamara, K. J. 1986a: A guide to the nomenclature of heterochrony. J. Paleont. 60, 4-13.

McNamara, K. J. 1986b: The role of heterochrony in the evolution of Cambrian trilobites. Biol. Rev. 61, 121-156.

McNamara, K. J. \& Rudkin, D. M. 1984: Techniques of trilobite exuviation. Lethaia 17, 152-173.

Meek, F. B. 1870: Descriptions of fossils collected by the U.S. Geological Survey under the charge of Clarence King, esq. Proc. Acad. Sci. Philadelphia (2nd ser.) 14, 56-64.

Meek, F. B. 1873: Preliminary paleontological report, consisting of lists and descriptions of fossils, with remarks on the rocks in which they were found. U.S. geol. Surv. Terr. (Hayden), 6th Ann. Rept., 431-518.

Meek, F. B. 1877: Palèontology. U.S. geol. Expl. 40th Parallel (King) 4(2), 197 pp.

Miller, S. A. 1889: North American geology and paleontology for the use of amateurs, students, and scientists, $664 \mathrm{pp}$. Cincinnati: publ. by the author.

Miller, S. A. 1892: First appendix, 1892, 665-718. Cincinnati: publ. by the author.

Morris, S. F. 1988: A review of British trilobites, including a synoptic revision of Salter's monograph. Monogr. Palaeontogr. Soc. London, 316 pp.

Müller, K. J. \& Walossek, D. 1987: Morphology, ontogeny, and life habit of Agnostus pisiformis from the Upper Cambrian of Sweden. Fossils \& Strata 19, 124 pp.

Nelson, C. A. 1963: Stratigraphic range of Ogygopsis. J. Paleont. 37, 244-248.

Nicholas, T. C. 1916 [dated 1915]: On the trilobite fauna of the
Middle Cambrian of St. Tudwal's Peninsula. $Q$. $\mathrm{Jl}$ geol. Soc. London 71, 451-472.

Öpik, A. A. 1949: A Middle Cambrian trilobite from Victoria Centropleura neglecta n. sp. Mining Geol. Jour. 3, 55-58.

Öpik, A. A. 1961: The geology and palaeontology of the headwaters of the Burke River, Queensland. Bull. Bur. Miner. Resour. Australia 53, 249 pp.

Öpik, A. A. 1967: The Mindyallan fauna of north-western Queensland. Bull. Bur. Miner. Resour. Australia 74(1), 404 pp.; 74(2), 167 pp., 67 pls.

Öpik, A. A. 1970: Nepeid trilobites of the Middle Cambrian of northern Australia. Bull. Bur. Miner. Resour. Australia 113, $48 \mathrm{pp}$.

Öpik, A. A. 1975: Templetonian and Ordian xystridurid trilobites of Australia. Bull. Bur. Miner. Resour. Australia 121, 84 pp.

Öpik, A. A. 1979: Middle Cambrian agnostids: systematics and biostratigraphy. Bull. Bur. Miner. Resour. Australia 172(1), 188 pp.; 172(2), 67 pls.

Palmer, A. R. 1954: An appraisal of the Great Basin Middle Cambrian trilobite described before 1900. Prof. Pap. U.S. geol. Surv. 264D, 55-86.

Palmer, A. R. 1964: An unusual Lower Cambrian trilobite fauna from Nevada. Prof. Pap. U.S. geol. Surv. 483F, 1-13.

Palmer, A. R. 1966: New Cambrian fossils from Antarctica. Prof. Pap. U.S. geol. Surv. 550A, A95.

Palmer, A. R. 1968: Cambrian trilobites of east-central Alaska. Prof. Pap. U.S. geol. Surv. 559B, 1-115.

Palmer, A. R. 1974: Search for the Cambrian world. Am. Scient. 62, 216-224.

Palmer, A. R. \& Gatehouse, C. G. 1972: Early and Middle Cambrian trilobites from Antarctica. Prof. Pap. U.S. geol. Surv. 456D, 1-37.

Palmer, A. R. \& Halley, R. B. 1979: Physical stratigraphy and trilobite biostratigraphy of the Carrara Formation (Lower and Middle Cambrian) in the southern Great Basin. Prof. Pap. U.S. geol. Surv. 1047, 1-131.

Palmer, A. R. \& Peel, J. S. 1981: Dresbachian trilobites and stratigraphy of the Cass Fjord Formation, western North Greenland. Bull. Grønlands geol. Unders. 141, $46 \mathrm{pp}$.

Palmer, A: R. \& Stewart, J. S. 1968: A paradoxidid trilobite from Nevada. $J$. Paleont. 42, 177-179.

Peel, J. S. 1982: The Lower Paleozoic of Greenland. In Embry, A. F. \& Balkwill, H. R. (ed.) Arctic geology and geophysics. Mem. Can. Soc. petrol. Geol. 8, 309-330.

Peel, J. S. \& Christie, R. L. 1982: Cambrian-Ordovician platform stratigraphy: correlations around Kane basin. Meddr Grønland, Geosci. 8, 117-135.

Pokrovskaya, N. V. 1959: Trilobitovaya faunai stratigrafiya Kembriyiskikh otlozheniy Tuvy. Trudy geol. Inst. Leningr. 27, 1-198.

Poletaeva, O. K. \& Romanenko, E. V. 1970: Nekotorye trilobity srednego i pozdnego Kembriya Altaya. Paleont. Zhur. 1970 (2), 72-83. [English translation: Middle and late Cambrian trilobites of the Altay. Paleont. J. 4(2), 216-228.]

Pompeckj, J. F. 1896: Die fauna des Cambrium von Tejrovic und Skrej in Böhmen. Jahr. d. K. k. geol. Reichsanstalt 45, 495 614. 
Poulsen, C. 1927: The Cambrian, Ozarkian and Canadian faunas of northwest Greenland. Meddr Gronland 71(2), 233-343.

Poulsen, C. 1946: Notes on the Cambro-Ordovician fossils collected by the Oxford University Ellesmere Land expedition; 1934-35. Q. Jl geol. Soc. London 102, 299-337.

Poulsen, V. 1964: Contribution to the Lower and Middle Cambrian paleontology and stratigraphy of northwest Greenland. Meddr Grønland 164(6), 105 pp.

Poulsen, V. 1969: An Atlantic Middle Cambrian fauna from North Greenland. Lethaia 2, 1-14.

Rasetti, F. 1948a: Lower Cambrian trilobites from the conglomerates of Quebec (exclusive of the Ptychopariidea). J. Paleont. 22, 1-24.

Rasetti, F. 1948b: Middle Cambrian trilobites from the conglomerates of Quebec (exclusive of the Ptychopariidea). J. Paleont. 22, 315-339.

Rasetti, F. 1951: Middle Cambrian stratigraphy and faunas of the Canadian Rocky Mountains. Smithson. misc. Collns 116 (5), 277 pp.

Rasetti, F. 1952: Revision of the North American trilobites of the family Eodiscidae. J. Paleont. 26, 434-451.

Rasetti, F. 1955: Lower Cambrian ptychopariid trilobites from the conglomerates of Quebec. Smithson. misc. Collns 128(7), $35 \mathrm{pp}$.

Rasetti, F. 1965: Middle Cambrian trilobites of the Pleasant Hill Formation in central Pennsylvania. J. Paleont. 39, 10071014.

Rasetti, F. 1967: Lower and Middle Cambrian trilobite faunas from the Taconic sequence of New York. Smithson. misc. Collns 152(4), 111 pp.

Raymond, P. E. 1913: On the genera of the Eodiscidae. Ottawa Naturalist 27, 101-106.

Raymond, P. E. 1937: Upper Cambrian and Lower Ordovician Trilobita and Ostracoda from Vermont. Bull. geol. Soc. Am. 48, 1079-1146.

Raymond, P. E. \& Walcott, C. E. 1937: Subclass A. Trilobita Walch. Trilobites. In Eastman, C. R. (ed.) Text-book of palaeontology, adapted from the German of Karl A. von Zittel, Vol. I. 2nd edition, 692-729. London: MacMillan \& Co.

Reed, F. R. C. 1898: Blind trilobites. Geol. Mag. (4), 5, 439447, 493-506, 552-560.

Resser, C. E. 1935: Nomenclature of some Cambrian trilobites. Smithson. misc. Collns 93(5), 46 pp.

Resser, C. E. 1936: Second contribution to nomenclature of Cambrian trilobites. Smithson. misc. Collns 95(4), 29 pp.

Resser, C. E. 1937a: New species of Cambrian trilobites of the family Conocoryphidae. J. Paleont. 11, 39-42.

Resser, C. E. 1937b: Third contribution to nomenclature of Cambrian trilobites. Smithson. misc. Collns 95(22), 29 pp.

Resser, C. E. 1938: Cambrian System (restricted) of the southern Appalachians. Spec. Pap. geol. Soc. Am. 15, 140 pp.

Resser, C. E. 1939a: The Spence Shale and its fauna. Smithson. misc. Collns 97(12), 29 pp.

Resser, C. E. 1939b: The Ptarmigania strata of the northern Wasatch Mountains. Smithson. misc. Collns 98(24), $72 \mathrm{pp}$.

Resser, C. E. 1942: New Upper Cambrian trilobites. Smithson. misc. Collns 103(5), 136 pp.

Resser. C. E. 1945: Cambrian fossils of the Grand Canyon In
McKee, E. D. \& Resser, C. E. (ed.) Cambrian history of the Grand Canyon region, 169-220. Washington: Carnegie Inst.

Reyment, R. A. 1980: Material in the Uppsala collections described by N. P. Angelin (1854) in his 'Palaeontologia Scandinavica', P. I. 'Crustacea formationis transitionis', Lipsiae. Lund. De rebus in Palaeontologico Museo Upsaliensi collectis. Illustrated catalogue of the type collections of the Palaeontological Museum of the University of Uppsala 4, 5-8.

Richter, R. \& Richter, E. 1948: Studien im Paläozoikum der Mittelmeer-Länder, 8, Zur Frage des Unter-Kambriums in Nordost-Spanien. Senckenbergiana 29, 23-39.

Robison, R. A. 1964: Late Middle Cambrian faunas from western Utah. J. Paleont. 38, 510-566.

Robison, R. A. 1971: Additional Middle Cambrian trilobites from the Wheeler Shale of Utah. J. Paleont. 45, 796-804.

Robison, R. A. 1972: Mode of life of agnostid trilobites. Proc. 24 Int. geol. Congr., Montreal 7, 33-40.

Robison, R. A. 1976: Middle Cambrian trilobite biostratigraphy of the Great Basin. Brigham Young Univ. geol. Stud. 23(2), 93-109.

Robison, R. A. 1984: Cambrian Agnostida of North America and Greenland; part I, Ptychagnostidae. Paleontol. Contr. Univ. Kansas Pap. 109, 59 pp.

Robison, R. A. 1987: Class Trilobita. In Boardman, R. S., Cheetham, A. H. \& Rowell, A. J. (ed.) Fossil invertebrates, 221-241. Palo Alto, California: Blackwell.

Robison, R. A. 1988: Trilobites of the Holm Dal Formation (late Middle Cambrian), central North Greenland. Meddr Grønland, Geosci. 20, 23-103.

Robison, R. A. 1994: Agnostoid trilobites from the Henson Gletscher and Kap Stanton formations (Middle Cambrian), North Greenland. Bull. Gronlands geol. Unders. 169 (this volume).

Robison, R. A. \& Babcock, L. E. 1990: Biogeography of Middle Cambrian trilobites from North Greenland: implications for terrane analysis. 3 Int. Symp. Cambrian System, Novosibirsk, USSR, Abstracts, 151.

Robison, R. A. \& Campbell, D. P. 1974: A Cambrian corynexochid trilobite with only two thoracic segments. Lethaia 7 , 273-282.

Romanenko, Y. V. 1985: [Trilobites from the Middle-Upper Cambrian boundary beds of Altai]. Paleont. Zhur. 19(4), 54-63. [In Russian.] [English translation: Paleont. J. 19(4), 64-74.]

Rominger, C. L. 1887: Description of primordial fossils from Mt. Stephens, NW Territory of Canada. Acad. Nat. Sci. Philadelphia, Proc. for 1887, 12-19.

Rosova, A. V. 1964: [Biostratigraphy and description of trilobites of the Middle and Upper Cambrian of the northwestern Siberian platform]. Inst. Geol. Geofiz., Akad. Nauk SSSR Sibir. Otdel., 148 pp. [In Russian.]

Rudkin, D. M. 1979: Healed injuries in Ogygopsis klotzi (Trilobita) from the Middle Cambrian of British Columbia. Occ. Pap. Royal Ontario Mus. Life Sci. 32, 8 pp.

Rusconi, C. 1954: Trilobitas Cámbricos de la Quebradita Oblicua, sud del Cerro Aspero. Revta Mus. Hist. nat, Mendoza 7, 3-59.

Rushton, A. W. A. 1966: The Cambrian trilobites from the 
Purley shales of Warwickshire. Monogr. Palaeontogr. Soc. London 120, $55 \mathrm{pp}$.

Rushton, A. W. A. 1974: The Cambrian of England and Wales. In Holland, C. H. (ed.) Lower Paleozoic rocks of the world 2, Cambrian of the British Isles, Norden and Spitsbergen, 43121. London: John Wiley \& Sons.

Salter, J. W. 1864: On some new fossils from the Lingula-flags of Wales. Q. Jl Geol. soc. London 20, 233-241.

Salter, J. W. 1866: A monograph of British trilobites. Monogr. Palaeontogr. Soc., London, 129-176.

Scotese, C. R. 1987: Phanerozoic plate tectonic reconstructions. Paleoceanogr. map. Proj., Univ. Texas, Inst. Geophys., Tech. Rept 40, $54 \mathrm{pp}$

Scotese, C. R., Bambach, R. K., Barton, C., Van der Voo, R. \& Ziegler, A. M. 1979: Paleozoic base maps. J. Geol. 87, 217277.

Scotese, C. R. \& McKerrow, W. S. 1990: Revised world maps and introduction. In McKerrow, W. S. \& Scotese, C. R. (ed.) Palaeozoic palaeogeography and biogeography. Mem. geol. Soc. London 12, 1-21.

Shah, S. K. \& Sudan, C. S. 1982: Bolaspidella from the Cambrian of Kashmir and its stratigraphic significance. J. geol. Soc. India 23, 236-245.

Shaw, A. B. 1962: Paleontology of northwestern Vermont. IX. Fauna of the Monkton Quartzite. J. Paleont. 36, 322-345.

Shaw, A. B. 1966: Paleontology of northwestern Vermont. XI. Fossils from the Middle Cambrian St. Albans Shale. J. Paleont. 40, 843-858.

Shimer, H. W. \& Shrock, R. R. 1944: Index fossils of North America, 837 pp. New York: John Wiley \& Sons.

Snajdr, M. 1957: O novych trilobitech z ceskeho Kambria. Vestnik Ustred. ustav geolog. 32, 235-244.

Šnajdr, M. 1958: Trilobiti ceskeho stredního Kambria. Rozpravy Ustred. ustav geolog. 24, $280 \mathrm{pp}$.

Soper, N. J. \& Higgins, A. K. 1985: Thin-skinned structures at the basin-shelf transition in North Greenland. Rapp. Gronlands geol. Unders. 126, 87-94.

Stewart, J. H. \& Palmer, A. R. 1967: Callaghan window - a newly discovered part of the Roberts thrust, Toiyabe Range, Lander County, Nevada. Prof. Pap. U.S. geol. Surv. 575D, D56-D63.

Stoyanow, A. 1958: Sonoraspis and Albertella in the Inyo Mountains, California. Bull. geol. Soc. Am. 69, 347-352.

Strand, T. 1929: The Cambrian beds of the Mjøsen district in Norway. Norsk geol. Tidsskr. 10, 308-365.

Surlyk, F. 1991: Tectonostratigraphy of North Greenland. Bull. Gronlands geol. Unders. 160, 25-47.

Surlyk, F. \& Ineson J. R. 1987: Aspects of Franklinian shelf, slope and trough evolution and stratigraphy in North Greenland. Rapp. Grønlands geol. Unders. 133, 41-58.

Suvorova, N. P. 1960: [Cambrian trilobites of eastern Siberian Platform; Olenellidae - Granulariidae]. Trudy Paleont. Cheskogo Inst. 84(2), 1-230. [In Russian.]

Suvorova, N. P. 1964: [Trilobites Corynexochidae and their historical development]. Trudy Paleont. Inst. 103, 319 pp. [In Russian.]

Swofford, D. L. 1989: PAUP: phylogenetic analysis using parsi- mony, version 3.0. 35 pp. Computer program distributed by the Illinois Natural History Survey, Champaign, Illinois.

Talent, J. A. 1990: The peripatetic fossils: part 5. Nature 343, 405-406.

Termier, G. \& Termier, H. 1950: Paléontologie Marocaine II: Invertébrés de l'ère primaire. Fascicule IV: Annélides, arthropodes, échinodermes, conularides et graptolithes. Maroc, Division des Mines et de la Service Géologique, Notes et Mémoires 79, $279 \mathrm{pp}$.

Thorslund, P. 1949: Notes on Kootenia n. sp. and associated Paradoxides species from the Lower Middle Cambrian of Jemtland, Sweden. Sver. geol. Unders. C 510, 3-7.

Vodges, A. W. 1925: Paleozoic Crustacea. The publications and notes on genera and species during the past twenty years, 1895-1917. Trans. San Diego soc. Nat. Hist. 3(1), 1-141.

Walcott, C. D. 1884: The paleontology of the Eureka district, Nevada. Monogr. U.S. geol. Surv. 8, 298 pp.

Walcott, C. D. 1886: Second contribution to the studies on the Cambrian faunas of North America. Bull. U.S. geol. Surv. 30, $369 \mathrm{pp}$.

Walcott, C. D. 1888: Cambrian fossils from Mount Stephen, northwest territory of Canada. Am. J. Sci. 3 ser., 36, 163-166.

Walcott, C. D. 1889: Description of new genera and species of fossils from the Middle Cambrian. Proc. U.S. Natl Mus. 11 (1888), 441-446.

Walcott, C. D. 1908: Mount Stephen rocks and fossils. Canadian Alpine J. 1, 232-248.

Walcott, C. D. 1913: New Lower Cambrian subfauna. Smithson. misc. Collns 57(11), 309-326.

Walcott, C. D. 1916: Cambrian geology and paleontology III: No. 5. Cambrian trilobites. Smithson. misc. Collns 64(5), 301-457.

Walcott, C. D. 1917: Fauna of the Mount Whyte Formation. Smithson. misc. Collns 67(3), 61-114.

Walcott, C. D. 1918: Cambrian geology and paleontology IV, No. 4. Appendages of trilobites. Smithson. misc. Collns 67(4), 115-216.

Walcott, C. D. 1924: Cambrian geology and paleontology V: No. 2. Cambrian and lower Ozarkian trilobites. Smithson. misc. Collns 75(2), 53-60.

Walcott, C. D. 1925: Cambrian geology and paleontology V: No. 3. Cambrian and Ozarkian trilobites. Smithson. misc. Collns 75(3), 61-146.

Westergård, A. H. 1946: Agnostida of the Middle Cambrian of Sweden. Sver. geol. Unders. C 477, 141 pp.

Westergård, A. H. 1949: Opsidiscus, new name replacing Aulacodiscus Westergård, 1946. Geol. Fören. Stockh. Förhandl. 71, 606 .

Westergård, A. H. 1950: Non-agnostidean trilobites of the Middle Cambrian of Sweden II. Sver. geol. Unders. C 511, 57 pp.

Westergård, A. H. 1953: Non-agnostidean trilobites of the Middle Cambrian of Sweden III. Sver. geol. Unders. C 526, 59 pp.

Whiteaves, J. F. 1878: On some primordial fossils from southeastern Newfoundland. Am. J. Sci. 16, 224-226.

Whitehouse, F. W. 1939: The Cambrian faunas of north-eastern Australia, Part 3. Mem. Queensland Mus. N.S. 1, 179-282.

Wiley, E. O. 1979: An annotated Linnaean hierarchy, with 
comments on natural taxa and competing systems. Sys. Zool. 28, 308-337.

Woodward, H. 1902: The Canadian Rockies. Part I: On a collection of Middle Cambrian fossils obtained by Edward Whymper, from Mt. Stephen, British Columbia. Geol. Mag. (4), 9 , 502-505.

Yanishevski, M. E. 1950: Dryevyyeishii trilovit nishnyecambrian Sinyei Gkini. Vopr. Paleont. Leningrad Univ. 1, 32-40. [In Russian.]

Xiang Liwen \& Zhang Tairong. 1985: [Systematic descriptions of trilobites. In Stratigraphy and trilobite faunas of the Cambrian in the western part of the northern Tian Shan, Xinjiang.]
Peopl. Republ. China, Minist. Geol. Miner. Resour., Geol. Mem. ser. 2(4), 64-243. [In Chinese with English summary.] Young, G. A. \& Ludvigsen, R. 1989: Mid-Cambrian trilobites from the lowest part of the Cow Head Group, western Newfoundland. Bull. geol. Surv. Canada 392, 49 pp.

Zhang, Xi-guang. 1989: Ontogeny of an Early Cambrian codiscoid trilobite from Henan, China. Lethaia 22, 13-29.

Zhuravleva, I. T. et al. 1970: [Concerning knowledge of the Early Cambrian of the southern Tien Shan]. Trest. 'Tashkentgeologiya' Kompl. geol. poiskobaya eksped., Izd. FAN Uzbeskoy SSR. $53 \mathrm{pp}$. 